\title{
Phenolic cross-links: building and de-constructing the plant cell wall
}

Mnich, Ewelina; Bjarnholt, Nanna; Eudes, Aymerick; Harholt, Jesper; Holland, Claire; Jørgensen, Bodil; Larsen, Flemming Hofmann; Liu, Ming; Manat, Renil; Meyer, Anne S.

Total number of authors:

19

Published in:

Natural Product Reports

Link to article, DOI:

10.1039/c9np00028c

Publication date:

2020

Document Version

Peer reviewed version

Link back to DTU Orbit

Citation (APA):

Mnich, E., Bjarnholt, N., Eudes, A., Harholt, J., Holland, C., Jørgensen, B., Larsen, F. H., Liu, M., Manat, R., Meyer, A. S., Mikkelsen, J. D., Motawia, M. S., Muschiol, J., Møller, B. L., Møller, S. R., Perzon, A., Petersen, B. L., Ravn, J. L., \& Ulvskov, P. (2020). Phenolic cross-links: building and de-constructing the plant cell wall. Natural Product Reports, 37(7), 919-961. https://doi.org/10.1039/c9np00028c

\section{General rights}

Copyright and moral rights for the publications made accessible in the public portal are retained by the authors and/or other copyright owners and it is a condition of accessing publications that users recognise and abide by the legal requirements associated with these rights.

- Users may download and print one copy of any publication from the public portal for the purpose of private study or research.

- You may not further distribute the material or use it for any profit-making activity or commercial gain

- You may freely distribute the URL identifying the publication in the public portal 


\section{c)}

\section{Natural Product Reports}

\section{Phenolic cross-links: Building and de-constructing of the plant cell wall}

\begin{tabular}{|c|c|}
\hline Journal: & Natural Product Reports \\
\hline Manuscript ID & NP-REV-05-2019-000028.R2 \\
\hline Article Type: & Review Article \\
\hline $\begin{array}{r}\text { Date Submitted by the } \\
\text { Author: }\end{array}$ & 13-Dec-2019 \\
\hline Complete List of Authors: & $\begin{array}{l}\text { Mnich, Ewelina; Kobenhavns Universitet Det Natur- og Biovidenskabelige } \\
\text { Fakultet, Plant and Environmental Sciences } \\
\text { Bjarnholt, Nanna; Kobenhavns Universitet Det Natur- og } \\
\text { Biovidenskabelige Fakultet, Plant and Environmental Sciences } \\
\text { Eudes, Aymerick; Joint Bioenergy Institute, Emeryville, CA, } \\
\text { Harholt, Jesper; Carlsberg Group R\&D, Carlsberg Research Laboratory } \\
\text { Holland, Claire; Kobenhavns Universitet Det Natur- og Biovidenskabelige } \\
\text { Fakultet, Plant and Environmental Sciences } \\
\text { Jørgensen, Bodil; Kobenhavns Universitet Det Natur- og } \\
\text { Biovidenskabelige Fakultet, Department for Plant and Environmental } \\
\text { Sciences } \\
\text { Larsen, Flemming; University of Copenhagen, Department of Food } \\
\text { Science } \\
\text { Liu, Ming; Technical University of Denmark, Chemical and Biochemical } \\
\text { Engineering } \\
\text { Renil, Manat; Carlsberg Group R\&D, Carlsberg Research Laboratory } \\
\text { Meyer, Anne; Technical University of Denmark, Department of Chemical } \\
\text { and Biochemical Engineering } \\
\text { Mikkelsen, Jørn; Technical University of Denmark, Center for BioProcess } \\
\text { Engineering, Dept. of Chemical and Biochemical Engineernig } \\
\text { Motawia, Mohammed Saddik; University of Copenhagen, Department of } \\
\text { Plant and Environmental Sciences } \\
\text { Muschiol, Jan; Technical Univeristy of Denmark, Dept. of Chemical and } \\
\text { Biochemical Engineering } \\
\text { Møller, Birger; Kobenhavns Universitet Det Natur- og Biovidenskabelige } \\
\text { Fakultet, Plant and Environmental Sciences } \\
\text { Möller, Svenning; Kobenhavns Universitet Det Natur- og } \\
\text { Biovidenskabelige Fakultet, Plant and Environmental Sciences } \\
\text { Perzon, Alixander; Kobenhavns Universitet Det Natur- og } \\
\text { Biovidenskabelige Fakultet, Plant and Environmental Sciences } \\
\text { Petersen, Bent Larsen; Kobenhavns Universitet Det Natur- og } \\
\text { Biovidenskabelige Fakultet, Plant and Environmental Sciences; } \\
\text { Kobenhavns Universitet Biologisk Institut, } \\
\text { Ravn, Jonas; Novozymes A/S, Feed Applications } \\
\text { Ulvskov, Peter; Kobenhavns Universitet Det Natur- og Biovidenskabelige } \\
\text { Fakultet, Plant and Environmental Sciences }\end{array}$ \\
\hline
\end{tabular}




\section{SCHOLARONE ${ }^{\text {m }}$ Manuscripts}




\section{Phenolic cross-links: Building and de-constructing the plant cell wall}

Ewelina Mnich ${ }^{1}$, Nanna Bjarnholt ${ }^{1}$, Aymerick Eudes ${ }^{2,3}$, Jesper Harholt $^{4}$, Claire Holland ${ }^{1}$, Bodil Jørgensen ${ }^{1}$, Flemming Hofmann Larsen ${ }^{5}$, Ming Liu ${ }^{6}$, Renil Manat ${ }^{4}$, Anne S. Meyer ${ }^{6}$, Jørn Dalgaard Mikkelsen $^{6}$, Mohammed Saddik Motawia ${ }^{1}$, Jan Muschiol ${ }^{6}$, Birger Lindberg Møller ${ }^{1}$, Svenning Rune Møller ${ }^{1}$ Alixander Perzon ${ }^{1}$, Bent Larsen Petersen ${ }^{1}$, Jonas Laukkonen Ravn ${ }^{7}$, Peter Ulvskov ${ }^{1}$

1) Department of Plant and Environmental Sciences, University of Copenhagen

2) Joint BioEnergy Institute, EmeryStation East, 5885 Hollis St, 4th Floor, Emeryville, CA 94608, USA

3) Environmental Genomics and Systems Biology Division, Lawrence Berkeley National Laboratory, 1 Cyclotron Road, Berkeley, CA 94720, USA

4) Carlsberg Research Laboratory, Copenhagen Denmark

5) Department of Food Science, University of Copenhagen

6) Dept of Biotechnology and Biomedicine, Technical University of Denmark

7) Novozymes A/S, Bagsværd Denmark

\section{Introduction}

A cell wall built mainly from polysaccharides is a distinctive feature of Streptophyta, the branch of the green plant lineage that includes terrestrial plants. Microfibrillar cellulose forms a composite in combination with a very complex set of other polysaccharides, providing a matrix for the embedding of insoluble microfibrils superimposed on a covalent network of phenolic polymers. The polysaccharide composite is a dynamic structure, subject to turnover while the cell is expanding, whereas the plant cell has very limited ability to modify the phenolic network. Deposition of the phenolic network is a phenomenon that occurs during wall maturation - when cell expansion is complete - culminating in some cell types with deposition of a secondary wall on the inside of the primary wall. In cells that differentiate into vessel elements, deposition of the phenolic network may in fact run to completion post-mortem ${ }^{1}$, i.e. lignification of the wall progresses after the cell 
nucleus has disintegrated relying only on $\mathrm{H}_{2} \mathrm{O}_{2}$ and monolignols from living neighborings cells.

Lignin is the major constituent of the phenolic network and is composed entirely of phenolics. Lignin polymerization could comprise and may even be nucleated by phenolic substituents on polysaccharides and tyrosine residues of a class of cell wall structural glycoproteins known as extensins, as shall be discussed in this review. The occurrence of phenolic esters on plant polysaccharides was recently reviewed by Harris and Trethewey².

Polymerization of phenolics in the wall is mediated by reactive oxygen species in the apoplast. The enzymes involved, the types of reactions and the chemical bonds formed are the unifying principle for which we use the term cross-link when the result truly is cross-linking of two polymeric entities and phenolic inter-unit linkages when a similar chemical bond is formed between phenolic entities in intra-chain links and as part of monolignol polymerization, in vivo or in vitro.

The fact that some reactive oxygen species play a role in wall loosening during growth while others mediate cross-linking, and hence retard cell expansion, complicates the unraveling of the biochemical control of these processes ${ }^{3}$. In addition, the expansive gene families encoding peroxidases ${ }^{4}$ and laccases, which catalyze cross-linking, pose a challenge when aiming to assign specific roles to individual enzymes.

The oxidative regime in the apoplast is brought about by several paths involving, for example, amine oxidases, oxalate oxidase, and $\mathrm{NAD}(\mathrm{P}) \mathrm{H}$ oxidase. The importance 
of different enzyme classes differs between plant families and it is possible that different oxidative systems arose via convergent evolution ${ }^{5}$. Generalizations and inferences from one plant species to the next should thus be made with caution. The present review focuses on the phenolic linkages within the plant cell wall, their biological function, and how to make and break them. With respect to the application of this knowledge, phenolic cross-links and inter-unit linkages may be both a blessing and a nuisance. Enzyme-mediated cross-linking may be used to bio-engineer new composites and other "green" materials. Near the end of this review, we will cover the use of cross-linking enzymes for the manufacture of fiber cell composites, nanocellulose materials and hydrogels for use in biomedical materials for example. On the other hand, lignification of secondary cell walls is the major reason for the recalcitrance of biomass to disassembly. Nature-inspired approaches to facilitate cleavage of phenolic cross-links may allow the most challenging impediments to a global move towards a bio-based society based on second generation biofuels to be overcome. This review is concluded with a perspective on these matters.

\section{Occurrence and physiological function of polymers involved in phenolic cross- linking \\ 2.1 Occurrence and physiological function of lignin}

Lignin is a cell wall polymer of randomly linked hydroxycinnamyl alcohols (or monolignols), which are principally p-coumaryl alcohol, coniferyl alcohol, and sinapyl alcohol. The polymerization of these $\mathrm{C} 6-\mathrm{C} 3$ alcohols results in the formation of the $\mathrm{H}, \mathrm{G}$, and $\mathrm{S}$ units of lignin, respectively ${ }^{6}$ (Figure 1). Lignin is found in the cell 
walls of all vascular plants (tracheophytes) where it plays an essential role in growth and development. Lignin contributed to the emergence of tracheophytes by imparting the water-conductive vascular elements with structural rigidity and hydrophobicity. The hydrophobic nature of lignin is essential for it to confer strength to secondary walls ${ }^{7}$ while the unwettable property of lignin is indispensable for the transport and distribution of water in tracheary elements of terrestrial plants ${ }^{8}$. As a key structural element of the cell wall, lignin also constitutes a defense barrier against herbivores and in the root endodermis it is a barrier to soil-borne pathogens ${ }^{9}$. These features enabled vascular plants to reach much larger physical dimensions than their non-lignified bryophyte ancestors ${ }^{10}$. Material strength has been investigated in transgenic trees that have a modified lignin content or structure $^{11,12}$. In addition, the role of lignin in lodging resistance in cereals has been debated for more than a century ${ }^{13,14}$. What is probably less obvious is that lignin influences the microbial populations in both the rhizosphere and the endosphere, as observed in studies of transformants modified in lignin biosynthesis ${ }^{15,16}$.

Figure 1: Lignin molecule constructed from three 4-hydroxyphenylpropanoids known as monolignols, $p$-coumaryl alcohol, coniferyl alcohol and sinapyl alcohol. Once incorporated into a lignin polymer, they are represented as $p$-hydroxyphenyl $(\mathrm{H})$, guaiacyl $(\mathrm{G})$ and syringyl $(\mathrm{S})$ moieties. The structure depicts types of phenolic inter-unit linkages and possible branch points but does not represent a real lignin as stochiometry has not been considered.

Lignans are also derived from coupling of phenylpropanoid units to produce dimers or oligomers linked via C-C and/or C-O interunit bonds. However, unlike lignin, lignans do not have any known essential structural role in vascular tissues ${ }^{17}$ The 
occurrence and immense diversity of lignan structures have recently been reviewed ${ }^{18}$ and shall not be covered here. The diversification of lignan structures may reflect an underlying arms race as the prime function of lignans is as defense compounds directed towards plant pathogens ${ }^{19}$. Defense reactions of plants include wall repair involving ectopic lignification drawing upon glycosylated monolignols stored in the vacuole and possibly also the lignans released as defense compounds ${ }^{20,21}$. Discriminating experimentally between the involvement in defense of lignin and lignans respectively has been complicated by the discovery of lignin oligomers formed in the cytoplasm and stored in the vacuole ${ }^{22}$, presumably to take part in wall repair during pathogen invasion.

\subsection{Occurrence and physiological function of ferulate cross-links}

Ferulic and $p$-coumaric acid are major hydroxycinnamic acid derivatives that are incorporated into the cell wall and play an important role in cell wall extensibility and biodegradability. Feruloylated polysaccharides are characteristic of two major groups of angiosperms: commelinid monocotyledons (Poales, Commelinales, Zingiberales, Arecales) and the 'core' Caryophyllales ${ }^{23,2}$. In commelinid monocotyledons, ferulic acid is esterified to the glucuronoarabinoxylan (GAX)24; while in Caryophyllales, it is esterified to arabinan and galactan side-chains of rhamnogalacturonan-I (RGI) $)^{25,23,26}$.

Ferulic acid and its oligomers act as important components of the plant cell wall, forming cross-links between polysaccharide chains and lignin, between polysaccharides $^{27}$, and between polysaccharides and proteins ${ }^{28,29,30}$. Oligomerization of the feruloylated polysaccharides tethers these cell wall 
constituents together with implications for the physiological functions of the cell wall with respect to extensibility ${ }^{31,32,33}$, growth cessation ${ }^{34}$, and increasing recalcitrance towards enzymatic degradation and pathogen invasion $35,36,37$. The function of feruloylated structures has been studied in two closely related Chenopodiaceae species, sugarbeet and beetroot. It has been noted that in sugarbeet $20 \%$ of the feruloyl moieties were incorporated into dimers in contrast to only $10 \%$ in beetroot. Sugarbeet can sustain its structure at temperatures of $100^{\circ} \mathrm{C}$ for several hours, whereas beetroot softened within $20-30 \mathrm{~min}$, indicating a role for feruloylation in cell-cell adhesion ${ }^{38}$.

Ferulate-based cross-links are thus critically important. Plant families that do not feature feruloylated polysaccharides may have evolved functionally equivalent cell wall structures in an attempt to overcome this deficiency.

\subsection{Occurrence and physiological function of extensins}

Although cell wall proteins are quantitatively minor components of the cell wall, they are integral to cell wall assembly and architecture. Of the diverse classes of cell wall structural proteins, the role of one subgroup - extensins - is most well understood ${ }^{39,40}$. However, there are other types of cell wall protein cross-links that we will not discuss in detail here, including the cysteine domain (CD) crosslink found in the C-terminal of some glycine rich proteins (AtGRP3 At2g05520, AtGRP3s At2g05380 and At2g05520) ${ }^{41}$. AtGRP3 has been shown to become part of a supramolcular complex with pectin and Wall Associated Kinase 142,43. The farreaching implications of an arabinogalactan protein, APAP, which was 
demonstrated to carry covalently attached arabinoxylan and pectin ${ }^{44}$ also fall outside the scope of this review.

Extensins are particularly relevant here because of their ability to self-assemble. Non-covalent association has been demonstrated between extensins and pectic polysaccharides, in addition to interactions with other cell wall constituents ${ }^{45,46}$. The cell walls of root hairs are vulnerable structures and easily accessible for investigation and, in several extensin mutants, the root hair structure is compromised, see below. Extensin sequence motifs are not only found in structural wall proteins. Leucine Rich Repeat-Extensins (LRX) are extracellular proteins involved in signalling and wall-sensing ${ }^{47,48}$. Genetic lesions in these proteins also result in root hair phenotypes ${ }^{49}$.

The ability of extensins to form covalent cross-links via their tyrosine (Tyr) residues leading to cross-linked structures that superficially are analogous to the ferulic acid cross-links is interesting. At the functional level, the similarity is probably not superficial, as demonstrated in grasses, which lack extensins with cross-link motifs. It is, therefore, tempting to speculate that ferulate cross-links on GAX have made extensin cross-links superfluous in grasses ${ }^{50}$. The cross-linking motifs missing in structural cell wall proteins in grasses are present in their LRXs.

Ringli51 has shown that, in Arabidopsis, Tyr residues in the extracellular domain of, LRX1, have an important function in wall-sensing. However, a carefully prepared truncated series of the apoplastic domain, which included replacing Tyr residues with Phe, led to the conclusion that other mechanisms of anchoring to the wall than 
phenolic cross-links to the wall are at play. As such, it is not necessarily a conundrum that the Tyr domains are retained in grass LRXs even though no extensin partners featuring cross-linking motifs are available.

As for the ferulates, it is assumed that cross-links involving aromatic residues will co-polymerize with lignin during its synthesis41. This is technically difficult to prove and remains an attractive working hypothesis for extensins while good evidence has been provided for ferulates ${ }^{52}$. Extensin-lignin cross-links are well documented ${ }^{53,54,55}$ and demonstrated to be elicitor inducible ${ }^{56}$ but the nature of the cross-links, i.e. if they are phenolic cross-links, remains to be elucidated.

Extensin content is generally low in secondary cell walls (where lignification is quantitatively most prominent), but it has been shown that extensin make a small but measureable contribution to recalcitrance to saccharification for biofuel production ${ }^{57}$. However, the importance of extensins in secondary wall assembly should not be underestimated. Overexpression of an extensin in rice was found to increase secondary wall thickness substantially ${ }^{58}$.

The involvement of extensins in plant defense was realized many years ago ${ }^{59,60}$ and the current status was most recently reviewed by Deepak et $a^{61}$. A recent study examined the effect of heterologous expression of a fungal feruloyl esterase in Arabidopsis. An increased susceptibility to Botrytis cinerea infection was observed as well as a shift to cross-linked extensins ${ }^{62}$. Di-ferulic cross-links are not known in Arabidopsis and the authors proposed that wall-bound ferulic acid in 
dicots are involved in polysaccharide-extensin cross-links. Hence, a reduction in wall associated ferulic acid led to a promotion of extensin self-crosslinking.

\section{Structure and formation of cross-links and phenolic inter-unit linkages} 3.1 Structure and formation of lignin inter-unit linkages

Laccase- and peroxidase-catalyzed formation of monolignol radicals, and subsequent coupling, results in the formation of lignin polymers ${ }^{63}$. This combinatorial coupling of monolignol radicals, which initially leads to the formation of lignin oligomers, may take place intracellularly or in the cell wall ${ }^{21}$. The combinatorial nature of the polymerization process of monolignol radicals contributes to the large structural diversity of lignins. The most abundant linkage between monolignols is aryl $\beta$-aryl ether ( $\left.\beta-0-4^{\prime}\right)$, followed by phenylcoumaran ( $\beta-5^{\prime} / \alpha-$ O-4'), resinol ( $\left.\beta-\beta^{\prime} / \alpha-O-\gamma^{\prime} / \alpha^{\prime}-O-\gamma\right)$, and biphenyl (5-5'), whereas dibenzodioxocin (5-5'/4O- $\left.\beta^{\prime \prime} / 4^{\prime}-O-\alpha^{\prime \prime}\right)$, diaryl ether (4-O-5'), and spirodienone ( $\left.\beta-1^{\prime} / \alpha-O-\alpha^{\prime} / \beta^{\prime}-O-4 "\right)$ linkages also occur but to a much smaller extent ${ }^{64}$ (Figure 2 ). A recent study conducted on poplar natural variants suggests that monomer concentration and transport influence $\mathrm{C}-\mathrm{O}$ and $\mathrm{C}-\mathrm{C}$ bond content during the lignification process ${ }^{65}$. Thus, monomer concentrations also play a dominating role in the resulting shape of lignin $^{6}$. Notably, conifer lignins were found to be more branched compared to lignins in grasses due to the absence of S-units and higher occurrence of dibenzodioxocin inter-unit linkages typically found in high-guaiacyl lignins ${ }^{66}$, whereas more linear lignins can be obtained by transgenic approaches that increase S-unit content ${ }^{67}$.

Figure 2: Common phenolic inter-unit linkages identified in lignin. 1, aryl $\beta$-aryl ether ( $\beta$-O-4'); 2 , phenylcoumaran ( $\left.\beta-5^{\prime} / \alpha-\mathrm{O}-4^{\prime}\right) ; 3$, biphenyl (5-5'); 4, dibenzodioxocin $\left(5-5^{\prime} / 4-\mathrm{O}-\beta^{\prime \prime} / 4^{\prime}-\mathrm{O}-\alpha^{\prime \prime}\right)$; 
5, diaryl ether (4-O-5'); 6, resinol $\left(\beta-\beta^{\prime} / \alpha-\mathrm{O}-\gamma^{\prime} / \alpha^{\prime}-\mathrm{O}-\gamma\right)$; 7, spirodienone $\left(\beta-1^{\prime} / \alpha-\mathrm{O}-\alpha^{\prime} / \beta^{\prime}-\mathrm{O}-\right.$ $4 "$ ); Bonds between monolignols are presented in red color. $\mathrm{R}=\mathrm{H}$ or $\mathrm{OMe} ; \mathrm{L}=$ Lignin backbone.

Because the polymerization process is chemically driven, phenolic radicals other than the traditional monolignols can also be incorporated into lignin if they are present during lignification ${ }^{169}$. For example, non-canonical lignin monomers, such as hydroxycinnamates ${ }^{247}$ ferulate dehydrodimers 68,52 , tricin ${ }^{69,70}$, dihydroconiferyl alcohol $^{71}$, caffeyl alcohol ${ }^{72}$, 5-hydroxyconiferyl alcohol ${ }^{73}$, hydroxycinnamaldehydes ${ }^{74}$, and hydroxystilbenes ${ }^{75}$, were identified as lignin components. Lignins from certain plants are also known to be acylated with

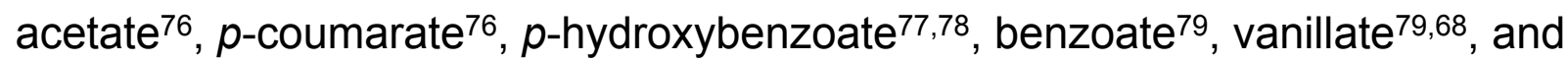
ferulate $^{79}$ (Figure 3).

Figure 3. Examples of lignin acylation. Acyl groups (highlighted in red) can be 9, acetate; 10, pcoumarate; 11, $p$-hydroxybenzoate; 12, benzoate; 13, vanillate; 14, ferulate.

In specific mutants, incorporation of hydroxybenzaldehydes ${ }^{80}$, tyramine ferulate ${ }^{81}$, and naringenin ${ }^{82}$ into lignins have also been observed. Although never observed naturally, rosmarinic acid (a caffeate ester), epicatechin, gallate derivatives, and quercetin glycosides (e.g. hyperoside) have also been demonstrated to incorporate lignin using biomimetic systems ${ }^{83,84}$. These numerous examples of incorporation of non-traditional monomers emphasize the plasticity of lignification biogenesis and challenge an alternative view that proposes an ordered and non-random process of 
lignin formation ${ }^{85}$. Observations on the relative abundances of inter-unit linkages that do not change as expected in lignin of certain mutants and transgenics featuring altered monolignol ratios led some authors to propose a controlled process for monolignol polymerization and suggest that linkage types are not simply controlled by combinatorics, i.e. the concentrations of the different monolignols ${ }^{86}$. Readers can refer to the study of the caffeic acid O-methyl transferase Arabidopsis mutant Atomt 1 for a presentation of this argument ${ }^{87}$.

\subsection{Structure and formation of cross-links involving phenolics on polysaccharides}

\subsubsection{Phenolics on pectic RGI}

$R G I$ is a branched heteropolymer of alternating $\alpha-1,2$-linked rhamnose (Rha) and $\alpha$ 1,4-linked galacturonic acid (GalA) residues. The Rha residues of the RGI backbone can carry neutral side-chains of predominantly 1,4- $\beta$-D-galactose and/or 1,5- $\alpha$-L-arabinose residues. These linkage types were initially discovered in endopolygalacturonase digests of cell walls of suspension cultured sycamore cells ${ }^{88,89}$. RGI biosynthesis is only partly understood. Candidate arabinosyltransferases have been identified ${ }^{90}$, as well as galactosyltransfereases that are involved in building $\beta$ 1,4-galactan side-chains ${ }^{91}$. An assay for backbone synthesizing rhamnosyltransferases has been developed ${ }^{92}$ and used successfully to identify a new family of rhamnosyltransferases ${ }^{93}$.

RGI has a number of specialized roles, e.g. as mucilage ${ }^{94,95}$, but as a general primary wall constituent it displays non-covalent self-assembly properties ${ }^{96}$. The core Caryophyllales side-chains of RGI carry phenolic substituents that are 
potentially involved in cross-linking, Figure 4. In spinach (Spinacia oleracea) and beet (Beta vulgaris) cell walls, ferulic acid mainly esterifies the neutral sugars (arabinan and galactan) of pectic side-chains ${ }^{97,98}$. The exact locations of these ester linkages were determined by treating cell walls from spinach leaves and sugar beet pulp with Driselase, a commercial enzyme mixture from the fungus Irpex lacteus that contains several pectolytic enzymes but lacks hydroxycinnamoyl esterase activities. The side chains of sugar beet RGI can be feruloyl substituted at the $0-2$ in the main backbone of $\alpha-(1,5)$-linked arabinan, the $0-5$ in the terminal arabinose 98 , or the $0-6$ in the backbone of galactan ${ }^{99,25}$. A pectin-extensin crosslink has been demonstrated in sugar beet ${ }^{100}$. The linkage was proposed to be covalent but the type of linkage and hence whether it could be phenolic remains to be determined. A covalent link between RGI and extensin has also been observed in cotton ${ }^{101}$. Cotton is a Rosid and is thus expected to feature very low levels of polysaccharide feruloylation2 but cotton has not been investigated in this regard and the authors do not exclude the possibility of a phenolic cross-link.

Figure 4. Simplified structure of RGI, a pectic polysaccharide with a back-bone of alternating rhamnosyl and galacturonosyl residues. Rhamnosyl residues may carry neutral side-chains and it is a speciality of the Caryophylales plant families that the side-chains are esterified with ferulic acid (shown in red). Monosaccharides are color-coded: Galacturonic acid, orange; rhamnose, dark pink; galactose, blue; arabinose, green.

\subsubsection{Phenolics on xylan}


Xylans comprise a backbone of $\beta-(1 \rightarrow 4)$-linked xylose residues which can be $O$ acetylated and/or substituted at O-2 by $\alpha$-Ara, $\alpha$-GlcA and $\alpha$-MeGlcA side-chains, giving rise to arabinoxylans, glucuronoxylans, and glucuronoarabinoxylans (GAX), respectively ${ }^{102}$. GAX is the major structural component of the Poaceae primary cell wall, with glucuronoxylan alone constituting up to $40 \%$ of the dry mass ${ }^{103,104}$.

Figure 5. Maize pericarp glucuronoarabinoxylan (GAX). A Representative structure with ferulic acid (shown in red) esterified to arabinosyl residues. B and C Two additional identified feruloylated maize GAX side-chains ${ }^{105}$, the one in $\mathrm{C}$ shown with a covalent linkage to lignin. Monosaccharides are colorcoded: Xylose, yellow; arabinose, green; glucuronic acid, purple; L-galactose, blue.

The GAX of the maize pericarp (Figure 5) exemplifies the fine structure of this molecule. This is the most complex xylan known and features the highest degree of feruloylation ${ }^{106}$. Ferulic acid is the most abundant phenolic compound (up to $90 \%$ ) followed by small amounts of $p$-coumaric acid ${ }^{107,108}$. Side-chains comprising glucuronic acid and its 4-O-methyl derivative are linked to the xylan backbone ${ }^{109,110}$. Extensive acylation on xylose and arabinose residues is also observed ${ }^{111,112}$. Xylose residues can be found as 2-linked terminal xylose residues on arabinose or as 2,4-linked xylose, with evidence for an additional terminal galactose at the 4 position ${ }^{113}$ in addition to the 3 -linked L-Gal ${ }^{129}$ shown in Figure 5. The figure provides a generalised structure of maize GAX, which is composed of a $\beta-1,4$-linked xylopyranosyl backbone decorated at the $\mathrm{C}_{2}-\mathrm{O}$ and/or $\mathrm{C}_{3}-\mathrm{O}$ positions with $\alpha$-L- 
arabinofuranose residues. The highly branched structure and few unsubstituted xylosyl residues render maize GAX recalcitrant to hydrolysis ${ }^{114,115}$, which distinguishes maize GAX from wheat and barley $G A X^{116,117}$. Consequently, increased enzyme mediated solubilisation using GH10 and GH11 xylanases has been observed in wheat GAX compared to maize $G A X^{118}$. It has been suggested that no regions in maize xylan exist where several contiguous xylose residues are unsubstituted, making it inaccessible to endo-acting enzymes ${ }^{119}$.

Ferulic acid is typically esterified to the $\mathrm{C}(\mathrm{O}) 5$-hydroxy group of arabinosyl residues in (glucurono)arabinoxylan ${ }^{120,26,121}$. Evidence for the presence of a more alkaline resistant linkage between ferulic acid and GAX, most likely an ether linkage, has been provided by Burr and Fry ${ }^{122}$. Ester formation precedes formation of the more stable linkage observed, and the radical structure, which is an intermediate in oxidative coupling of ferulic acid, was proposed by the authors to form a strong $p$ hydroxybenzyl ether bond via nucleophilic attack by a sugar residue, possibly assisted by an as yet unidentified protein. All possible quinone intermediate radicals generated during the dehydrogenation of a ferulate moiety are shown in Figure 6, top. From these, radical coupling produces ferulate dehydrodimers (e.g. 8-8, 8-O-4, 8-5-linkage, etc.) following cross-linking via nucleophilic addition.

Nucleophilic addition can occur either intra- or inter-molecularily. In the case of intermolecular nucleophilic addition, an oxygen atom is either abstracted from a water molecule to form ether linkages, or from a polysaccharide to form a carbohydrate complex. In order to proceed with this reaction, the sugar nucleophilic 
attack requires the presence of a specific enzyme, or possibly dirigent protein, as water is a stronger nucleophile than alcohols. As such, in a hydrated medium, water competes with the sugar and will be the prominent reactant as indicated in Figure 6.

Figure 6: Three phenolic cross-linking mechanisms, including a tentative mechanism of ether bond formation between ferulic acid and a sugar-OH group ${ }^{115}$ here provided by an arabinosyl residue shown in red. The resonance forms shown result from oxidation of ferulate by peroxidase (this oxidation can also be catalyzed by laccase).

In Norway spruce, NMR analyses of isolated fractions enriched in various polysaccharide-lignin complexes suggested that the carbohydrate and lignin constituents are chemically bonded ${ }^{123}$, which is further supported by the identification of ether-linked lignin nucleation points on both xylan and galactoglucomannan $(\mathrm{GGM})^{124}$. A detailed analysis conducted on Japanese red pine wood using nuclear magnetic resonance spectroscopy evidenced $\alpha$-ether bonds between lignin and the primary hydroxyl group of mannose residues in glucomannan ${ }^{125}$. A one-enzyme mechanism where laccase mediates ether linkage formation has been proposed (Figure 2a, ibid124), a reaction that likewise would suffer from competition with water unless a second, unknown enzyme is introduced $^{126}$.

A key feature of esterified ferulic acid is its ability to form cross-links by oxidative coupling, resulting in the formation of ferulate dimers, trimers, and even tetramers $^{127,128}$ (figure 7). Quantification of feruloylated GAX sidechains is problematic due to a lack of standards, but is possible through mild acidic 
hydrolysis combined with $\mathrm{C}_{18}$-solid phase extraction and LC-DAD/MS ${ }^{129}$. Another reported method to quantify free and ester-linked ferulic acid is based on liquid extraction, precipitation and reverse-phase HPLC ${ }^{130}$. Analysis of the presence of ferulic acid dehydrodimers and dehydrotrimers via alkaline pre-treatment and reverse-phase HPLC has also been reported ${ }^{131,132}$.

Figure 7. Identified ferulate crosslinks in GAX. 15, 8-O-4-DFA (or $\beta$-O-4-DFA); 16, 8-5-DFA (or 8-5-benzofuran-DFA); 17, 8-8 (non-cyclic)-DFA; 18, 8-8-THF-DFA; 19, 8-8 (cyclic)-DFA; 20, 55-DFA; 21, 4-O-5-DFA; 22, 8-O-4/8-5(cyclic)-TriFA; 23, 8-8(cyclic)/5-5-TriFA; 24, 8-5(cyclic)/4O-5/8-5(cyclic)-TetraFA. New bonds formed upon radical coupling are highlighted in red. Abbreviations are DFA (diferulic acid), THF (tetrahydrofuran), TriFA (triferulic acid) and TetraFA (tetraferulic acid).

Formation of ferulate cross-links impedes enzymatic degradation of the cell wall ${ }^{133,134}$. Interestingly, ferulic acid has been shown to cross-link other polysaccharides, lignin, and possibly even proteins ${ }^{135}$. In cell walls of maize, 5-5coupled diferulate dimerization cross-links xylans, a process that may result in coupling to lignin52. Administration of radiolabeled arabinose to maize cellsuspension cultures showed extensive cross-linking to soluble polysaccharides, including xylans and xyloglucans ${ }^{136}$. Maize xylan-associated glucuronic acid substitutions mediate cross-linking between neighboring xylan chains and cellulose surfaces, and are stabilized by $\mathrm{Ca}^{2+}$ as shown by molecular dynamics ${ }^{137}$. Recent solid-state NMR and molecular genetics studies showed that the GAX fine structure, in particular the positioning of GICA/GICA-Me side-chains and acylation influence its interaction with cellulose. The two-fold helical screw configuration 
adopted by GAX in the secondary cell wall enables interaction with hydrophilic surfaces and serves to assemble the cellulose fibrils in higher order structures ${ }^{138}$. This interaction has been observed in freshly hydrated cell walls indicating that water - and hydrogen bonding - plays a crucial role in this context despite the xylan conformation in water being a threefold helical screw ${ }^{139}$; the same conformation observed in dried cell walls. In primary cell walls, interactions between pectin and cellulose have also been reported ${ }^{140,141}$. As such, phenolic cross-linking of matrix polysaccharides in the wall appear to create networks that comprise cellulose microfibrils.

Mutants that affect GAX fine structure in ways that, for example, abolish points of feruloylation, are relevant to cross-linking. Xylan biosynthesis is rather well understood ${ }^{142}$ and the sites of feruloylation have been mapped in maize ${ }^{143}$. However, the mechanism of xylan feruloylation remains a conundrum as shall be discussed below.

\section{Substrate and localization of feruloylation}

The substrate for feruloylation of arabinoxylan is not clearly defined but may require initial activation via feruloyl-CoA formation. In crude fractions isolated from rice tissue, ferulic acid is indeed transferred to arabinoxylan from feruloyl-CoA ${ }^{144}$. However, this cannot be taken as a proof of feruloyl-CoA being a substrate for the feruloylation, as the experiment did not exclude the possibility that short feruloylated polysaccharides are recognized by transferases responsible for protein feruloylation ${ }^{145}$. Feruloyl glucose has been proposed as an alternative substrate because increased levels of hydroxycinnamate esters in non-lignified cell wall 
material was observed in a transgenic aspen line with antisense down-regulated 4coumaroyl:CoA ligase (4CL) $)^{146,147}$. Two possible pathways for arabinoxylan feruloylation have been suggested ${ }^{148}$. The first involves the initial synthesis of arabinoxylan followed by feruloylation while the other proposes that the feruloylation pathway proceeds through an initial reaction of feruloyl-CoA with UDPAra to form UDP-Ara-Fer, which later acts as a donor to the growing arabinonoxylan chain148. Either of these possibilities point to feruloylation occurring in the secretory pathway, and this notion is backed up by experimental evidence. Pulse-chase experiments with labeled arabinose in suspension cultures of Festuca arundinacea documented that feruloylation of polysaccharides preceded export to the wall ${ }^{149,150}$. Evidence for apoplastic feruloylation has also been presented ${ }^{151}$ : Kinetic studies of feruloylation based on ${ }^{14} \mathrm{C}$-cinnamic acid and use of the secretory pathway inhibitor Brefeldin A (BFA) demonstrated that the BFAtreatments only had a marginal effect on the incorporation of radiolabeled ferulic acid into the wall. By contrast, the incorporation of radiolabelled arabinose was significantly impaired. The conclusion from this was that polysaccharides already deposited in the wall could be subject to feruloylation, a mechanism that could be instrumental for pathogen defense151. The substrate for feruloylation, whether intra- or extra-cellular, and the exact biochemistry of these processes are yet to be elucidated. However, identification of the acyl transferases involved in feruloylation, and direct substrate studies, would allow the mechanism to be deciphered.

\subsubsection{Genes involved}


Many studies have focused on elucidating the structures of the ferulate conjugating components of the cell wall, and how these cross-links are formed. Interest in biofuel has led to progress within the last few years in elucidating the cell biology of feruloylation. So far, a few of the arabinonoxylan feruloyl transferase (AFT) genes are known. Based on the assumption that genes encoding AFTs involved in arabinoxylan biosynthesis in grasses would be more highly expressed than in their dicot orthologs, transcriptome profiling suggests that the AFTs could belong to the BAHD family of transferases ${ }^{152}$. BAHD enzymes are also implicated in lignification, section 4.1.2, and they are named after the first four members that were biochemically characterized in this family (i.e. benzylalcohol acetyltransferase, BEAT; anthocyanin hydroxycinnamoyl transferase, AHCT; anthranilate hydroxycinnamoyl/benzoyl transferase, HCBT; deacetylvindoline acetyltransferase, DAT $\left.{ }^{153}\right)$. They are also designated as members of the PF02458 family of domaincontaining transferases, which are known to include hydroxycinnamoyl transferases $^{154}$ and acetyl transferases ${ }^{155}$.

Experimental evidence for transferases from the PF02458 family being involved in feruloylation of arabionoxylan was obtained from rice ${ }^{156}$, Brachypodium distachyon ${ }^{157}$, and Setaria viridis ${ }^{158}$. It was reported that, in rice, the ferulic acid and $p$-coumaric acid content correlated with the transcription level of specific BAHD encoding genes. Twelve transferases clustered together in a neighbor-joining tree and were assigned to 5 classes (I-V). Direct evidence for their involvement in arabinoxylan acylation was obtained using RNAi transgenic plants and comparing 
ferulic and $p$-coumaric acid levels to the control plants. Down regulation of genes encoding the group III and IV transferases specifically reduced the content of ferulic acid, whereas down-regulation of genes encoding group I and II transferases had a modest effect on $p$-coumaric acid content in the stem. Genes encoding group $V$ transferases were only expressed at low levels in the roots and vegetative tissue and were not included in further experiments. The authors proposed that the processes affecting the incorporation of ferulic and $p$-coumaric acid may not be connected and instead are controlled separately by different transferase members of the BAHD family ${ }^{156}$. Table 1 lists grass BAHDs implied to be involved in arabinoxylan acylation. 
Table 1: BAHDs genetically involved in arabinoxylan acylation

\begin{tabular}{|c|c|c|c|c|}
\hline Gene name & $\begin{array}{l}\text { Accession number / } \\
\text { BAHD clade }\end{array}$ & $\begin{array}{l}\text { Approach to modify gene } \\
\text { expression }\end{array}$ & Observed phenotype & Reference \\
\hline OsAT10 & Os06g39390 / IV & $\begin{array}{l}\text { Overexpression by activation } \\
\text { tagging in rice }\end{array}$ & $\begin{array}{l}60 \% \text { reduction and } \\
300 \% \text { increase in cell } \\
\text { wall esterified ferulates } \\
\text { and } p \text {-coumarate, } \\
\text { respectively, in young } \\
\text { leaves }\end{array}$ & 159 \\
\hline$B d A T 1$ & Bradi2g43520 / I & $\begin{array}{l}\text { 1) RNA silencing and 2) } \\
\text { p35S overexpression in } \\
\text { Brachypodium distachyon }\end{array}$ & $\begin{array}{l}\text { 1) } 35 \% \text { reduction in cell } \\
\text { wall esterified ferulates } \\
\text { and diferulates in both } \\
\text { leaves and stems } \\
\text { 2) } 58 \% \text { and } 47 \% \\
\text { increase in cell wall } \\
\text { esterified ferulates and } \\
\text { diferulates in leaves and } \\
\text { stems, respectively }\end{array}$ & 157 \\
\hline $\begin{array}{l}\text { Os05g08640 } \\
\text { Os06g39470 } \\
\text { Os01g09010 } \\
\text { OsAT10 }\end{array}$ & $\begin{array}{l}\text { Os05g08640 / III } \\
\text { Os06g39470 / III } \\
\text { Os01g09010 / IV } \\
\text { Os06g39390 / IV }\end{array}$ & $\begin{array}{l}\text { Simultaneous RNAi } \\
\text { silencing in rice }\end{array}$ & $\begin{array}{l}19 \% \text { reduction in cell } \\
\text { wall esterified ferulates } \\
\text { in leaves }\end{array}$ & 156 \\
\hline SvBAHD01 & Sevir.5G130000 / IV & $\begin{array}{l}\text { RNAi silencing in Setaria } \\
\text { viridis }\end{array}$ & $\begin{array}{l}\sim 65 \% \text { and } \sim 35 \% \\
\text { reduction in } \\
\text { arabinoxylan } \\
\text { feruloylation in stems } \\
\text { and leaves, respectively. } \\
30-150 \% \text { increase in } \\
\text { arabinoxylan } p \text { - } \\
\text { coumaroylation }\end{array}$ & 158 \\
\hline$B d B A H D 01$ & Bradi2g05480 / IV & $\begin{array}{l}\text { RNAi silencing in } \\
\text { Brachypodium distachyon }\end{array}$ & $\begin{array}{l}10-20 \% \text { reduction in } \\
\text { arabinoxylan } \\
\text { feruloylation in stems }\end{array}$ & 158 \\
\hline
\end{tabular}

More recently, using a transgenic approach, a BAHD from clade I in Brachypodium (BdAT1) was shown to participate in arabinoxylan feruloylation157. Overexpression and downregulation of $B d A T 1$ resulted in an increase and a decrease of cell-wall ferulate levels, respectively. Similarly, two BAHDs from clade IV in Setaria viridis (SvBAHD01) and Brachypodium (BdBAHD01) have been implicated in arabinoxylan feruloylation since their silencing also resulted in reduced ferulate levels158. Interestingly, in the case of Setaria viridis, the decrease of ferulate was 
accompanied by an increase of $p$-coumarate esters on arabinose and an improvement of biomass saccharification.

The group of BAHD acyltransferases contains more proteins than initially thought. At present, twenty members potentially involved in xylan acetylation have been identified in various bioinformatics studies159, whereas Mitchell's clade152 comprised only 12. An acyltransferase OsAT10 mutant in rice was characterised and it was found that increased expression of OsAT10 (encoding a BAHD from group IV) resulted in an increased level of $p$-coumaric acid conjugation and a reduced level of conjugated ferulic acid159. This indicates that the enzyme encoded by OsAT10 is responsible for the incorporation of $p$-coumaric acid into a precursor of arabinoxylan. Changes observed in hydroxycinnamic acids levels are related to the TFA-soluble matrix polysaccharides but not to lignin. $p$-Coumaric acid predominantly acylates lignin and feruloylated arabinoxylan. However, no evidence that OsAT10 has p-coumaric acid monolignol acyltransferase activity was found. Recently, overexpression of OSAT10 in switchgrass also modified the ratio of cellwall-bound $p$-coumaric acid to ferulic acid, which resulted in an improvement of biomass saccharification efficiency ${ }^{160}$. The stage in arabinoxylan formation at which the coupling of ferulic acid to arabinose occurs has been investigated in rice ${ }^{161} . \mathrm{XAX} 1$, which belongs to glycosyltransferase family GT61, is a xylosyltransferase required for xylosyl substitution of the arabinosyl residue that is optionally feruloylated (Figure 5). It was found that insertional mutants of the xax 1 gene presented a decreased feruloyl and 
coumaroyl ester content. This implies that a side-chain exclusively built by Ara residues is a poorer substrate for feruloylation than an Ara-Xyl side-chain. If BAHD enzymes acylate an intermediate substrate to be transported into the secretory pathway, then UDP-arabinofuranose (UDP-Araf) would be a suitable candidate. However, if UDP-Araf were a substrate for feruloylation of xylan, the decrease in ferulate esters would not be observed in the xax1 mutant. This led to the conclusion that another, yet unidentified, compound is involved as a feruloylation intermediate. The feruloylated protein mentioned above might be considered as the "unknown intermediate". Presently, feruloylated proteins have not been identified and it is not obvious how transport into the secretory pathway would be mediated. One candidate set of proteins is the GT75s/Reversible Glycosylated Polypeptides, which act as UDP-Arap/Araf mutases ${ }^{162}$ and are located on the cytoplasmic face of Golgi ${ }^{163}$. In this position they are, therefore, exposed to the cytoplasmic BAHDs. UDP-Araf-Fer would again be the compound required to pass into the Golgi lumen, leaving the xax1 mutant phenotype unaccounted for.

Characterized BAHDs use aromatic and lipophilic acceptors ${ }^{164,165,166}$ and this also applies to Mitchell's clade of BAHDs in grasses (discussed below). As such, the possibility that the intermediate is a small lipophilic hydroxyl-cinnamate ester that can pass passively or be easily transported into the secretory pathway should be entertained and would suggest that the target enzyme for the final acylation of GAX is a trans-esterase. However, it has been suggested that the intermediate is an 
arabinosyl-ferulate ester, likewise calling for a trans-esterase being responsible for the final acylation21.

3.2.4 Other hydroxycinnamates in the cell wall p-Coumaric acid and sinapic acid are phenylpropanoids structurally related to ferulic acid. They are also detected in the cell wall but are much less abundant. Although p-coumaric acid can undergo cyclodimerization, and theoretically take part in the cross-linking of the polysaccharide chains, its oxidative coupling products were not detected in planta ${ }^{167}$. Sinapic acid and its dehydrodimerization products (8-0-4 and 8-8 linkage type) have been isolated from cereal grain dietary fibers (wheat, spelt, rye, and wild rice), and supposedly play the same role as ferulates in the plant cell wall. Sinapate-ferulate structures were also observed. In combination with ferulic acid, sinapic acid can - in addition to 8-O-4 and 8-8 bonds - form 8-5 and 5-5 bonds. Heterogeneous phenolic coupling provides an opportunity for formation of more complex structures ${ }^{168,169}$.

\subsection{Structure and formation of cross-links in extensins}

Extensins are characterized by their distict glycosylation pattern, featuring short arabinoside chains appended to hydroxy-proline (Hyp) residues, see Figure 8A.

Figure 8. A. Simplified contiguous Pro glycosylation motif featuring the four arabinosides, Hyp-Ara ${ }_{1}$ to Hyp-Ara ${ }_{4}$, found in most plants and single Gal side-chain on Ser.

Glycosyltransferases responsible for building the side-chains are indicated in blue. The ordering of the side-chains shown is arbitrary as the arrangement of the arabinosides is 
unknown. B. Staggered partial alignment of Arabidopsis Ext3 favours cross-links featuring pulcherosine ${ }^{45}$. Hydrophobic residues are shaded; the darkest are those involved directly in the cross-links. $\mathrm{O}$ is the one-letter code for hydroxyproline. C. Isodityrosine, cross-linking of two extensins with pulcherosine ${ }^{182}$ as indicated in panel $\mathrm{B}$, and di-isodityrosine $\mathrm{e}^{181}$. Monosaccharides are color-coded: arabinose, green; galactose, blue.

The positioning of the Tyr residues, as well as the glycan structure, is integral to cross-linking in extensins. The importance of extensin O-glycosylation, and in particular the fourth Araf residue, for cross-linking has been substantiated via in vitro studies ${ }^{170}$, which demonstrated that the initial rate of cross-linking was primarily determined by the number of cross-linking motives in the protein backbone and by Hyp-Ara ${ }_{4}$ content (arabinoside chain-length distribution is considered specites specific ${ }^{171}$ with cotton fibres being the only cell type for which developmental control of chain-lengths has been documented ${ }^{172}$ ). Recent in vivo studies corroborate this observation of the importance of arabinosides: Extensins are important to root-microbe interactions and are present also in secreted mucilage. Lesions in RRA or xeg113 affect cross-linking and lead to modified mucilage compositon ${ }^{173}$. Grasses are thought not to cross-link their extensins due to the absence of the $Y X Y$ motif. As such, the protein backbone sequences vary significantly across the plant Kingdom, with notable differences between grasses and other flowering plants155, whereas extensin O-glycosylation is as old as the green plant lineage ${ }^{174}$, hence the use of gene and protein names that relate to Arabidopsis in the tables below. 
A prerequisite for glycosylation is the hydroxylation of Pro residues to yield Hyp. The motifs required for this have recently been reviewed ${ }^{175}$. In Arabidopsis, knockout and RNAi-studies of the responsible proline-4-hydroxylases (P4Hs) demonstrated that cell walls of root hairs are compromised if $\mathrm{P} 4 \mathrm{H} 2$, $\mathrm{P} 4 \mathrm{H} 5$ or $\mathrm{P} 4 \mathrm{H} 13$ are downregulated ${ }^{176,177,178}$. Interestingly, Hyp formation, while necessary, is not sufficient for correct root hair formation. Arabinosylation is also required as knocking-out RRA and XEG113 arabinosyltransferases also lead to compromised root hairs 177 .

In Chlamydomonas, arabinosylation of cell wall proteins leads to an extended conformation of the peptide backbone ${ }^{179}$. This may be of relevance to cross-linking via the $Y X Y$ crosslinking motif. Meanwhile, intrachain cross-linking of this motif to yield isodityrosine has been demonstrated ${ }^{180}$. The isodityrosine structure cannot be formed between neighboring Tyr residues but is sterically feasible based on the YXY sequence motif. The formation of interchain cross-links, both the tetrameric Tyr cross-link, di-isodityrosine ${ }^{181}$, the pulcherosine cross-link ${ }^{182}$, and arabinosylation of sequences interspacing the $Y X Y$ motives were suggested to provide a conformational contraint that favors interpolypeptide cross-links since the glycosylation restricts polypeptide folding. In Arabidopsis, direct visualization of selfassembled extensin-3 (AtEXT3) has been accomplished ${ }^{183}$. Knockout mutants in this gene are embryo-lethal as this extensin is directly involved in the assembly of new cross-walls as cells divide. The AtEXT3 sequence features 11 repeats with YXY cross-linking motifs and sites for arabinosylation, which indicates that the 
staggered alignment of cross-linking motifs (Figure 8b, and 8c) provides the scaffold for the establishment of extensin cross-links. It is tempting to speculate that the isodityrosine moiety would form in the Golgi and the di-isodityrosine cross-link would form in the apoplast. However, so far this has not been investigated. In Arabidopsis, a study of phenotypic revertants of the AtEXT3 knockout mutant enabled classification of 20 extensins according to isodityrosine content ${ }^{184}$. Extensins, $\mathrm{P} 4 \mathrm{Hs}$, and extensin decoration glycosyltransferases are listed in Table 2. 
Table 2: Extensin genes and genes involved in post-translational modifications that influence tyrosine cross-linking of extensins

\begin{tabular}{|l|l|l|l|l|}
\hline $\begin{array}{l}\text { Gene } \\
\text { name }\end{array}$ & $\begin{array}{l}\text { Arabidopsis } \\
\text { AGI locus }\end{array}$ & Approach to modify gene expression & Observed phenotype / Function / Expression/ Other & Reference \\
\hline
\end{tabular}

\begin{tabular}{|c|c|c|c|c|}
\hline AtEXT3 & At1921310 & T-DNA line and in vitro assay & $\begin{array}{l}\text { rsh (ROOT-SHOOT-HYPOCOTYL DEFECTIVE, RSH) } \\
\text { Essential for cell plate formation, hence the knock out mutant } \\
\text { AtEXT3 is lethal }\end{array}$ & 185,183 \\
\hline $\begin{array}{l}\text { AtEXT6/ } \\
\text { (S7) }\end{array}$ & AT2G24980 & T-DNA line (SALK_010820) & Impaired roothair phenotype & 177 \\
\hline $\begin{array}{l}\text { AtEXT7 } \\
\text { (S11) }\end{array}$ & AT4G08400 & T-DNA line (Sail_882_D02) & Impaired roothair phenotype & 177 \\
\hline EXT8 & At2g43150 & & & \\
\hline EXT9 & At3g28550 & & & \\
\hline $\begin{array}{l}\text { EXT10/ } \\
\text { S14) }\end{array}$ & AT5G06640 & T-DNA line (SALK_099527) & Impaired roothair phenotype & 177 \\
\hline $\begin{array}{l}\text { EXT11 } \\
\text { (S16) }\end{array}$ & AT5G49080 & T-DNA line (SALK_035869) & Impaired roothair phenotype & 177 \\
\hline $\begin{array}{c}\text { EXT12 } \\
(\mathrm{S} 18)\end{array}$ & AT4G13390 & T-DNA line (Sail_1249_F11) & Impaired roothair phenotype & 177 \\
\hline EXT13 & At5g06630 & & & \\
\hline EXT14 & At5g06640 & & & \\
\hline EXT15 & At5g35190 & & & \\
\hline EXT1/4 & At1976930 & & & \\
\hline EXT19 (S) & At5g19810 & & & \\
\hline (22S) & At4g08370 & & & \\
\hline
\end{tabular}




\begin{tabular}{|c|c|c|c|c|}
\hline (21S) & At1g26250 & & & \\
\hline (20S) & At1g26240 & & & \\
\hline $\mathrm{P} 4 \mathrm{H} 2$ & At3g06300 & $\begin{array}{l}\text { T-DNA line P4H2.1 (SALK_042128), } \\
\text { P4H2.2 (SALK_118623) }\end{array}$ & $\begin{array}{l}\text { EXT type prolyl-C4-hydroxylase } \\
\text { Impaired roothair phenotype and reduced HYP } \\
\text { coexpressed with six different EXTsBlee et al (2001) }\end{array}$ & $\begin{array}{l}176 \\
177 \\
178\end{array}$ \\
\hline P4H5 & At2g17720 & T-DNA line (SALK_152869) & Impaired roothair phenotype and reduced HYP & 177 \\
\hline AtP4H13 & AT2G23096 & TDNA line (SAIL 425_H02) & Impaired roothair phenotype and reduced HYP & $\begin{array}{l}177 \\
178 \\
\end{array}$ \\
\hline AtSGT1 & At3g01720 & $\begin{array}{l}\text { sgt1-1 (SALK_059879) } \\
\text { sgt1-2(SALK_054682) }\end{array}$ & $\begin{array}{l}\text { serine O- } \alpha \text {-galactosyltransferase, GT96, } \\
\text { ER and Golgi localized. Longer roots, larger rosettes }\end{array}$ & 186 \\
\hline $\begin{array}{l}\text { AtHPAT1,2 } \\
, 3\end{array}$ & $\begin{array}{l}\text { At5g25265 } \\
\text { At2g25260 } \\
\text { At5g13500 }\end{array}$ & $\begin{array}{l}\text { hpat1 (GABI_298B03), hpat2 } \\
\text { (SAIL_178_H04), hpat3 } \\
\text { (SALK_047668) }\end{array}$ & $\begin{array}{l}\text { hydroxyproline } 0-\beta \text {-arabinosyltransferase } \\
\text { Golgi localized. GT95 } \\
\text { Impaired pollen tube growth, defects in cell wall thickening, } \\
\text { enhanced hypocotyl elongation, shorter root hairs. }\end{array}$ & $\begin{array}{l}187 \\
188\end{array}$ \\
\hline $\begin{array}{l}\text { AtRRA } 1 \cdot 2, \\
3\end{array}$ & $\begin{array}{l}\text { At1g75120 } \\
\text { At1g75110 } \\
\text { At1g19360 }\end{array}$ & 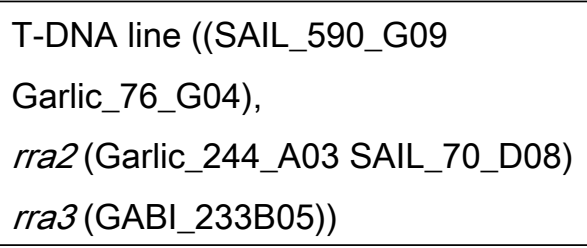 & $\begin{array}{l}\beta-1,2 \text {-arabinosyltransferase, Golgi localized. GT77 } \\
\text { Reduced root hair growth and reduced levels of arabinose in } \\
\text { the mutant. } \\
\text { RRA2 has meristem specific expression }\end{array}$ & $\begin{array}{l}189 \\
177 \\
39\end{array}$ \\
\hline AtXEG113 & At2g35610 & $\begin{array}{l}\text { T-DNA line (xeg113-1 } \\
\text { (SALK_066991), } \\
\text { xeg113-3(SALK_058092)) }\end{array}$ & $\begin{array}{l}\beta-1,2 \text {-arabinosyltransferase, } \\
\text { Golgi localized, GT77. Reduced root hair growth and reduced } \\
\text { levels of arabinose in the mutant }\end{array}$ & $\begin{array}{l}190 \\
177\end{array}$ \\
\hline AtExAD & At3g57630 & $\begin{array}{l}\text { T-DNA lines (exad1-1 } \\
\text { (SAIL_843_G12), exad-2 } \\
\text { (SALK_206288C) exad1-3 } \\
\text { (SALK_204414C)) }\end{array}$ & $\begin{array}{l}\alpha-1,3 \text {-arabinosyltransferase } \\
\text { GT47, Golgi localized. Reduced root hair growth and reduced } \\
\text { levels of arabinose in the mutant }\end{array}$ & 191 \\
\hline
\end{tabular}




\subsection{Lignin nucleation and co-polymerization}

Ferulic acid is a key compound in the cell wall, tethering lignin and polysaccharides in grasses via ether-linkages between lignin monomers and ferulic acid (Figure 5C). As previously described, ferulic acid may also act as a nucleation site for lignification 167,192. Recent studies on fractionation of wheat straw lignin revealed a distinct fraction with lower lignin content and higher ratios of arabinoxylan chains esterified by ferulic acid forming dimers, structures which were considered to represent lignin nucleation sites ${ }^{193}$. The isolation of ether-linked ferulic acid-coniferyl alcohol from saponified wheat and oat straw extracts provides evidence for the lignin-ferulate cross-link. The first identified structures of ferulate-monolignol coupling products were two isomers of $\beta-0-4$ dimers $^{194}$. Subsequently $8-5$ and $8-\beta$ dimers were also identified ${ }^{195}, 121$, see Figure 2 . The proposed order of crosslinking reactions in the cell walls is as follows: first the ferulate is esterified to arabinoxylan and then the feruloyl arabinoxylan is linked to lignin via ether bonds. Eventually the amount of ether-bound ferulate equals that of the esterified form ${ }^{196}$. We will return to this subject in section 4.1.2 (BAHD transferases) and in section 6.4 (Engineering lignin cross-links).

p-Coumaric acid and other hydroxycinnamic acids are structurally related to ferulic acid with variations in their aromatic ring hydroxylation pattern and methoxylation, which results in different in vivo properties. $p$-Coumaric acid, which was isolated following mild saponification of the cell wall, mainly acylates lignin (and to a minor extent arabionoxylans) in immature tissues ${ }^{197,198}$. Some studies have shown that syringyl units are enzymatically pre-acylated with $p$-coumaric acid before their 
incorporation into lignin. The observation that a higher $p$-coumaric acid content is detected in stems than in leaves, and that lignification is higher in stems than in leaves, corroborates the notion that $p$-coumaric acid is involved in the lignification process156. $p$-Coumarate essentially acts as a 'radical catalyst' and has been proposed to be involved in the radical transfer mechanism required for lignin formation ${ }^{199,192 . ~ H o w e v e r, ~ e v e n ~ t h o u g h ~} p$-coumaric acid is readily oxidized to produce radicals, it does not undergo oxidative coupling. In addition, no dimerization product has been detected in plants. Oxidized $p$-coumaric acid transfers the radical to sinapyl alcohol producing more stable radicals and facilitating the polymerization of lignin167.

Polysaccharides esterified with $p$-coumaric acid have been isolated but are present in minor amounts compared to ferulic acid-acylated polysaccharides197,198. Finally, tricin was recently established as a true lignin monomer in some commelinid monocot species69,70 (Figure 9). After oxidation, both tricin and monolignols (or monolignol acetate or p-coumarate conjugates) may associate via radical coupling reactions to form tricin-(4'-O- $\beta$-linked dimers69,200. As tricin is incorporated into a polymer in the form of $4^{\prime}-\mathrm{O}-\beta$-coupled products and their higher oligomers, each tricin unit should localize at the initiating end of its lignin chain. Consequently, tricin acts as a nucleation site for lignin chain extension in monocots, a role that is also played by ferulate on arabinoxylans ${ }^{201}$. 
Figure 9. Tricin derivatives have been identified in lignin in grasses and other commelinid monocots. Three families of tricin derivaties, $\mathrm{a}, \mathrm{b}$ and $\mathrm{c}$, are whown with $\mathrm{T}=\operatorname{tricin} ; \mathrm{G}=$ guaiacyl unit; $\mathrm{S}=$ syringyl unit; $\mathrm{HP}=p$-hydroxyphenyl unit.

\section{Cross-linking enzymes}

4.1 Enzymes involved in lignin polymerization

Both peroxidases and laccases are responsible for catalyzing oxidative coupling reactions. Secreted peroxidases (class III) have been extensively gene duplicated and neofunctionalized. Peroxidases play roles in both scission of cell wall polymers and in the formation of cross-links in the wall202,203. In addition, peroxidases appear to be the prime enzyme catalysts for ferulic acid cross-linking ${ }^{204}$ and the activity appears to be specific122. Laccases, at least the microbial enzymes, catalyze both cleavage and polymerization of lignin in vitro 205 .

\subsubsection{Laccases and peroxidases}

Laccase and class III peroxidase enzymes belong to large multigene families. The overlapping expression patterns of the different members, as well as their apparent functional redundancy, make it challenging to assess the role of individual oxidoreductases in lignification. Arabidopsis contains 17 laccase genes ${ }^{206}$ and 73 peroxidase genes 207 .

The number of genes encoding putative class III peroxidases appears to be even higher in grasses, with respectively 143,138 , and more than 300 candidates in Brachypodium $^{208}$, rice ${ }^{209}$, and the bioenergy crop switchgrass ${ }^{210}$. Recent reverse genetic studies have implicated several members in lignification (Table 3). 
Table 3: Peroxidases and laccases genetically implicated in lignification.

\begin{tabular}{|c|c|c|c|c|}
\hline $\begin{array}{l}\text { Gene } \\
\text { name }^{\mathrm{a}}\end{array}$ & $\begin{array}{l}\text { Accession number / } \\
\text { alternative name } \\
\text { (group) }^{\mathrm{b}}\end{array}$ & $\begin{array}{l}\text { Approach to modify } \\
\text { gene expression }\end{array}$ & Observed phenotype & Reference \\
\hline AtPrx 2 & $\begin{array}{l}\text { At1G05250 / AtP11 } \\
\text { (L) }\end{array}$ & T-DNA insertion & $\begin{array}{l}11 \% \text { reduction of lignin } \\
\text { content. } 25 \% \text { reduction } \\
\text { in the atprx } 2 / \text { atprx } 25 \\
\text { double mutant }\end{array}$ & 211 \\
\hline $\operatorname{AtPrx} 4$ & $\begin{array}{l}\text { Atlg14540/AtP46 } \\
\text { (B) }\end{array}$ & T-DNA insertion & $\begin{array}{l}37 \% \text { reduction of lignin } \\
\text { content under long-day } \\
\text { conditions. Decrease of } \\
\text { S-units }\end{array}$ & 230 \\
\hline AtPrx 17 & $\begin{array}{l}\text { At2g22420/AtP25 } \\
\text { (D) }\end{array}$ & $\begin{array}{l}\text { T-DNA insertion } \\
\text { 35S Overexpression }\end{array}$ & $\begin{array}{l}\text { Reduction of lignin } \\
\text { content. } \\
\text { Increased lignin content }\end{array}$ & 212 \\
\hline $\operatorname{AtPrx} 25$ & At2G41480 & T-DNA insertion & $\begin{array}{l}12 \% \text { reduction of lignin } \\
\text { content. } 25 \% \text { reduction } \\
\text { in the atprx } 2 / \text { atprx } 25 \\
\text { double mutant }\end{array}$ & 211 \\
\hline AtPrx52 & $\begin{array}{l}\text { At5g05340 / AtP49 } \\
\text { (B) }\end{array}$ & T-DNA insertion & $\begin{array}{l}12 \%-22 \% \text { reduction of } \\
\text { lignin content. Decrease } \\
\text { of S-units }\end{array}$ & 213 \\
\hline AtPrx64 & $\begin{array}{l}\text { At5g42180/AtP17 } \\
(\mathrm{H})\end{array}$ & $\begin{array}{l}\text { Endodermis-specific } \\
\text { artificial microRNA } \\
\text { knockdown }\end{array}$ & $\begin{array}{l}\text { Delay in the formation } \\
\text { of functional Casparian } \\
\text { strips }\end{array}$ & 214 \\
\hline $\operatorname{AtPrx} 71$ & At5g64120 / AtP15 (I) & T-DNA insertion & Increased $\mathrm{S} / \mathrm{G}$ & 215 \\
\hline AtPrx 72 & At5g66390 & T-DNA insertion & $\begin{array}{l}60 \% \text { reduction of lignin } \\
\text { content, reduced } \mathrm{S} / \mathrm{G}\end{array}$ & 231 \\
\hline NtPrx60 & AF149251 & $\begin{array}{l}\text { Antisense } \\
\text { downregulation in } \\
\text { tobacco }\end{array}$ & $\begin{array}{l}40-50 \% \text { reduction of } \\
\text { lignin content }\end{array}$ & 216 \\
\hline PtrPO21 & & $\begin{array}{l}\text { downregulation in } \\
\text { Populus trichocarpa }\end{array}$ & $\begin{array}{l}20 \% \text { reduction of lignin } \\
\text { content }\end{array}$ & 217 \\
\hline $\operatorname{PrxA3a}$ & $D 38050$ & $\begin{array}{l}\text { Antisense } \\
\text { downregulation in } \\
\text { hybrid aspen }\end{array}$ & $\begin{array}{l}\text { Up to } 20 \% \text { reduction of } \\
\text { lignin content }\end{array}$ & 218 \\
\hline tpxl & $L 13654$ & $\begin{array}{l}35 \mathrm{~S} \text { Overexpression in } \\
\text { tomato }\end{array}$ & $\begin{array}{l}40 \%-225 \% \text { increase of } \\
\text { lignin content }\end{array}$ & 219 \\
\hline$B d L A C 5$ & Bradilg66720 & TILLING mutant & $\begin{array}{l}10 \% \text { reduction of lignin } \\
\text { content. }\end{array}$ & 220 \\
\hline PtLAC2 & Potri.008G064000 & RNA silencing & $\begin{array}{l}\text { No change in lignin } \\
\text { content. Increased S/G }\end{array}$ & 221 \\
\hline AtLAC4 & At2g38080 & T-DNA insertion & $\begin{array}{l}13.5 \% \text { reduction of } \\
\text { lignin content. } 20-40 \% \\
\text { reduction in the } \\
\text { lac4/lac } 17 \text { double } \\
\text { mutant }\end{array}$ & 222 \\
\hline AtLAC11 & At5g03260 & T-DNA insertion & $\begin{array}{l}\text { Growth arrest and no } \\
\text { lignin staining in the } \\
\text { roots in the } \\
\text { atlac4/atlac17/atlac11 } \\
\text { triple mutant. }\end{array}$ & 223 \\
\hline
\end{tabular}




\begin{tabular}{|c|c|c|c|c|}
\hline AtLAC15 & At5g48100 & T-DNA insertion & $\begin{array}{l}30 \% \text { reduction of lignin } \\
\text { content in seeds }\end{array}$ & 224 \\
\hline AtLAC17 & At5g60020 & T-DNA insertion & $\begin{array}{l}14 \% \text { reduction of lignin } \\
\text { content. Reduced G- } \\
\text { units in interfascicular } \\
\text { fibers. } 20-40 \% \\
\text { reduction in the } \\
\text { lac4/lac17 double } \\
\text { mutant }\end{array}$ & 222 \\
\hline GhLacl & $K X 822020.1$ & $\begin{array}{l}\text { 35S Overexpression } \\
\text { and RNA silencing in } \\
\text { cotton }\end{array}$ & $\begin{array}{l}\text { Increased and decreased } \\
\text { lignin content, } \\
\text { respectively }\end{array}$ & 225 \\
\hline $\begin{array}{l}\text { PtrLAC1 } \\
\text { PtrLAC2 } \\
\text { PtrLAC8 } \\
\text { PtrLAC14 } \\
\text { PtrLAC15 } \\
\text { PtrLAC18 } \\
\text { PtrLAC23 } \\
\text { PtrLAC24 } \\
\text { PtrLAC26 } \\
\text { PtrLAC30 } \\
\text { PtrLAC40 } \\
\text { PtrLAC41 } \\
\text { PtrLAC43 } \\
\text { PtrLAC44 } \\
\text { PtrLAC45 } \\
\text { PtrLAC46 } \\
\text { PtrLAC49 }\end{array}$ & $\begin{array}{l}\text { POPTR_0001s14010 } \\
\text { POPTR_0001s18500 } \\
\text { POPTR_0004s16370 } \\
\text { POPTR_0006s09830 } \\
\text { POPTR_0006s09840 } \\
\text { POPTR_0008s07370 } \\
\text { POPTR_0009s15840 } \\
\text { POPTR_0009s } 15860 \\
\text { POPTR_0010s19090 } \\
\text { POPTR_0011s12100 } \\
\text { POPTR_0016s11950 } \\
\text { POPTR_0016s11960 } \\
\text { POPTR_0019s11820 } \\
\text { POPTR_0019s11830 } \\
\text { POPTR_0019s } 11850 \\
\text { POPTR_0019s11860 } \\
\text { POPTR_0958s00200 }\end{array}$ & $\begin{array}{l}\text { Downregulation in } \\
\text { Populus trichocarpa } \\
\text { by overexpression of } \\
\text { the negative regulator } \\
\text { Ptr-MIR397a }\end{array}$ & $\begin{array}{l}12 \%-22 \% \text { reduction of } \\
\text { lignin content }\end{array}$ & 226 \\
\hline SofLAC & SCVPRZ3027A08.g & $\begin{array}{l}\text { Overexpression in } \\
\text { Arabidopsis } l a c 17 \\
\text { mutant }\end{array}$ & $\begin{array}{l}\text { Restores lignin content } \\
\text { to wild-type levels in } \\
\text { the lac } 17 \text { mutant }\end{array}$ & 227 \\
\hline ZmLAC3 & & $\begin{array}{l}\text { Overexpression in } \\
\text { maize }\end{array}$ & $\begin{array}{l}11 \%-20 \% \text { increase of } \\
\text { lignin content in mature } \\
\text { stems }\end{array}$ & 234 \\
\hline
\end{tabular}

aPeroxidase gene names are according to Peroxibase ${ }^{228}$. ${ }^{\mathrm{b}}$ Names based on the Arabidopsis nomenclature and phylogeny from Duroux and Welinder ${ }^{229}$.

Within the peroxidases, disruption of AtPrx2211, AtPrx4 ${ }^{230}$, AtPrx17212, AtPrx25211, AtPrx52 213 , or AtPrx72 231 reduces lignin content in Arabidopsis, while disruption of AtPrx71 increases the lignin S/G ratio 215 . Among these peroxidases, AtPrx2, AtPrx17, and AtPrx25, are localized to the cell wall211,212. Similarly, down-regulation of the anionic class III peroxidases PrxA3a and PtrPO21 in aspen ${ }^{218}$ and Populus trichocarpa ${ }^{217}$ respectively, and of the cationic peroxidase NtPrx60 in tobacco ${ }^{216}$, 
results in reduced lignin content, indicating a role in lignification for these enzymes. The tomato basic peroxidase tpx 1 is also involved in lignification as its overexpression results in an increase in the lignin content of leaves ${ }^{219}$. It is interesting to consider whether the peroxidases involved in lignin formation are recognisable by their sequences, i.e. whether they are closely related or belong to distinct phylogenetic clades.

Figure 10. Maximum likelihood phylogeny of rice and Arabidopsis peroxidases - overview and key to Figures 11 and 12. Clade names, where clade structure is maintained after the merger across the two species are indicated according to Duroux and Welinder ${ }^{229}$ for Arabidopsis (marked in green) and according to Passardi et al. ${ }^{209}$ for rice (marked in blue). Dashed lines indicate subclades for which enlarged and annotated views are provided in Figures 11 and 12 .

Figure 10 provides an overview of the phylogeny of rice and Arabidopsis peroxidases, while Figure 11 shows clades harboring the peroxidases listed in Table 3.

Figure 11. A-D: Expanded view of clades from Figure 10 harboring Arabidopsis peroxidases implied in lignin formation (Table 3) indicated with arrows. Color-coding as in Figure 10.

Peroxidases involved in lignin synthesis appear to be encoded by small groups of very similar genes embedded across the mixed Arabidopsis-rice clades. For laccases, truncation of BdLAC5 reduced lignin content by $10 \%$ in Brachypodium. The modest reduction observed may be explained by the 
compensatory activity of BdLAC6, another cell wall localized laccase expressed in Brachypodium stems220. Disruption of AtLAC15, a gene coding for a laccase preferentially expressed in Arabidopsis seeds, resulted in a 30\% decrease of lignin content224. Meanwhile, silencing the laccase encoded by PtLAC2, which is preferentially expressed in xylem in poplar, resulted in a change of the lignin S/G ratio but no change in lignin content, suggesting a role in the oxidation of cell wallrelated phenolics for this laccase221. Disruption of AtLAC4 or AtLAC17 in Arabidopsis reduces lignification in stems222, and localization of these laccases in secondary cell wall domains directs lignification in culture systems for xylem cell differentiation ${ }^{232}$. Simultaneous disruption of AtLAC4 and AtLAC17 reduces lignin content further compared to the single mutants222. The involvement of the sugarcane laccase, SofLAC, in lignification is supported by its expression profile in lignifying tissues and its capacity to complement the Arabidopsis lac17 mutant227. The functional redundancy of laccases for lignification is also supported by the simultaneous disruption of AtLAC4, AtLAC17, and AtLAC11 in Arabidopsis, which almost completely abolished root lignification and resulted in a growth arrest phenotype223. Interestingly, lignification of the Casparian strip, an apoplastic diffusion barrier in plants, is unaffected in this triple mutant. This corroborates the involvement of peroxidases in this precise lignification process223,214. In this process, an NADPH oxidase involved in the supply of $\mathrm{H}_{2} \mathrm{O}_{2}$ for peroxidasemediated lignification has been identified and shown to be brought into proximity of localized peroxidases through the action of Casparian strip domain proteins214. 
Deposition and maintenance of the Casparian strip in the endodermis are highly regulated processes ${ }^{233}$. Moreover, artificial microRNA knockdown of a peroxidase gene (AtPrx64) specifically in the endodermis delayed the formation of this lignified diffusion barrier214. Recently, overexpression and downregulation of the laccase GhLac1 gene in cotton resulted in an increase and a decrease of lignin content, respectively225. Increased lignin contents were also observed in maize lines that overexpress the laccase gene $Z m L A C 3^{234}$ Finally, the simultaneous downregulation of 17 laccase genes in poplar (out of 49 sequences present in the genome) via the overexpression of a microRNA resulted in reductions of both laccase activity and lignin content226.

Table 3 does not comprise any enzymes annotated to be involved in lignan crosslinking for the simple reason that these have attracted much less interest than the dirigent proteins (4.1.3) and none are known. The seminal paper on the dirigent proteins $^{235}$ implied a laccase, and an extract from Piper regnellii leaves capable of producing (+)-conocarpan, a neolignan, was observed to be devoid of detectable peroxidase activity 236 .

\subsubsection{BAHD Transferases}

Acyl transferases from the BAHD enzyme family153 have also been implicated in lignin acylation (Table 4). In this case there is no subcellular location conundrum, as was the case for xylan feruloylation. Withers et al. ${ }^{237}$ have identified a rice $p$ coumaroyl CoA:hydroxycinnamyl alcohol transferase (OsPMT) that catalyzes the coupling of $p$-coumarate with monolignols via $p$-coumaroyl-CoA (see Figure 3). 
OsPMT has a high affinity for sinapyl alcohol and $p$-coumaryl alcohol (as acyl acceptors) in vitro, yielding sinapyl-p-coumarate and $p$-coumaryl-p-coumarate. OsPMT homologs have also been identified in Brachypodium164 and maize ${ }^{238}$. Mutation of BdPMT almost completely depleted the fraction of $p$-coumarate acylating lignin, whereas overexpression both increased the amount of $p$ coumarate groups on lignin by three-fold and decreased total lignin content. Interestingly, the amount of $p$-coumarate acylating arabinosyl units on arabinoxylans was unchanged in these transgenics, highlighting the specificity of BdPMT for monolignols164. Similarly, ZmPMT was shown to use $p$-coumaroyl-CoA as a donor and monolignols as acceptors, with a strong preference for sinapyl alcohol. Downregulation of $Z m P M T$ in maize led to a reduction of $p$-coumarate attached to lignin, and decreased levels of S-units in lignin, although the lignin content remained unchanged238.

The enzyme responsible for the transfer of benzoate groups onto monolignols has not been identified at present. Such a transferase likely belongs to the BAHD enzyme family, in which several members are known to use both hydroxycinnamoyl-CoA and benzoyl-CoA as donors ${ }^{239,240}$. Interestingly, a Populus trichocarpa BAHD transferase from clade V (PtACT47) that transfers benzoyl-CoA onto coniferyl alcohol has been discovered ${ }^{241}$. Whether PtACT47 uses 4hydroxybenzoyl-CoA and sinapyl alcohol as substrates for lignin acylation remains to be determined. Alternatively, certain enzymes from the Serine CarboxyPeptidase 
Like (SCPL) acyltransferase family, whih is capable of using hydroxycinnamoyl and benzoyl glucose esters as donors, are also plausible candidates ${ }^{242}$. The enzyme responsible for the transfer of acetate groups onto monolignols for lignin acetylation also remains to be identified. An acetyl-CoA:coniferyl alcohol transferase (PhCFAT) from the BAHD family, specifically expressed in Petunia flowers, was shown to participate in the synthesis of the volatile compound eugenol $^{243}$. Overexpression of PhCFAT was conducted in poplar, aspen, Arabidopsis and tobacco in order to increase the eugenol content in these plants, but the impact on the levels of acetylation of lignin was not analyzed 244,245 . The putative acetyl-CoA:monolignol transferase of the BAHD enzyme family involved in lignin acetylation in plants such as sisal and kenaf remains to be identified. A couple of transferases that catalyze the synthesis of monolignol ferulate ester conjugates have been identified in Chinese angelica and rice $246,247$. These two enzymes, AsFMT and OsFMT1 (AT5), belong to the BAHD family. AsFMT preferentially uses feruloyl-CoA as a donor and monolignols as acceptors. Overexpression of OsFMT1 in rice and AsFMT in poplar resulted in an increase of coniferyl ferulate in lignin of transgenic plants246,247. 
Table 4: BAHDs genetically involved in lignin acylation

\begin{tabular}{|c|c|c|c|c|}
\hline $\begin{array}{l}\text { Gene } \\
\text { name }\end{array}$ & $\begin{array}{l}\text { Accession number / } \\
\text { BAHD clade }\end{array}$ & $\begin{array}{l}\text { Approach to modify } \\
\text { gene expression }\end{array}$ & Observed phenotype & Reference \\
\hline OSPMT & Os01g18744 / V & $\begin{array}{l}p 35 S \text { and } p A t C e s a 7 \\
\text { overexpression in poplar } \\
\text { and Arabidopsis, } \\
\text { respectively }\end{array}$ & $\begin{array}{l}\text { Incorporation in lignin of } \\
\text { monolignol } p \text {-coumarate } \\
\text { conjugates }\end{array}$ & 248 \\
\hline$B d P M T$ & Bradi2g36910/V & $\begin{array}{l}\text { 1) Missense mutant and } \\
\text { RNA silencing } \\
\text { 2) pZmUbil } \\
\text { overexpression in } \\
\text { Brachypodium } \\
\text { 3) pAtC4H } \\
\text { overexpression in } \\
\text { Arabidopsis }\end{array}$ & $\begin{array}{l}\text { 1) Reduction of lignin } \\
\text { bound } p \text {-coumarate } \\
\text { 2) Increase of lignin } \\
\text { bound } p \text {-coumarate and } \\
\text { S/G ratio } \\
\text { 3) Increase of lignin } \\
\text { bound } p \text {-coumarate }\end{array}$ & $\begin{array}{l}164 \\
249\end{array}$ \\
\hline$Z m P M T$ & BT042717.1 / V & RNA silencing & $\begin{array}{l}\text { Reduction of cell-wall } \\
\text { bound } p \text {-coumarate and } \\
\text { lignin S units }\end{array}$ & 238 \\
\hline$A s F M T$ & AHL24755.1 / III & $\begin{array}{l}p 35 S \text { and } p P t C e s a 8 \\
\text { overexpression in poplar }\end{array}$ & $\begin{array}{l}\text { Incorporation in lignin of } \\
\text { monolignol ferulate } \\
\text { conjugates. Slight } \\
\text { increase of lignin S units }\end{array}$ & 246 \\
\hline $\begin{array}{l}\text { OsFMT1 } \\
\text { /AT5 }\end{array}$ & Os05g19910/V & $\begin{array}{l}\text { Activation tagging and } \\
\text { pZmUbil overexpression }\end{array}$ & $\begin{array}{l}\text { Incorporation in lignin of } \\
\text { monolignol ferulate } \\
\text { conjugates }\end{array}$ & 247 \\
\hline
\end{tabular}

\subsubsection{Dirigent Proteins}

Dirigent (DIR) proteins mediate regio- and stereoselective coupling of two phenoxy radicals generated by laccases or peroxidases during lignan biosynthesis. As examples, a DIR protein discovered in Forsythia suspensa ${ }^{250}$ direct the coupling of coniferyl alcohol radicals to give the 8,8'-linked lignan dimer (+)-pinoresinol, whereas AtDIR6 from Arabidopsis favors the formation of the 8,8'-linked dimer (-)pinoresinol 251 . Such selective coupling of radicals is not observed in the absence of DIR proteins: The activity of laccases or peroxidases alone towards coniferyl alcohol molecules result in a racemic mixture of approximately equal amounts of (+/-) 8,8'-, (+/-) 8,5'-, and 8-O-4'-linked products251. DIR proteins have been 
suggested to be involved in lignin biosynthesis by directing the polymerization of coniferyl alcohol 252,253 , but so far, strong evidence for the participation of DIR proteins in the biosynthesis of lignin is missing. The exact function of lignans (8-8linked monomers) and neolignans (8-5- or 5-5-linked monomers) in plants is not fully resolved, and their incorporation into lignin has never been evidenced. The occurrence of glycosylated lignans in the vacuole suggests their intracellular relocation, rather than crosslinking to cell wall components following synthesis in the apoplast22. Nevertheless, cotton plants overexpressing a DIR-like gene showed a higher accumulation of lignin in the epidermis and vascular bundles of leaves ${ }^{254}$, whereas disruption of Pinoresinol Reductase 1 (PrR1) in Arabidopsis leads to decreased lignin content in stems ${ }^{255}$, and a protective role against lignification-induced oxidative damage has been proposed for such reductases ${ }^{256}$. Finally, although not considered to be involved in the lignification of xylem vessels and fibers, one DIR domain-containing protein (AtDIR10) has been implicated in lignin synthesis in the Casparian strip in the root of Arabidopsis, but its function remains speculative ${ }^{257}$.

\subsection{Peroxidases in extensin cross-linking}

Both the formation of intra- and interchain cross-links in extensins are generally thought to be catalyzed by peroxidases. Fry149 demonstrated that isodityrosine (the intra-chain link) could be formed by peroxidase isoforms. Cross-linking to yield di-isodityrosine interchain cross-links is also catalyzed by peroxidases as demonstrated in elegant experiments ${ }^{258}$ in which the substrates - glycopeptide 
modules featuring isodityrosine moieties - were produced using synthetic modules expressed in planta followed by cross-linking in vitro using an extensin peroxidase purified from tomato suspension cultures. The in vivo situation was addressed using NMR showing that di-isodityrosine cross-links were at the limit of detection ${ }^{259}$. Four extensin peroxidases have been biochemically characterized and cloned. The sequence of one of these, GvEP1 from grapevine ${ }^{260,261}$, has been lost. Biochemical evidence for the activity of the grapevine enzyme is strong and the Vitis vinifera genome comprises peroxidases that are very closely related to the three other extensin peroxidases. These are included in table 5, and in Figure 12.

Figure 12. A and B: clades of Figure 10 comprising biochemically characterized extensin peroxidases (Table 5) indicated with arrows. Colour-coding as in Figure 10.

The CG5 peroxidase in tomato, Solyc02g094180262, has been shown to cross-link EXTs under physiological conditions. Lupin LEP1 peroxidase ${ }^{263}$ and its close relative from French bean, FBP1264, have been shown to cross-link extensins in vitro, but at a $\mathrm{pH}$ higher than normally found in the apoplast, and the two peroxidases were hypothesized to be activated in response to external stress stimuli.

The existence of peroxidases dedicated to extensins is not a priori necessary, but it is striking that the three characterized extensin peroxidases (and their putative grapevine orthologs) occupy subclades with no rice sequences and with no peroxidases implied in lignin formation (see Figure 12), suggesting specialization 
and labour division among peroxidases. No Arabidopsis peroxidase(s) has been experimentally shown to cross-link EXT YXY motifs. It is possible that enzyme mass may correlate negatively with glycan decoration and that a higher isoelectric point may provide increased mobility within the cell wall allowing the peroxidase to more easily access the dense secondary cell wall 231 .

Table 5 includes the most similar Arabidopsis sequences to the three characterized extensin peroxidases. Expression of Arabidopsis peroxidases related to the tomato enzyme correlates to some degree with extensin expression, but extensin expression and expression of the enzymes responsible for post-translational modifications of extensins are generally not correlated191. Furthermore, given the role of extensins and cell wall cross-linking in pathogen defense ${ }^{265}$, expression patterns of peroxidases often reflect this biological function, as exemplified by Prx37 in Table 5. 
Table 5: Peroxidases demonstrated to be involved in extensin cross-linking or implied to be by phylogeny

\begin{tabular}{|c|c|c|c|c|}
\hline Gene name & $\begin{array}{l}\text { Accession number } \\
\text { / alternative name } \\
\text { (group) }^{\mathrm{a}}\end{array}$ & $\begin{array}{l}\text { Approach to characterize } \\
\text { enzyme or modify gene } \\
\text { expression }\end{array}$ & $\begin{array}{l}\text { Observed } \\
\text { phenotype / } \\
\text { Function / } \\
\text { Expression/ } \\
\text { Other } \\
\end{array}$ & Reference \\
\hline $\begin{array}{l}\text { CG5 } \\
\text { (tomato extensin } \\
\text { peroxidase pI } \\
4.6)\end{array}$ & Solyc02g094180 & Heterologous expression in E.coli & $\begin{array}{l}\text { Covalently } \\
\text { crosslinked } \\
\text { tomato P1 } \\
\text { extensin and P3- } \\
\text { type extensin } \\
\text { analogs in vitro }\end{array}$ & 262 \\
\hline AtPrx35 & $\begin{array}{l}\text { AT3G49960.1/ } \\
\text { AtP21 (M) }\end{array}$ & & & \\
\hline AtPrx 50 & $\begin{array}{l}\text { AT4G37520.1/ } \\
\text { AtP9 (M) }\end{array}$ & & & \\
\hline AtPrx 16 & $\begin{array}{l}\text { AT2G18980.1/ } \\
\text { AtP22 (M) }\end{array}$ & & & \\
\hline AtPrx 55 & $\begin{array}{l}\text { AT5g14130.1/ } \\
\text { AtP20 (M) }\end{array}$ & & & \\
\hline $\begin{array}{l}\text { LEP1 Lupinus } \\
\text { albus (Lupin) }\end{array}$ & AF403735 & Purified from vegetative organs & $\begin{array}{l}\text { Apoplastic } \\
\text { extensin cross- } \\
\text { linking activity } \\
\text { in vegetative } \\
\text { organs }\end{array}$ & 263 \\
\hline $\begin{array}{l}\text { FBP 1- } \\
(\text { French Bean } \\
\text { Peroxidase 1) }\end{array}$ & $\begin{array}{l}\text { AAD37427 } \\
(\text { AF149277_1) }\end{array}$ & Expressed in Pichia pastoris & $\begin{array}{l}\text { FBP1 covalently } \\
\text { crosslinked } \\
\text { tomato P1 } \\
\text { extensin and P3- } \\
\text { type extensin } \\
\text { analogs in vitro. } \\
\text { FBP1 and other } \\
\text { members of the } \\
\text { family, were all } \\
\text { induced in cell } \\
\text { cultures by } \\
\text { elicitors }\end{array}$ & 264 \\
\hline $\operatorname{AtPrx} 22$ & $\begin{array}{l}\text { AT2G38380/ } \\
\text { AtPEa (A) }\end{array}$ & $\begin{array}{l}\text { Supressed expression in roots by } \\
\mathrm{Zn}^{2+}\end{array}$ & & 266 \\
\hline $\operatorname{AtPrx} 23$ & $\begin{array}{l}\text { AT2G38390/ } \\
\text { AtP34 (A) }\end{array}$ & & & \\
\hline AtPrx32 & $\begin{array}{l}\text { AT3G32980 / } \\
\text { AtP16 (A) }\end{array}$ & & & \\
\hline $\operatorname{AtPrx} 37$ & $\begin{array}{l}\text { AT4G08770 / } \\
\text { AtP38 (A) }\end{array}$ & $\begin{array}{l}\text { AtPrx37 promotor::GUS } \\
\text { expression;35S::AtPrx37 over } \\
\text { expression; Ectopic over } \\
\text { expression and knock out of } \\
\text { transcription factor DEWAX }\end{array}$ & $\begin{array}{l}\text { Constitutive over } \\
\text { expression } \\
\text { confers a dwarf } \\
\text { phenotype, } \\
\text { delayed } \\
\text { development and } \\
\text { an increase in the } \\
\text { amount of } \\
\text { esterified } \\
\text { phenolic material }\end{array}$ & $\begin{array}{l}261 \\
267\end{array}$ \\
\hline
\end{tabular}




\begin{tabular}{|l|l|l|l|l|}
\hline & & & $\begin{array}{l}\text { associated with } \\
\text { their walls. }\end{array}$ & \\
\hline AtPrx38 & AT4G08780/(A) & $\begin{array}{l}\text { Ectopic over expression of } \\
\text { transcription factor DEWAX }\end{array}$ & $\begin{array}{l}\text { Over expression } \\
\text { of PRX38 leads } \\
\text { to increased } \\
\text { expression of the } \\
\text { transcription } \\
\text { factor DEWAX }\end{array}$ & 267 \\
\hline AtPrx58 & $\begin{array}{l}\text { AT5G19880/ } \\
\text { AtP42 (A) }\end{array}$ & & & \\
\hline AtPrx54 & $\begin{array}{l}\text { AT5G06730/ } \\
\text { AtP29 (A) }\end{array}$ & & & \\
\hline
\end{tabular}


4.3 Peroxidases involved in cross-linking of feruloylated GAX As with extensin peroxidases, it is not a given that specialized peroxidases are required to form ferulate cross-links. In fact, to the best of our knowledge, no peroxidase has yet been associated specifically with GAX cross-linking. However, pronounced differences in GAX cross-linking activity have been found between enzymes secreted by maize suspension cultures and horseradish peroxidases, indicative of a specialization of peroxidases122,268. In rice, OsPrx110-114 have been implicated in ferulate cross-linking, however solely based on their expression profiles $^{268}$. While in vitro activity is still missing it is interesting that these peroxidases belong to clade IV3, one of the clades with no Arabidopsis accessions. It should be noted however that Figure 9 comprises several clades or sub-clades that are found only in rice.

\section{Cross-linking enzymes in biotechnology}

\subsection{Fiber cell composites}

Cross-linking enzymes (e.g. oxidase-type enzymes) as an emerging tool have gained increasing attention in relation to fabrication of green cellulose-based materials, such as composites and hydrogels. A composite is a multi-phase material that exhibits a significant proportion of the properties of the constituent phases in such way that an improved combination of mechanical characteristics, such as stiffness, toughness, and ambient and high-temperature strength, is created ${ }^{269}$. Many composite materials are composed of just two phases: a continuous phase (the matrix), which surrounds the reinforcing material (dispersed 
phase). In principle, the mechanical properties of composite materials are dependant on both the fibers and the interfacial properties between the matrix and the reinforcement phase. In the cellulose-based composites discussed here, the dispersed phase of reinforcement refers to different types of cellulose fibers (e.g. whole fiber cells, microcelluloses and nanocelluloses), while the matrix can be any polymeric material.

Oxidase enzymes (i.e. laccases and peroxidases) are the most commonly used enzymes in cellulose-based material fabrication in order to improve their mechanical and physical properties and reduce the consumption of synthetic polymers. In general, oxidase enzymes have three different roles in cellulose-based material fabrication (Table 6): (1) Polymerization and cross-linking of lignin or other phenols in lignocellulosic materials to enclose cellulose fibers in the lignified or cross-linked network ${ }^{270}$; (2) Enzyme-catalyzed grafting of hydrophobic chemical agents $^{271,272}$ (e.g. alkyl gallate and lauryl gallate) onto the surface of cellulosic fibers to enhance the compatibility between fibers and hydrophobic polymers; (3) Enzyme-catalyzed grafting of germicidal agents or antimicrobial compounds (e.g. natural phenols, chitosan and catechin) onto the surface of cellulosic fibers to develop or to improve antimicrobial properties of fibers286,273. 
Table 6 Application of oxidase enzymes in lignocellulosic materials.

\begin{tabular}{|c|c|c|c|c|c|c|}
\hline $\begin{array}{l}\text { Lignocellulosic } \\
\text { material }\end{array}$ & Enzyme & Matrix polymer & $\begin{array}{l}\text { Chemicals used for } \\
\text { fiber surface } \\
\text { modification }\end{array}$ & $\begin{array}{l}\text { Manufacturing } \\
\text { process }\end{array}$ & $\begin{array}{l}\text { Role of laccase } \\
\text { treatment }\end{array}$ & Reference \\
\hline Hemp bast fiber & $\begin{array}{l}\text { Laccase (Trametes } \\
\text { versicolor) }\end{array}$ & Epoxy & l & $\begin{array}{l}\text { Vaccum infusion } \\
\text { moulding }\end{array}$ & $\begin{array}{l}\text { Polymerization and } \\
\text { crosslinking of lignin }\end{array}$ & 274 \\
\hline Plantain fiber & $\begin{array}{l}\text { Laccase (Aspergillus } \\
\text { oryzae) }\end{array}$ & $\begin{array}{l}\text { None (self-bonding } \\
\text { board) }\end{array}$ & l & Hot pressing & $\begin{array}{l}\text { Polymerization and } \\
\text { crosslinking of lignin }\end{array}$ & 275 \\
\hline $\begin{array}{l}\text { Hemp hurds and } \\
\text { flax shives }\end{array}$ & $\begin{array}{l}\text { Laccase (Aspergillus } \\
\text { sp.) }\end{array}$ & $\begin{array}{l}\text { None (self-bonding } \\
\text { board) }\end{array}$ & l & Hot pressing & $\begin{array}{l}\text { Polymerization and } \\
\text { crosslinking of lignin }\end{array}$ & 276 \\
\hline Jute fiber & $\begin{array}{l}\text { Laccase (Trametes } \\
\text { versicolor) }\end{array}$ & Polypropylene & l & Hot pressing & $\begin{array}{l}\text { Polymerization and } \\
\text { crosslinking of lignin }\end{array}$ & 277 \\
\hline Kraft pulp & $\begin{array}{l}\text { Laccase (Trametes } \\
\text { pubescens) }\end{array}$ & Ultra-filtered lignin & l & $\begin{array}{l}\text { Cold pressing } \\
\text { followed by hot } \\
\text { pressing }\end{array}$ & $\begin{array}{l}\text { Polymerization and } \\
\text { crosslinking of lignin }\end{array}$ & 278 \\
\hline Rubber wood fiber & Laccase & $\begin{array}{l}\text { Hydrolyzed lignin or } \\
\text { urea formaldehyde }\end{array}$ & l & $\begin{array}{l}\text { Cold pressing } \\
\text { followed by hot } \\
\text { pressing }\end{array}$ & $\begin{array}{l}\text { Polymerization and } \\
\text { crosslinking of lignin }\end{array}$ & 279 \\
\hline Jute fiber & $\begin{array}{l}\text { Laccase (Aspergillus } \\
\text { sp.) }\end{array}$ & Polypropylene & Alkyl gallate & $\begin{array}{l}\text { Hand lay-up followed } \\
\text { by hot pressing }\end{array}$ & $\begin{array}{l}\text { Polymerization and } \\
\text { crosslinking of lignin }\end{array}$ & 280 \\
\hline Wood fiber & Peroxidase SP 502 & $\begin{array}{l}\text { None (self-bonding } \\
\text { board) }\end{array}$ & l & Hot pressing & $\begin{array}{l}\text { Polymerization and } \\
\text { crosslinking of lignin }\end{array}$ & 281 \\
\hline $\begin{array}{l}\text { Microfibrillated } \\
\text { cellulose }\end{array}$ & $\begin{array}{l}\text { Laccase (Trametes } \\
\text { versicolor) }\end{array}$ & Glycerol & $\begin{array}{l}\text { Galactoglucomannan- } \\
\text { lignin network }\end{array}$ & $\begin{array}{l}\text { Gelation followed by } \\
\text { solution casting }\end{array}$ & $\begin{array}{l}\text { Polymerization and } \\
\text { crosslinking of lignin }\end{array}$ & 282 \\
\hline $\begin{array}{l}\text { Cellulose } \\
\text { nanocrystals }\end{array}$ & $\begin{array}{l}\text { Laccase (Pycnoporus } \\
\text { cinnabarinus) }\end{array}$ & l & $\begin{array}{l}\text { Feruloylated } \\
\text { arabinoxylan oligomers }\end{array}$ & $\begin{array}{l}\text { Gelation followed by } \\
\text { solution casting }\end{array}$ & $\begin{array}{l}\text { Polymerization and } \\
\text { crosslinking of phenols }\end{array}$ & $\begin{array}{l}283 \\
284\end{array}$ \\
\hline Kraft pulp & $\begin{array}{l}\text { Laccase (Trametes } \\
\text { villosa) }\end{array}$ & I & Lauryl gallate & l & $\begin{array}{l}\text { Hydrophobization of } \\
\text { cellulose fiber }\end{array}$ & 285 \\
\hline Linen fiber & $\begin{array}{l}\text { Laccase (Ascomycete } \\
\text { myceliophthora } \\
\text { thermohpila) }\end{array}$ & l & Chitosan and catechin & l & $\begin{array}{l}\text { Grafting germicidal } \\
\text { agents onto fiber surface }\end{array}$ & 286 \\
\hline Flax pulp & $\begin{array}{l}\text { Laccase (Pycnoporus } \\
\text { cinnabarinus) }\end{array}$ & l & $\begin{array}{l}\text { Syringaldehyde } \\
\text { acetosyringone } \\
p \text {-coumaric acid }\end{array}$ & I & $\begin{array}{l}\text { Grafting natural phenols } \\
\text { onto fiber surface }\end{array}$ & 287 \\
\hline
\end{tabular}


Oxidase enzymes have long been used to produce medium-density (MDF) and high-density fiberboards (HDF) from wood fiber or pulp either with fewer or completely without binders (e.g. urea-formaldehyde). Oxidase enzymes catalyze cross-linking of lignin moieties and covalent binding of the phenolic compounds to wood fiber. As such, binder-less or binder-free fiberboards can be made via hotpressing after enzyme treatment $275,288,281,289,281,290$. It has been found that binder-less and binder-free fiberboards have comparable mechanical properties with traditional fiberboards. In general, the concept of using oxidase enzymes to produce binder-less fiberboards not only reduces consumption of synthesis binders but also aims to modify cellulose fiber surfaces to increase the hydrophobicity of the fibers and, therefore, improve the compatibility between the fibers and matrix polymers (e.g. lignin or synthetic binder).

Grafting of hydrophobic chemical agents onto jute fabric by laccase has been accomplished using gallate carrying linear alkyl chains of different lengths 280 . The hydrophobicity of the jute fibers was assessed by measuring the water contact angle, which increased from $106.61^{\circ}$ in the control fibers to $117.54^{\circ}, 121.70^{\circ}$, and $133.01^{\circ}$ respectively for gallates carrying alkyl chains of length 3,8 , and 12 carbons. Consequently, water absorption of fibers decreased from about 25 weight percent in the control fibers to about 20 in the treated fibers, and improved interfacial bonding between fibers and polypropylene (PP) was achieved in jute/PP composites 280 . 
Fillat et al.287 attempted to graft different phenolic compounds, including syringaldehyde, acetosyringone and $p$-coumaric acid, onto the surface of unbleached flax fibers using laccases to obtain fibers with improved antimicrobial properties. All treated fibers showed antimicrobial activity in inhibiting the growth of Staphylococcus aureus, Pseudomonas aeruginosa and Klebsiella pneumonia, and acetosyringone and $p$-coumaric acid grafted fibers showed a high antibacterial activity against $K$. pneumonia compared to syringaldehyde-grafted fibers.

\subsection{Cellulose nanofibril composites}

The demand for green materials with functionality, uniformity, and high mechanical strength-to-weight performance is increasing. These qualities cannot be achieved in materials based on whole fiber cells. Instead, cellulose nanofibrils with a width below $100 \mathrm{~nm}$ can be derived from the plant cell wall and used to form nanostructured materials ${ }^{291,292}$. Compared to whole fiber cells, cellulose nanofibrils (high purity of cellulose) contain no structural elements from plants other than the cellulose microfibril. The intra- and inter-chain hydrogen bonds make such fibrils remarkably stiff and stable. Crystalline cellulose fibrils have been estimated to have an axial elastic modulus greater than Kevlar, as well as low density 293 . Due to their inherent strength and self-interacting properties, cellulose nanofibrils have shown a strong reinforcement effect in composite materials made with various polymer-matrices ${ }^{294,295}$. However, the performance of these materials is still far from the theoretical potential of the fibrils. A major bottleneck is the hydrophilicity of cellulose which causes poor fibril-matrix adhesion and agglomeration during formation of composites. These problems may partly be overcome by chemical 
introduction of functional groups to the surface of cellulose. However, altering the chemistry of cellulose ultimately has negative effects on its structural stability and interactions within a final composite ${ }^{295}$.

The plant cell wall supposedly achieves cellulose-matrix adhesion using an alternative approach by bridging via other biopolymers. Therefore, a biomimetic approach has been explored where functional groups were enzymatically and chemically introduced into xyloglucans, potentially allowing cellulose to be indirectly attached to a hydrophobic polymer ${ }^{296,297}$. More recently, bioinspired materials have been developed based on evidence that complex networks between hemicelluloses and lignin can be synthesized in vitro using laccase 282,298 . It has further been shown that cellulose nanofibrils can be entrapped in the formed hemicellulose-lignin network enabling the synthesis of composites and films ${ }^{298,282}$. These authors further reported that they made barrier films and composites from cellulose, the galactoglucomannan-lignin network, and glycerol. Nanofibrils, produced from carboxymethylated cellulose, were first mixed with galactoglucomannan-lignin, and then cross-linked between lignin-moieties with laccases to enclose cellulose in the formed networks. Finally, the composites were produced by reinforcing the formed cellulose-hemicellulose-lignin networks in a plasticizer. Even though the material strength and stiffness were not on par with plant cell walls, the materials exhibited low oxygen permeability.

In a similar approach, bioinspired assemblies of secondary cell walls were made from cellulose nanofibrils and ferulic acid-substituted arabinoxylans283. Laccase 
was used to cross-link the ferulic acids and thus embed the cellulose nanofibrils in a matrix. This study did not comprise the mechanical properties of the materials. Instead, the mobility of fluorescent probes and cellulose binding domains within the assemblies were examined to reveal features influencing enzymatic activity on lignocellulosic biomass 283,284.

\subsection{Hydrogels}

Hydrogels are insoluble polymer networks that can retain large amounts of water upon formation. Hydrogel technology is applied to a wide range of applications, such as drug delivery systems, tissue engineering, food additives etc. ${ }^{299}$. Additional chemical cross-linking of the polymers in the hydrogels is sometimes necessary to make a robust hydrogel, for example when used as support-material in damaged tissue. Among in-organic polymers, proteins, and polysaccharides, cellulose is considered an excellent polymer for preparing hydrogels due to its hydrophilicity, abundance, non-toxicity, and biocompatibility ${ }^{300}$. In addition, the surface chemical properties of cellulose provide possibilities for functionalization. For example, covalent incorporation of tyramine onto carboxymethyl cellulose was achieved via formation of di-tyrosine cross-linked hydrogels. Cross-link formation was catalysed by horseradish peroxidase and hydrogen peroxide. As di-tyrosine cross-linked hydrogels can be formed under mild conditions with minimal side reactions, there is potential for making these materials in situ, e.g. for incorporation of cells or tissue re-generation ${ }^{301}$.

Pectin has also been used in synthesis of hydrogels. A number of studies have been conducted to improve the viscosity and gelling performance of sugarbeet 
pectin. The major deficiency of sugar beet pectin is a very low average molecular mass of 10000 Dalton, compared to, for example, lime pectin which has an average mass of 150000 Dalton. Sugarbeet pectin is rich in RGI encompassing ester bound ferulic acid residues on the side-chains (Figure 4). Sugarbeet pectin has been extracted by an enzymatic process using commercial enzymes (Driselase or SP584) affording low molecular mass fractions. Arabinan side chains are very sensitive to acid extraction but mild enzyme-based extraction procedures may preserve the structure of the arabinan chains and give rise to appreciable number of arabinan chains with high ferulic acid content. Several studies have used this arabinan fraction for oxidative cross-linking ${ }^{302,303,}$. The feruloylated arabinan contains 2-14 arabinose residues, and 1 to 2 feruloylated residues on each chain after separation on a feruloylated affinity column. When this mixture of feruloylated arabinans was subjected to oxidative reaction (horseradish peroxidase and $\mathrm{H}_{2} \mathrm{O}_{2}$ ), the content of monomeric feruloyl residues declined while di-ferulic residues increased. The product also expressed high-gelling and high-viscosity performance, which has commercial interest.

\section{Cleaving and engineering cross-links}

Lignin represents a very large resource of aromatic feedstock for a wide variety of applications. Lignin depolymerization with the aim of exploiting its building blocks involves mainly non-enzymatic catalysis and has recently been reviewed ${ }^{304}$. For other applications the cleavage of lignin inter-unit linkages is relevant as a means of overcoming biomass recalcitrance. It is of interest, for example, in the manufacture of nanocellulose for advanced biomaterials (preceeding section) and in biofuel 
production. Harsh chemical treatments, usually with hypochlorite, are common in nanocellulose production. Environmentally friendly enzyme-mediated alternatives are desirable ${ }^{305}$ and relevant in an attempt to overcome the recalcitrance of biomass also for biofuel production. Ester bonds between polysaccharides and phenolic moieties are by far the most labile. However, they make up a minor proportion of the bonds found in cross-linked material. Ether bonds are much more common in phenolic cross-links but cleaving these requires stronger agents. As such, it is attractive to introduce more labile bonds into biopolymers in order to improve biomass for biofuel production.

6.1 Feruloylesterases as auxiliary enzymes In transgenic tall fescue (Festuca arundinacea) or wheat overexpressing the Aspergillus niger ferulic acid esterase gene (faeA), a reduction of esterified ferulates was observed ${ }^{306,307}$. In a subsequent experiment, larvae of the leaf grazing fall armyworm (Spodoptera frugiperda) were fed leaves of the transgenic tall fescue. Larvae growth, mortality and food utilization were found to negatively correlate with the degree of feruloylation in the transgenic leaves ${ }^{308}$. The aim of these studies was to modify the cell wall in order to improve its degradability and increase its solubility and extractability. Ferulates were cleaved off from the polysaccharide chain either in muro or during their transport through the Golgi. Potential drawbacks to utilizing such approaches are the phenotypic consequences on the plant yield306. 


\section{$\underline{6.2 \text { Reduction of lignin-xylan linkages }}$}

Several studies have documented the occurrence of $\gamma$-ester linkages between hydroxyl groups from lignin building blocks and glucuronic acids from glucuronoarabinoxylans in pine, birches, and beechwood ${ }^{309,310}$. Glucuronoyl esterases (EC 3.1.1.-) are accessory enzymes that act on the esters of 4-O-methylD-glucuronic acid (MeGlcA), which are grouped into the Carbohydrate Esterase (CE) family 15 according to the CAZy classification112,311. Expression of genes encoding CE15 enzymes was attempted in Arabidopsis and hybrid aspen to reduce the presence of lignin-xylan crosslinks and hereby improve biomass saccharification. Counterintuitively, transgenic aspen that expressed a gene encoding a cell-wall targeted version of a CE15 from the white-rot basidiomycete Phanerochaete carnosa (PCGCE) showed higher lignin content $(+40 \%)$ and a reduced amount of cellulose and MeGlcA groups. Nevertheless, saccharification of the biomass after acid pretreatment resulted in an increase in cellulose conversion in the transgenic lines, indicating that intermolecular cross-linking targeted by PcGCE inhibits the enzymatic digestibility of lignocellulose ${ }^{312}$. These results partially corroborate the results from an original study on the heterologous expression of PcGCE in Arabidopsis cell walls ${ }^{313}$. In this study, transgenic Arabidopsis plants displayed reduced glucose and xylose content, as well as reduced cell wall thickness in the interfascicular fibres. Interestingly, xylose recovery was improved despite the fact that the content of insoluble lignin was unchanged.

\section{$\underline{6.3 \text { Lignin modifying enzymes }}$}


Cleavage of phenolic cross-links in nature is mainly observed in the context of wood-decaying processes mediated by fungi and bacteria ${ }^{377}$. Next to a whole battery of polysaccharide-degrading enzymes (e.g. cellulases, hemicellulases, and pectinases), some fungi and bacteria express genes encoding oxidative enzyme systems, which predominantly serve to solubilise lignin in the plant cell wall to increase accessibility to, and enable hydrolysis of, cellulose and hemicelluloses. Most wood-decaying fungi are not able to grow on lignin ${ }^{314,315}$. However, there are examples of both fungi and bacteria that rely on lignin as their sole carbon source (Table 7).

Table 7. Lignolytic microorganisms

\begin{tabular}{|c|c|c|}
\hline Taxa & Phylum & References \\
\hline Aspergillus sp. & Fungi & $\begin{array}{l}316 \\
317\end{array}$ \\
\hline $\begin{array}{l}\text { Achremonium sp Fusarium } \\
\text { oxysporum Trichoderma sp } \\
\text { Verticillium sp Verticillium sp } \\
\text { Trichocladium canadense }\end{array}$ & Fungi & 316 \\
\hline Phoma herbarum & Fungi & 318 \\
\hline Bacillus sp. & Bacteria & $\begin{array}{l}319 \\
320\end{array}$ \\
\hline Aneurinibacillus aneurinilyticus & Bacteria & 321 \\
\hline Burkholderia sp. & Bacteria & $\begin{array}{l}322 \\
319\end{array}$ \\
\hline $\begin{array}{l}\text { Serratia sp., Pseudomonas } \\
\text { chlororaphis, Stenotrophomonas } \\
\text { maltophilia, Mesorhizobium sp. }\end{array}$ & Bacteria & 323 \\
\hline Acinetobacter sp. & Bacteria & 324 \\
\hline Tolumonas lignolytica & Bacteria & 325 \\
\hline Oceanimonas doudoroffii & Bacteria & 326 \\
\hline $\begin{array}{l}\text { Aquitalea sp., Cupriavidus sp., } \\
\text { Gordonia sp., Paenibacillus sp. }\end{array}$ & Bacteria & 319 \\
\hline Enterobacter lignolyticus & Bacteria & 327 \\
\hline
\end{tabular}




\begin{tabular}{|l|c|l|}
\hline Pandoraea sp. & Bacteria & 328 \\
\hline Comamonas $s p$. & Bacteria & 329 \\
\hline
\end{tabular}

Lignin-degrading peroxidases are mainly found in class II of non-animal hemeperoxidases, which are comprised of secreted fungal peroxidases ${ }^{330}$. Among those peroxidases four subgroups are defined: $(A)$ lignin peroxidases (LiP), (B) manganese peroxidases $(\mathrm{MnP}),(\mathrm{C})$ versatile peroxidases $(\mathrm{VP})$, and $(\mathrm{D})$ dyedecolorizing peroxidases (DyP). These are heme-dependent enzymes with a high redox-potential of $0.8-1.5 \mathrm{~V}$ and a relatively broad substrate specificity; active on phenolic substrates, nonphenolic lignin model compounds and a range of organic compounds in the presence of $\mathrm{H}_{2} \mathrm{O}_{2} 314$.

Figure 13. The mechanism of radical mediated lignin depolymerisation. The reaction can be started either by a peroxidase or by a laccase-mediator-system (LMS). Black structures in the bracket represent radical resonance structures. Blue structures are linked to polymeric lignin while red structures are released degradation products.

Laccases are another class of lignolytic enzymes and are present in all life kingdoms. They are grouped into true fungal sensu stricto laccases, fungal pigment multicopper oxidases, fungal ferroxidases, ascorbate oxidases, and plant and insect laccases. Laccases are copper-dependent enzymes with a broad substrate range and a slightly lower redox potential of $0.3-0.8 \mathrm{~V}$ compared to the peroxidases205. Laccases usually catalyze the formation of phenoxy radicals 
through removal of a single electron from a phenolic hydroxyl group along with reduction of $\mathrm{O}_{2}$ to $\mathrm{H}_{2} \mathrm{O}$. Radical mediated lignin cleavage is outlined in Figure 13 . Upon radical generation in the lignin several reactions may occur: ring cleavage, demethoxylation, benzylic oxidation, $\beta-\mathrm{O}-4$ cleavage or $\alpha-\beta$ scission $^{205}$. Recent thermodynamic considerations appear to support the hypothesis that laccases alone are insufficient to catalyze lignin cleavage ${ }^{331}$. In contrast, recent EPR studies on laccase activity on lignin revealed that these are indeed able to generate radicals in lignin, and that the redox potential is not predictive of the reaction efficiency: The laccase from Myceliophthora thermophila (redox potential 0.4 V) showed a somewhat higher radical generation rate in lignin than the laccase from Trametes versicolor (redox potential $0.8 \mathrm{~V})^{332}$. Nevertheless, the use of a so-called laccase mediator system is considered to catalyze bond cleavage in lignin substrates205. The laccase-mediator interactions may explain why some lignindegrading microorganisms do not possess peroxidase-encoding genes in their genomes. For the brown rot basidiomycete Postia placenta, it was shown that laccases expressed by the fungus utilized 2,5-dimethoxyhydroquinone as a mediator for reduction of $\mathrm{Fe}^{3+}$ to $\mathrm{Fe}^{2+}$ with concomitant $\mathrm{H}_{2} \mathrm{O}_{2}$ production. Hydroxyl radicals $(\bullet \mathrm{OH})$ generated via the Fenton reaction were then, due to their small size, able to diffuse into the plant cell wall to start the radical reaction necessary to degrade lignin and cellulose ${ }^{333}$ (Figure 13). In the natural eco-systems involved in carbon turnover of the complex plant cell wall matrix, fungi and bacteria form a complex synergistic and competitive community, in which they not only compete for 
nutrients but also for space. The extent of the complexity of the interactions in this process is far from understood. Data based on DNA-sequencing shows that fungi dominate the decomposition in the upper soil horizons, while bacteria are more important in deeper ones ${ }^{334}$. This synergistic action was recently demonstrated using a laccase as an isolated enzyme and a soil bacterium ${ }^{335}$. Bacterial growth on lignin was significantly improved when a laccase was added to the cultivation medium. The addition of reactants for the Fenton reaction led to further improvement of growth. A comprehensive overview of the enzymes, these organisms and their evolution has been provided by Janusz and colleagues ${ }^{336}$.

\subsection{Engineering inter-unit linkages in lignin}

Modification of inter-unit linkages within lignin is a promising approach to alter lignin structure and reduce its recalcitrance during biomass pretreatments. These modifications may be carried out in ways that do not compromise agronomic performance. Engineering plants for the expression of endogenous laccases represents one such strategy to enhance biomass quality ${ }^{337}$. The downregulation of laccase enzymes involved in lignin formation resulted in an improvement of biomass saccharification efficiency in Arabidopsis222, Brachypodium220, and poplar221. Modification of lignin by incorporation of non-canonical monomers has also showed promising results $338,339,126$. In particular, incorporation of hydroxycinnamate esters, such as coniferyl ferulate, into the lignin backbone of poplar by overexpressing a feruloyl-CoA:monolignol transferase (FMT) enhanced both biomass saccharification efficiency and chemical pulping246,340,341. 
These positive results are attributed to a higher degree of readily cleavable ester linkages present in the lignin backbone due to the incorporation of the hydroxycinnamate ester. Similar results have been achieved by incorporation of rosmarinic acid (another hydroxycinnamate ester) within lignin as previously illustrated in vitro ${ }^{84}$. Incorporation of catechol (e.g., caffeyl and 5-hydroxyconiferyl alcohols) represents another approach to reduce biomass recalcitrance. Indeed, catechol groups reduce the formation of benzyl ether and ester cross-links between hemicelluloses and lignin during the $\beta-O-4$ coupling of monomers due to internal trapping of the quinone radical intermediate and formation of benzodioxane structures $^{342,343}$. Moreover, linear lignin polymers consisting of benzodioxane units may have properties that make them amenable for use in value-added products, such as lignin-based carbon fibers ${ }^{344}$.

Interfering with the elongation process of lignin chains has been successfully demonstrated to enhance biomass utilization. To this end, in planta synthesis of monomers that lack either a $\beta$-carbon or a free para-hydroxyl group have been achieved $^{345,346}$. For example, expression in Arabidopsis of a Pseudomonas fluorescens hydroxycinnamoyl CoA hydratase-lyase generated plants that accumulated hydroxybenzaldehydes, which are known to form end groups in lignins ${ }^{80,345}$. The resulting transgenic plants contained lignins with shorter chains and showed increased biomass digestibility. A similar result might be obtained through expression of the gene encoding vanillin synthase, which catalyzes the conversion of ferulic acid into vanillin ${ }^{347,348,349}$. An isoeugenol O-methyltransferase 
from Clarkia breweri was engineered to catalyze the methylation of para-hydroxyl groups on monolignols, preventing them from $\beta-\mathrm{O}-4$ coupling with the free monomer. Introduction of the engineered enzyme into poplar resulted in an altered lignin content and structure, and improved biomass saccharification efficiency 346 . A similar approach would be to increase the content of tricin in lignins since it can only incorporate lignin via 4-O- $\beta$-coupling with a monolignol, and therefore, can only appear at the initiating end of the lignin chain (Figure 2). The recent discovery of tricin biosynthetic enzymes provides the prerequisite for such studies $350,351,352,353$. Biomass recalcitrance to degradation may be reduced by altering the lignin biosynthetic pathway to change the monomeric composition and linkage types of lignin ${ }^{354}$. This is the case for the aldehyde-rich lignin obtained via reduction of cinnamyl alcohol dehydrogenase activity 355,356 . Such lignins have a more hydrophobic surface that reduces its association with hemicelluloses ${ }^{357}$. Overexpression of ferulate 5-hydroxylase $(\mathrm{F} 5 \mathrm{H})$ leads to the formation of linear Slignin, in which monomers are attached with $\beta-O-4$ linkages, whereas downregulation of coumarate 3-hydroxylase $(\mathrm{C} 3 \mathrm{H})$ leads to the formation of $\mathrm{H}$-rich lignin. In both cases, biomass saccharification efficiency after ionic liquid pretreatment of these transgenic plants is enhanced compared to the control plants $^{358}$. Downregulation of caffeoyl-CoA O-methyltransferase (CCoAOMT) was shown to decrease the content of G monomers and to improve the efficiency of biomass enzymatic hydrolysis in alfalfa ${ }^{359}$. 
Lastly, identifying the transferase responsible for attaching acetate groups on lignin could represent a promising target for biomass engineering since a positive correlation between acetate content in biomass and saccharification efficiency was recently observed following certain biomass pretreatments in poplar ${ }^{360}$. Another approach to modify lignin structure is in planta degradation of $\beta$-aryl ether bonds through expression of bacterial lignin-degrading enzymes. In Arabidopsis, expression of the gene encoding the $\mathrm{C} \alpha$-dehydrogenase (LigD) from Sphingobium sp strain SYK-6 altered the lignin structure, which was reflected by an increased level of G-type $\alpha$-keto- $\beta-O-4$ linkages ${ }^{361}$. In a more extensive approach, coexpression of the genes encoding cell wall targeted LigD, LigF and LigG (Figure 14) resulted in the disruption of a detectable portion of the $\beta$-aryl ether bonds in lignin. The number of oxidized $G$ and $S$ units was increased but these units were no longer bound in $\alpha$-keto- $\beta-O-4$ linkages. This resulted in improved biomass saccharification efficiency ${ }^{362}$.

Figure 14. Pathway for degradation of $\beta$-O-4-linked units by Lig enzymes from Sphingobium paucimobilis exemplified with the model compound $\beta$ hydroxypropiovanillone ${ }^{363}$. GS, glutathione; GSSG, glutathione disulfide (oxidized GS).

The enzymes LigF and LigG are glutathione transferase enzymes (GSTs) (see Figure 14). GSTs of the plant specific lambda class (GSTLs) display in vitro activities orthogonal to that of LigG, namely the reductive cleavage of glutathione conjugates $^{364,365}$, as demonstrated recently in planta ${ }^{366}$. While no endogenous GST- 
mediated cleavage of lignin has yet been identified in planta, phenolic profiling in the studies of Mnich et al.362 indicated that a LigDFG-like pathway operates in wildtype Arabidopsis plants. Glutathione as well as GSTs (and other glutathione dependent enzymes) are present in the apoplast $367,368,369,370,371,372$. The possibility that an endogenous GST-mediated pathway for cleaving lignin crosslinks exists is intriguing but it remains to be investigated whether the hypothetical LigDFG-like pathway is apoplastic or, more likely, acts on intracellular substances such as lignans. Elucidation of this proposed pathway can open up new possibilities for engineering lignin structure, although the low apoplastic levels of glutathione may continue to be a bottleneck.

Recently, increased efforts have been made in exploring Lig enzymes from Sphingobium sp. SYK-6 $373,374,375,376$ and recently discovered, related enzymes from other bacteria ${ }^{377,378}$. These research initiatives aim to optimize the Lig enzyme systems for use in "Green chemistry", i.e. industrial scale in vitro-cleavage of lignin as a source of phenolics for the chemical industry as an alternative to the current production from fossil fuels. Use of Lig enzyme systems may also pave the way for the environmentally benign enzyme-based depolymerization of lignin in order to circumvent the current bottleneck in biofuel production. Several studies show that Lig enzymes tolerate extensive variation of side-chain structures for their substrates. This includes the ability to cleave both lignin- and non-lignin-type model substrates, and the ability to release many different monomers from softwood and hardwood lignins $373,377,378$. The released monomers included the high-value 
compound vanillin and ferulic acid373. The latter opens up the interesting possibility that Lig enzymes may also be able to cleave the lignin-ferulate or the ether 8-O-4 ferulate-ferulate crosslinks that are prevalent in grasses ${ }^{379,380}$. Identification of the hypothetical plant pathway for cleavage of $\alpha$-keto- $\beta-O-4$ linkages may also prove valuable to the green chemistry approach. For instance, such enzymes may prove to be highly stable in a strongly oxidizing environment if their natural habitat is found to be in the apoplast.

\section{Concluding remarks}

In this review, we have provided an overview of the phenolic cross-links that occur in plant cell walls. These structures, as well as the genes and enzymes responsible for their metabolism, have evolved to serve mainly structural purposes in the plants. We may see the structures as a source of inspiration for biomaterials or as impediments to the use of plant material for animal feed or biofuel. Our understanding of phenolic cross-links, their biological function, and how they are formed and cleaved is substantial, yet leaves us with a number of obvious shortcomings that future research should address:

- The precise biochemistry and subcellular localization of polysaccharide feruloylation remains to be elucidated.

- Interplay between plant peroxidases involved in extensin and lignin inter-unit linkages and the non-redundant roles of laccases and peroxidases in lignin polymerization have been demonstrated, but it remains to be discovered which peroxidases and/or laccases that catalyse GAX and lignan cross-linking. A 
comprehensive phylogenetic analysis of the peroxidase gene family resulting in consistent naming of clades across species would be conducive.

- Formation of intra-molecular vs. inter-molecular polysaccharide cross-links is difficult to predict and requires further studies in both Poacea and Caryophyllales.

- A realistic mechanism for the introduction of ether bond formation between sugars and phenyl propanoids may require the identification of a yet unrecognized type of enzyme.

- Elucidating the fine structure of cross-links between biopolymer families, extensin-RGI, extensin-lignin, lignin-mannan etc. is instrumental to the study of higher-order structures.

- Considering the importance of plant-microbe interactions in the environment and the impact of roots in shaping the rhizosphere, in-field evaluations of crops designed with modified lignin structure and/or phenolic cross-links should be prioritized.

A more thorough understanding of these issues would allow the plant breeder or the plant biotechnologist to more effectively breed for cell wall traits, which in turn will be conducive to developing cell wall deconstruction technologies.

\section{Acknowledgements}


We would like to thank the Innovation Foundation Denmark for funding (grant number 5152-00001B) to $\mathrm{PU}$ This work was part of the DOE Joint BioEnergy Institute (http://www.jbei.org) supported by the U. S. Department of Energy, Office of Science, Office of Biological and Environmental Research, through contract DE-AC02-05CH11231 between Lawrence Berkeley National Laboratory and the U.S. Department of Energy. 
${ }^{1}$ Serk, H., Gorzsas, A., Tuominen, H., Pesquet, E. Cooperative lignification of xylem tracheary elements. Plant Signal. Behav., 2015, 10: 4 doi: 10.1080/15592324.2014.1003753.

${ }^{2}$ Harris, P.J., Trethewey, J.A. The distribution of ester-linked ferulic acid in the cell walls of angiosperms. Phytochem. Rev., 2010, 9, 19-33.

${ }^{3}$ Sharova, E.I., Medvedev, S.S. Redox reactions in apoplast of growing cells. Russian Journal of Plant Physiol., 2017, 64, 1-14.

4 Francoz, E., Ranocha, P., Nguyen-Kim, H., Jamet, E., Burlat, V., Dunand, C. Roles of cell wall peroxidases in plant development. Phytochem. 2015 112, 15-21.

${ }^{5}$ Kärkönen, A., Kuchitsu, K. Reactive oxygen species in wall metabolism and development. Phytochem. 2015, 112, 22-32.

${ }^{6}$ Achyuthan, .KE., Achyuthan, A.M., Adams, P.D., Dirk, S.M., Harper, J.C., Simmons, B.A., Singh, A.K. Supramolecular self-assembled chaos: polyphenolic lignin's barrier to cost-effective lignocellulosic biofuels. Molecules, 2010, 15, 8641-8688.

${ }^{7}$ Köhler, L., Spatz, H-C. Micromechanics of plant tissues beyond the linear-elastic range. Planta 2002 215, 33-40.

8 Laschimke, R. Investigation of the wetting behaviour of natural lignin - a contribution to the cohesion theory of water transport in plants. Thermochimica Acta, 1989, 151, 35-56.

${ }^{9}$ Holbein, J., Franke, R.B., Marhavy, P., Fujita, S., Gorecka, M., Sobczak, M., Geldner, N., Schreiber, L., Grundler, F.M.W., Siddique, S. Root endodermal barrier system contributes to defence against plant-parasitic cyst and root-knot nematodes. Plant Journal, 2019, 100, 221-236 doi:

10.1111/tpj.14459

${ }^{10}$ Weng, J.K., Chapple, C. The origin and evolution of lignin biosynthesis. New Phytol., 2010, 187, 273-285.

${ }^{11}$ Voelker, S.L., Lachenbruch, B., Meinzer, F.C., Strauss, S.H. Reduced wood stiffness and strength, and altered stem form, in young antisense $4 \mathrm{CL}$ transgenic poplars with reduced lignin contents. New Phytol., 2011, 189, 1096-1109.

12 Ozparpucu, M., Ruggeberg, M., Gierlinger, N., Cesarino, I., Vanholme, R., Boerjan, W., Burgert, I. Unravelling the impact of lignin on cell wall mechanics: a comprehensive study on young poplar trees downregulated for CINNAMYL ALCOHOL DEHYDROGENASE (CAD). Plant J., 2017, 91, 480-490 doi: 10.1111/tpj.13584.

13 Davidson, J., Phillips, M. Lignin as a possible factor in lodging of cereals. Science, 1930, 72, 401402 doi: $10.1126 /$ science.72.1868.401.

${ }^{14}$ Peng, D.L., Chen, X.G., Yin, Y.P., Lu, K.L., Yang, W.B., Tang, Y.H., Wang, Z.L. Lodging resistance of winter wheat (Triticum aestivum L.): lignin accumulation and its related enzymes activities due to the application of paclobutrazol or gibberellin acid. Field Crops Res., 2014, 157, 1-7. 
${ }^{15}$ Beckers, B., Op De Beeck, M., Weyens, N., Van Acker, R., Van Montagu, M., Boerjan, W., Vangronsveld, J. Lignin engineering in field-grown poplar trees affects the endosphere bacterial microbiome. Proc. Natl. Acad. Sci. U S A., 2016, 113, 2312-2317

${ }^{16}$ Tilston, E.L,; Halpin, C., Hopkins, D.W. Simultaneous down-regulation of enzymes in the phenylpropanoid pathway of plants has aggregated effects on rhizosphere microbial communities. Biol. Fert. Soils., 2014, 50, 455-463.

17 Vassão, D.G., Kim, K.-W,. Davin, L.B., Lewis, N.G. Lignans (neolignans) and allyl/propenyl phenols: Biogenesis, structural biology, and biological/human health considerations. In:

Mander LN, Liu H-W (eds.) Comprehensive Natural Products // Chemistry and Biology, Elsevier, Oxford, UK, 2010, 815-928

18 Teponno, R.B., Kusari, S., Spiteller, M. Recent advances in research on lignans and neolignans Nat. Prod. Rep., 2016, 33, 1044-1092

19 Paniagua, C., Bilkova, A., Jackson, P., Dabravolski, S., Riber, W., Didi, V., Houser, J., GigliBisceglia, N., Wimmerova, M., Budínská, E., Hamann, T., Hejatko, J. Dirigent proteins in plants: modulating cell wall metabolism during abiotic and biotic stress exposure. J. Exp. Bot., 2017, 68, 3287-3301

${ }^{20}$ Bagniewska-Zadworna, A., Barakat, A., Lakomy, P., Smolinski, D.J., Zadworny, M. Lignin and lignans in plant defence: Insight from expression profiling of cinnamyl alcohol dehydrogenase genes during development and following fungal infection in Populus. Plant Sci., 2014, 229: 111-121 doi 10.1016/j.plantsci.2014.08.015

${ }^{21}$ Wang, Y., Chantreau, M., Sibout, R., Hawkins, S. Plant cell wall lignification and monolignol metabolism Front. Plant Sci., 2013, 4: 220 doi:10.3389/fpls.2013.00220

22 Dima, O., Morreel, K., Vanholme, B., Kim, H., Ralph, J., Boerjan, W. Small glycosylated lignin oligomers are stored in Arabidopsis leaf vacuoles. Plant Cell 2015, 27, 695-710.

${ }^{23}$ Ishii, T. Structure and functions of feruloylated polysaccharides. Plant Sci., 1997, 127, 111-127.

${ }^{24}$ Ralph, J., Quideau, S., Grabber, J.H., Hatfield R.D. Identification and synthesis of new ferulic acid dehydrodimers present in grass cell walls. J. Chem.I Soc., Perkin Transactions, 1994, 1, 3485-3498.

${ }^{25}$ Colquhoun, I.J., Ralet, M.-C., Thibault, J.-F., Faulds, C.B., Williamson, G. Structure identification of feruloylated oligosaccharides from sugar-beet pulp by NMR spectroscopy. Carb. Res., 1994, 263, 243-256.

${ }^{26}$ Wende, G., Fry S.C. 2-O- $\beta$-d-xylopyranosyl-(5-O-feruloyl)-I-arabinose, a widespread component of grass cell walls. Phytochem. 1997, 44, 1019-1030.

${ }^{27}$ Bunzel, M., Ralph, J., Steinhart, H. Phenolic compounds as cross-links of plant derived polysaccharides. Czech J. Food Sci., 2004, 22, 64-67.

${ }^{28}$ Boeriu, C.G., Oudgenoeg, G., Spekking, W.T.J., Berendsen, L.B., Vancon, L., Boumans, H., Gruppen, H. ; van Berkel, W.J., Laane, C., Voragen A.G. Horseradish peroxidase-catalyzed crosslinking of feruloylated arabinoxylans with $\beta$-casein. J. Agric. Food Chem., 2004, 52, 6633-6639. 
29 Oudgenoeg, G., Hilhorst, R. ; Piersma, S.R., Boeriu, C.G., Gruppen, H., Hessing, M., Voragen, A.G., Laane, C. Peroxidase-mediated cross-linking of a tyrosine-containing peptide with ferulic acid. J. Agric. Food Chem., 2001, 49, 2503-2510.

30 Van Sumere, C.,; De Pooter, H., Ali, H., Degrauw-van Bussel M. N-feruloylglycyl-I-phenylalanine: A sequence in barley proteins. Phytochem. 1973, 12, 407-411.

${ }^{31}$ Kamisaka, S., Takeda, S., Takahashi, K., Shibata K.. Diferulic and ferulic acid in the cell wall of Avena coleoptiles-Their relationships to mechanical properties of the cell wall. Physiol. Planarum, 1990, 78, 1-7

${ }^{32}$ MacAdam, J.W., Grabber J.H. Relationship of growth cessation with the formation of diferulate cross-links and p-coumaroylated lignins in tall fescue leaf blades. Planta 2002, 215, 785-793.

33 Tan, K.S., Hoson, T., Masuda, Y., Kamisaka S. Correlation between cell-wall extensibility and the content of diferulic and ferulic acids in cell-walls of Oryza sativa coleoptiles grown under water and in air. Physiol. Plantarum, 1991, 83, 397-403.

${ }^{34}$ Uddin, MN., Hanstein, S., Faust, F., Eitenmuller, P.T., Pitann, B., Schubert, S. Diferulic acids in the cell wall may contribute to the suppression of shoot growth in the first phase of salt stress in maize. Phytochem. 2014 102, 126-136.

${ }^{35}$ Bily, A., Reid, L. ; Taylor, J., Johnston, D., Malouin, C., Burt, A., Bakan, C., Regnault-Roger, C., Pauls, K., Arnason J. Dehydrodimers of ferulic acid in maize grain pericarp and aleurone: resistance factors to Fusarium graminearum. Phytopathol., 2003, 93, 712-719.

${ }^{36}$ Buanafina, M.D., Fescemyer, H. Modification of esterified cell wall phenolics increases vulnerability of tall fescue to herbivory by the fall armyworm. Planta 2012, 236, 513-523.

37 Santiago, R., Butrón, A., Reid, L.M., Arnason, .J.T., Sandoya, G., Souto, X.C., Malvar R.A. Diferulate content of maize sheaths is associated with resistance to the Mediterranean corn borer Sesamia nonagrioides (Lepidoptera: Noctuidae). J. Agric. Food Chem., 2006, 54, 9140-9144.

38 Waldron, K.W., Parr, A.J., Ng, A., Ralph, J. Cell Wall Esterified Phenolic Dimers: Identification and Quantification by Reverse Phase High Performance Liquid Chromatography and Diode Array Detection. Phytochem.I Anal., 1996, 7, 305-312.

${ }^{39}$ Showalter, AM., Keppler, B., Lichtenberg, J., Gu D, Welch, LR. A bioinformatics approach to the identification, classification, and analysis of hydroxyproline-rich glycoproteins. Plant Physiol., 2010, 153, 485-513.

40 Showalter, AM., Basu, D., Extensin and Arabinogalactan-Protein biosynthesis: Glycosyltransferases, Research Challenges, and Biosensors. Front. Plant Sci., 2016 7, 814

${ }^{41}$ Domingo, C., Sauri, A., Mansilla, E., Conejero, V., Vera, P. Identfication of a novel peptide motif that mediates cross-linking of proteins to cell walls. Plant J., 1999, 20, 563-570

42 Park, AR., Cho, SK., Yun, UJ., Jin, MY., Lee, SH,., Sachetto-Martins, G., Park, OK. Interaction of the arabidopsis receptor protein kinase Wak1 with a glycine-rich protein, AtGRP-3. J. Biol. Chem.,

2001, 276, 26688-26693 
${ }^{43}$ Kohorn, BD., Kobayashi, M., Johansen, S., Friedman, HP., Fischer, A., Byers, N. Wall-associated kinase 1 (WAK1) is crosslinked in endomembranes, and transport to the cell surface requires correct cell-wall synthesis. J. Cell Sci., 2006, 119, 2282-2290

${ }^{44}$ Tan, L., Eberhard, S., Pattathil, S., Warder, C., Glushka, J., Yuan, CH., Hao ,ZY., Zhu, X., Avci ,U., Miller, JS., Baldwin, D., Pham, C., Orlando, R., Darvill, A., Hahn, MG., Kieliszewski ,MJ., Mohnen, D. An Arabidopsis Cell Wall Proteoglycan Consists of Pectin and Arabinoxylan Covalently Linked to an Arabinogalactan Protein. Plant Cell, 2013, 25, 270-287.

${ }^{45}$ Cannon, M.C., Terneus, K., Hall Q., Tan, L., Wang, Y., Wegenhart, B.L., Chen, L., Lamport, D.T.A., Chen, Y., Kieliszewski, M.J. Self-assembly of the plant cell wall requires an extensin scaffold. Proc. Natl. Acad. Sci. USA., 2008, 105, 2226-2231.

46 Lamport, D.T.A., Kieliszewski, M.J., Chen, Y., Cannon, M.C. Role of the Extensin Superfamily in Primary Cell Wall Architecture. Plant Physiol., 2011 156, 11-19.

47 Draeger, C., Ndinyanka Fabrice, T., Gineau, E., Mouille, G., Kuhn, B.M., Moller, I., Abdou, M-T., Frey, B., Pauly, M., Bacic, A., Ringli, C. Arabidopsis leucine-rich repeat extensin (LRX) proteins modify cell wall composition and influence plant growth. BMC Plant Biology, 2015, 15, 155

${ }^{48}$ Borassi, C., Sede, A.R., Mecchia, M.A., Salter J.D.S., Marzol, M., Muschietti, J.P., Estevez J.M. An update on cell surface proteins containing extensin-motifs. J. Exp. Bot., 2016, 67,477-487

49 Wang, X.X., Wang, K.Y., Yin, G.M., Liu, X.Y., Liu, M., Cao, N.N., Duan, Y.Z., Gao, H., Wang, W.L., Ge, W.N., Wang, J., Li, R., Guo, Y. Pollen-Expressed Leucine-Rich Repeat Extensins Are Essential for Pollen Germination and Growth. Plant Physiol., 2018, 176, 1993-2006

50 Francoz, E., Ranocha, P., Nguyen-Kim, H., Jamet, E., Burlat, V., Dunand, C. Roles of cell wall peroxidases in plant development. Phytochem. 2015, 112, 15-21.

${ }^{51}$ Ringli, C. The hydroxyproline-rich glycoprotein domain of the Arabidopsis LRX1 requires Tyr for function but not for insolubilization in the cell wall. Plant J., 2010, 63, 662-669.

52 Grabber, JH., Ralph, J., Hatfield, RD. Cross-linking of maize walls by ferulate dimerization and incorporation into lignin. J. Agric. Food Chem. 2000, 48, 6106-6113.

${ }^{53}$ Moore, T. S.. An extracellular macromolecular complex from the surface of soybean suspension cultures, Plant Physiol., 1973, 51, 529-536

54 Whitmore, F. W.. Lignin-protein complex in cell walls of Pinus elliottii: Amino acid constituents," Phytochemistry, 1982 21, 315-318.

${ }^{55}$ Cong, F., Diehl, B. G., Hill, J. L., Brown, N. R., and Tien, M. Covalent bond formation between amino acids and lignin: Cross-coupling between proteins and lignin. Phytochemistry, 2013, 96, 449456

56 Lange, B. M., Lapierre, C., and Sandermann, H. (Elicitor-induced spruce stress lignin: Structural similarity to early developmental lignins. Plant Physiol., 1995, 108, 1277-1287

${ }^{57}$ Fleming, M.B., Decker, S.R., Bedinger, P.A. Investigating the Role of Extensin Proteins in Poplar Biomass Recalcitrance. BioResources, 2016, 11, 4727-4744 
${ }^{58}$ Fan, C., Li, Y., Hu, Z., Hu, H., Wang, G., Li, A., Wang, Y., Tu, Y., Xia, T., Peng, L., Feng, S. Ectopic expression of a novel OsExtensin-like gene consistently enhances plant lodging resistance by regulating cell elongation and cell wall thickening in rice. Plant Biotechnology Journal, 2018, 16, 254-263

${ }^{59}$ Mazau, D., Esquerretugaye, M.T. Hydroxyproline-Rich Glycoprotein Accumulation in the CellWalls of Plants Infected by Various Pathogens. Physiol. Mol. Plant Pathol., 1986, 29, 147-157.

60 Mazau, D., Esquerretugaye, M.Y. Hydroxyproline (Hyp) and Peroxidases in Cell-Wall and Cytoplasm of Melon Plants Infected with Anthracnose Fungus. Plant Sci. Lett., 1976, 7, 119-125.

${ }^{61}$ Deepak, S., Shailasree, S., Kini, R.K., Muck, A., Mithofer, A., Shetty, S.H. Hydroxyproline-rich Glycoproteins and Plant Defence. J. Phytopathol. 2010, 158, 585-593

62 Reem, N.T., Pogorelko, G., Lionetti, V., Chambers, L., Held, MA., Bellincampi, D., Zabotina, O.A. Decreased Polysaccharide Feruloylation Compromises Plant Cell Wall Integrity and Increases Susceptibility to Necrotrophic Fungal Pathogens. Front. Plant Sci., 2016, 7, 630. doi: 10.3389/fpls.2016.00630.

63 Boerjan, W., Ralph, J., Baucher, M. Lignin biosynthesis. Annu. Rev. Plant Biol. 2003, 54, 519-546 ${ }^{64}$ Rinaldi, R., Jastrzebski, R., Clough, M.T., Ralph, J., Kennema, M., Bruijnincx, PC., Weckhuysen, B.M. Paving the Way for Lignin Valorisation: Recent Advances in Bioengineering, Biorefining and Catalysis. Angew. Chem. Int. Ed. Engl., 2016, 55, 8164-8215.

65 Anderson, E.M., Stone, M.L., Katahira, R., Reed, M., Muchero, W., Ramirez, K.J., Beckham, G.T., Roman-Leshkov, Y. Differences in S/G ratio in natural poplar variants do not predict catalytic depolymerization monomer yields. Nature Communications, 2019, 10, 2033 doi: 10.1038/s41467019-09986-1

${ }^{66}$ Belyi, V.A., Karmanov, A.P., Kocheva, L.S. 2D NMR Spectroscopic Study of Lignin from Triticum sp. and Larix sibirica. Chemistry of Natural Compounds, 2015, 51, 929-933 doi: 10.1007/s10600015-1450-1

67 Stewart, J.J., Akiyama, T., Chapple, C., Ralph, J., Mansfield, S.D. The effects on lignin structure of overexpression of ferulate 5-hydroxylase in hybrid poplar. Plant Physiol. 2009, 150, 621-635. doi: 10.1104/pp.109.137059

${ }^{68}$ Quideau, S., and Ralph, J. Lignin-ferulate cross-links in grasses. Part 4. Incorporation of 5-5coupled diferulate into lignin. J. Chem. Soc., Perkin Trans., 1997, 1, 2351-2358.

69 Lan, W., Lu, F., Regner, M., Zhu, Y., Rencoret, J., Ralph, SA., Zakai, U.I., Morreel, K., Boerjan, W., Ralph, J. Tricin, a flavonoid monomer in monocot lignification. Plant Physiol., 2015, 167:1284-1295

70 Lan, W., Rencoret, J., Lu, F., Karlen, SD., Smith, BG., Harris, PJ., et al. Tricin-Lignins: occurrence and quantitation of tricin in relation to phylogeny. Plant J., 2016, 88, 1046-1057.

${ }^{71}$ Ralph, J., Kim, H., Peng, J., Lu, F. Arylpropane-1,3-diols in lignins from normal and CAD-deficient pines. Org. Lett., 1999, 1, 323-326.

${ }^{72}$ Chen, F., Tobimatsu, Y., Havkin-Frenkel, D., Dixon, R.A., Ralph J. A polymer of caffeyl alcohol in plant seeds. Proc. Natl. Acad. Sci. USA., 2012, 109,1772-1777. 
${ }^{73}$ Chen, F., Tobimatsu, Y., Jackson, L., Nakashima, J., Ralph, J., Dixon, R.A. Novel seed coat lignins in the Cactaceae: structure, distribution and implications for the evolution of lignin diversity. Plant J., 2012, 73, 201-211.

${ }^{74}$ Adler, E., Ellmer, L. Coniferylaldehydgruppen in Holz und in isolierten Ligninpraparaten. Acta Chem. Scand., 1948, 2, 839-840.

75 del Río J, Rencoret J, Gutiérrez A, Kim H, Ralph J. Hydroxystilbenes Are Monomers in Palm Fruit Endocarp Lignins. Plant Physiol., 2017, 174,2072-2082.

76 del Rio, J.C., Rencoret, J., Marques, G., Gutierrez, A., Ibarra, D., Santos, J.I., Jimenez-Barbero, J., Zhang, L.M., Martinez, A.T. Highly Acylated (Acetylated and/or p-Coumaroylated) Native Lignins from Diverse Herbaceous Plants. J. Agric. Food Chem., 2008, 56, 9525-9534

77 Lu, F., Karlen, SD., Regner, M., Kim, H., Ralph, SA., Sun, R., Kuroda, K., Augustin, M.A., Mawson, R., Sabarez, H., Singh, T, Jimenez-Monteon, G., Zakaria, S., Hill, S., Harris, P., Boerjan, W., Wilkerson C., Mansfield, S., Ralph, J. Naturally p-hydroxybenzoylated lignins in palms. BioEnergy Res., 2015, 8, 934-952.

${ }^{78}$ Smith, D.C.C. p-Hydroxybenzoate groups in the lignin of aspen (Populus tremula). J. Chem. Soc. 1955, 0, 2347-2351.

79 Karlen, S.D., Smith, R.A., Kim, H., Padmakshan, D., Bartuce, A., Mobley, J.K., Free, H.C.A., Smith, B.G., Harris, P.J., Ralph, J. Highly Decorated Lignins in Leaf Tissues of the Canary Island Date Palm Phoenix canariensis. Plant Physiol., 2017, 175, 1058-1067

80 Kim H., Ralph, J., Lu, F.C., Ralph, S.A., Boudet, A.M., MacKay, J.J., Sederoff, R.R., Ito, T., Kawai, S., Ohashi, H., Higuchi, T. NMR analysis of lignins in CAD-deficient plants. Part 1. Incorporation of hydroxycinnamaldehydes and hydroxybenzaldehydes into lignins. Org. Biomol. Chem., 2003, 1,268-281.

${ }^{81}$ Ralph, J., Hatfield, RD., Piquemal, J, ., Yahiaoui, N., Pean, M., Lapierre, C., Boudet, A.M. NMR characterization of altered lignins extracted from tobacco plants down-regulated for lignification enzymes cinnamylalcohol dehydrogenase and cinnamoyl-CoA reductase. Proc. Natl. Acad. Sci. USA., 1998, 95,12803-12808.

82 Lam, PY., Tobimatsu, Y., Takeda, Y., Suzuki, S., Yamamura, M ., Umezawa, T., Lo, C. Disrupting Flavone Synthase II Alters Lignin and Improves Biomass Digestibility. Plant Physiol., 2017, 174, $972-$ 985

${ }^{83}$ Grabber, J.H., Ress, D., Ralph, J. Identifying new lignin bioengineering targets: impact of epicatechin, quercetin glycoside, and gallate derivatives on the lignification and fermentation of maize cell walls. J. Agric. Food. Chem., 2012, 60, 5152-60.

${ }^{84}$ Tobimatsu, Y., Elumalai, S., Grabber, J.H., Davidson, C.L., Pan, X., Ralph, J. Hydroxycinnamate conjugates as potential monolignol replacements: in vitro lignification and cell wall studies with rosmarinic acid. ChemSusChem., 2012, 5, 676-86.

85 Davin, L.B., Jourdes, M., Patten, A.M., Kim, K.W., Vassao, D.G., Lewis, N.G. Dissection of lignin macromolecular configuration and assembly: Comparison to related biochemical processes in allyl/propenyl phenol and lignan biosynthesis. NPR, 2008, 25, 1015-1090 
86 Patten, A.M., Jourdes, M., Cardenas, C.L., Laskar, D.D., Nakazawa, Y., Chung, B.Y., Franceschi, V.R., Davin, L.B., Lewis, N.G. Probing native lignin macromolecular configuration in Arabidopsis thaliana in specific cell wall types: Further insights into limited substrate degeneracy and assembly of the lignins of ref8, fah 1-2 and C4H::F5H lines. Molecular Biosystems, 2010, 6, 499-515 doi: $10.1039 / \mathrm{b} 819206 \mathrm{e}$

87 Moinuddin, S.G.A., Jourdes, M., Laskar, D.D., Ki, C., Cardenas, C.L., Kim, K.W., Zhang, D., Davin, L.B., Lewis, N.G. Insights into lignin primary structure and deconstruction from Arabidopsis thaliana COMT (caffeic acid O-methyl transferase) mutant Atomt1. Organic \& Biomolecular Chemistry, 2010, 8, 3928-3946 doi: 10.1039/c004817h

${ }^{88}$ Talmadge, K.W., Keegstra, K., Bauer, W.D., Albersheim, P. Structure of Plant-Cell Walls .1. Macromolecular Components of Walls of Suspension-Cultured Sycamore Cells with a Detailed Analysis of Pectic Polysaccharides. Plant Physiol., 1973, 51, 158-173.

89 McNeil, M., Darvill, A.G., Albersheim, P. Structure of Plant-Cell Walls .10. Rhamnogalacturonan-I, a Structurally Complex Pectic Polysaccharide in the Walls of Suspension-Cultured Sycamore Cells. Plant Physiol., 1980, 66, 1128-1134.

90 Harholt, J., Jensen, J.K., Verhertbruggen, Y., Sogaard, C., Bernard, S; Nafisi, M., Poulsen, C.P., Geshi, N., Sakuragi, Y., Driouich, A., Knox, J.P., Scheller, H.V. ARAD proteins associated with pectic Arabinan biosynthesis form complexes when transiently overexpressed in planta. Planta 2012, 236, 115-128.

${ }^{91}$ Liwanag, A.J.M., Ebert, B., Verhertbruggen, Y., Rennie, E.A., Rautengarten, C., Oikawa, A., Andersen, M.C.F., Clausen, M.H., Scheller, H.V. Pectin Biosynthesis: GALS1 in Arabidopsis thaliana Is a beta-14-Galactan beta-14-Galactosyltransferase. Plant Cell, 2012, 24, 5024-5036.

92 Uehara, Y., Tamura, S., Maki, Y., Yagyu, K., Mizoguchi, T., Tamiaki, H., Imai, T., Ishii, T ., Ohashi, T., Fujiyama, K., Ishimizu, T., Biochemical characterization of rhamnosyltransferase involved in biosynthesis of pectic rhamnogalacturonan I in plant cell wall. Biochem. Biophys. Res. Comm., 2017, 486, 130-136.

93 Takenaka, Y., Kato, K., Mari Ogawa-Ohnishi, Tsuruhama, K., Kajiura, H., Yagyu, K., Takeda, A., Takeda, Y., Kunieda, T., Hara-Nishimura, I., Kuroha, T., Nishitani, K., Matsubayashi, Y., Ishimizu, T. Pectin RG-I rhamnosyltransferases represent a novel plant-specific glycosyltransferase family. Nature Plants, 2018, 4, 669-676

94 Macquet, A., Ralet, M.C., Loudet, O., Kronenberger, J., Mouille, G., Marion-Poll, A., North, H.M. A naturally occurring mutation in an Arabidopsis accession affects a beta-D-galactosidase that increases the hydrophilic potential of rhamnogalacturonan I in seed mucilage. Plant Cell, 2007, 19: 3990-4006.

95 Dean, G.H., Zheng, H.Q., Tewari, J., Huang, J., Young, D.S., Hwang, Y.T., Western, T.L., Carpita, N.C., McCann, M.C., Mansfield, S.D., Haughn, .G The Arabidopsis MUM2 gene encodes a betagalactosidase required for the production of seed coat mucilage with correct hydration properties. Plant Cell, 2007, 19, 4007-4021. 
96 Makshakova, O.N., Gorshkova, T.A., Mikshina, P.V., Zuev, Y.F., Perez, S. Metrics of rhamnogalacturonan I with beta-(1 -> 4)-galactan side chains and structural basis for its selfaggregation. Carb. Polym., 2017, 158, 93-101.

${ }^{97}$ Rombouts, FM., Thibault, J.F. Sugar-Beet Pectins - Chemical-Structure and Gelation Through Oxidative Coupling. ACS Symposium Series, 1986, 310, 49-60.

98 Levigne, S.V., Ralet, M.C.J., Quemener, B.C., Pollet, B.N.L., Lapierre, C., Thibault, J.F.J. Isolation from sugar beet cell walls of Arabinan oligosaccharides esterified by two ferulic acid monomers. Plant Physiol., 2004, 134, 1173-1180.

99 Ishii, T., Tobita, T. Structural Characterization of Feruloyl Oligosaccharides from Spinach-Leaf Cell-Walls. Carb. Res., 1993, 248, 179-190.

100 Nuñex, A., Fishman ,M.L., Fortis, L.L., Cooke, P., Hotchkiss, A.T. Jr. Identification of Extensin Protein Associated with Sugar Beet Pectin. J Agric Food Chem. 2009, 57, 10951-109518

101 Qi, X., Behrens, B.X., West, P.R., Mort, A.J. Solubilization and Partial Characterization of Extensin Fragments from Cell Walls of Cotton Suspension Cultures. Plant Physiol., 1995, 108, 1691-1701

102 Ebringerova, A., Heinze, T. Xylan and xylan derivatives - biopolymers with valuable properties, 1 - Naturally occurring xylans structures, procedures and properties. Macromol. Rapid Comm. 2000, 21, 542-556.

${ }^{103}$ Darvill, JE., McNeil, M., Darvill, AG., Albersheim, P. Structure of Plant-Cell Walls .11. Glucuronoarabinoxylan, A 2nd Hemicellulose in the Primary-Cell Walls of Suspension-Cultured Sycamore Cells. Plant Physiol., 1980 66, 1135-1139.

104 Schröder, R., Brummell D.A. Xylan metabolism in primary cell walls. New Zeal. J. For. Sci. 2009, 39, 125-143.

105 Appeldoorn, M.M., de, Waard, P., Kabel, M.A., Gruppen, H., Schols, H.A. Enzyme resistant feruloylated xylooligomer analogues from thermochemically treated corn fiber contain large side chains, ethyl glycosides and novel sites of acetylation. Carb. Res. 2015, 381, 33-42.

106 Chateigner-Boutin, AL., Ordaz-Ortiz, JJ., Alvarado, C., Bouchet, B., Durand, S., Verhertbruggen, Y., Barriere, Y., Saulnier, L. Developing Pericarp of Maize: A Model to Study Arabinoxylan Synthesis and Feruloylation. Frontiers in Plant Science 2016, 7, 1476, doi: 10.3389/fpls.2016.01476.

107 Smith, M.M., Hartley, R.D. Occurrence and nature of ferulic acid substitution of cell-wall polysaccharides in graminaceous plants. Phytochem. 1983, 118, 65-80.

108 Boz, H. Ferulic acid in cereals - a review. Czech J. Food Sci. 2015, 33, 1-7.

109 Huisman, M. M., Schols, H., Voragen, A. G. Glucuronoarabinoxylans from maize kernel cell walls are more complex than those from sorghum kernel cell walls. Carb. Polym. 2000, 43, 269-279.

${ }^{110}$ Appeldoorn, M.M., Kabel, M.A., Van Eylen, D., Gruppen, H., Schols, H.A. Characterization of Oligomeric Xylan Structures from Corn Fiber Resistant to Pretreatment and Simultaneous Saccharification and Fermentation. J. Agric. Food Chem. 2010, 58, 11294-11301.

111 Selig, M. J., Adney, W. S., Himmel, M. E., Decker, S. R. The impact of cell wall acetylation on corn stover hydrolysis by cellulolytic and xylanolytic enzymes. Cellulose 2009, 16, 711-722. 
112 Biely, P). Microbial carbohydrate esterases deacetylating plant polysaccharides. Biotechnol. Adv., 2012, 30, 1575-1588.

113 Chanliaud, E., Saulnier, L., Thibault, J.-F. Alkaline extraction and characterisation of heteroxylans from maize bran. J. Cereal Sci., 1995, 21, 195-203,

${ }^{114}$ Chanliaud, E., Roger, P., Saulnier, L., Thibault, J.-F. Static and dynamic light scattering studies of heteroxylans from maize bran in aqueous solution. Carb. Polym., 1996, 31, 41-46.

115 Saulnier, L., Marot, C., Chanliaud, E., Thibault, J.F. Cell wall polysaccharide interactions in maize bran. Carb. Polym. 1995, 26, 279-287.

116 Knudsen, K.E.B. Carbohydrate and lignin contents of plant materials used in animal feeding. Anim. Feed Sci. Tech., 1997, 67, 319-338..

117 Yang, J., Maldonado-Gómez, M. X., Hutkins, R. W., Rose, D. J. Production and in Vitro fermentation of soluble, non-digestible, feruloylated oligo- and polysaccharides from maize and wheat brans. J. Agric. Food Chem., 2014, 62, 159-166.

118 Rose, D. J., Inglett, G. E. A Method for the Determination of Soluble Arabinoxylan Released from Insoluble Substrates by Xylanases, Food Ana. Meth., 2011, 4, 66-72

119 Biely, P. Microbial Glucuronoyl Esterases: 10 Years after Discovery. Appl. Environ. Microbiol., 2016, 82, 7014-7018.

120 Hartley, R.D., and C.W. Ford. Phenolic constituents of plant cell walls and wall biodegradability. Plant cell wall polymers, biogenesis and biodegradation, 1989, 399, 137-145.

${ }^{121}$ Bunzel, M., Ralph, J., Lu, F., Hatfield, R. D., Steinhart, H. Lignins and ferulate-coniferyl alcohol cross-coupling products in cereal grains. J. Agric. Food Chem., 2004, 52, 6496-6502.

122 Burr, SJ., Fry, S.C. Feruloylated Arabinoxylans Are Oxidatively Cross-Linked by Extracellular Maize Peroxidase but Not by Horseradish Peroxidase. Mol. Plant, 2009, 2, 883-892.

$123 \mathrm{Du}, \mathrm{X}$., Gellerstedt, G., Li, J. Universal fractionation of lignin-carbohydrate complexes (LCCs) from lignocellulosic biomass: an example using spruce wood. Plant J, 2013, 74, 328-338

124 Oinonen, P., Zhang, L.M., Lawoko, M., Henriksson, G. On the formation of lignin polysaccharide networks in Norway spruce. Phytochem. 2015, 11, 177-184.

125 Nishimura, H., Kamiya, A., Nagata, T., Katahira, M., Watanabe, T. Direct evidence for $\alpha$ ether linkage between lignin and carbohydrates in wood cell walls. Sci. Rep., 2018, 8, 6538.

${ }^{126}$ Mottiar, Y., Vanholme, R., Boerjan, W., Ralph, J, Mansfield, S.D. Designer lignins: harnessing the plasticity of lignification. Curr. Opin. Biotechnol., 2016, 37, 190-200.

${ }^{127}$ Agger, J., Viks $\varnothing$-Nielsen, A., Meyer, A. S.. Enzymatic xylose release from pretreated corn bran arabinoxylan: differential effects of deacetylation and deferuloylation on insoluble and soluble substrate fractions. J. Agric. Food Chem., 2010, 58, 6141-6148.

${ }^{128}$ Bunzel, M., Ralph, J., Brüning, P., Steinhart H. Structural identification of dehydrotriferulic and dehydrotetraferulic acids isolated from insoluble maize bran fiber. J. Agric. Food Chem., 2006, 54, 6409-6418. 
${ }^{129}$ Schendel, R. R., Meyer, M. R., Bunzel, M. Quantitative Profiling of Feruloylated Arabinoxylan Side-Chains from Graminaceous Cell Walls. Front. Plant Sci., 2016, 6, 1249.

130 Vaidyanathan, S., Bunzel, M., Development and Application of a Methodology to Determine Free Ferulic Acid and Ferulic Acid Ester-Linked to Different Types of Carbohydrates in Cereal Products. Cereal Chem., 2012, 89, 247-254.

131 Pedersen, M. B., Bunzel, M., Schäfer, J., Knudsen, K. E. B., Sørensen, J.F., Yu, S., Lærke, H. N. Ferulic Acid Dehydrodimer and Dehydrotrimer Profiles of Distiller's Dried Grains with Solubles from Different Cereal Species. J. Agric. Food Chem., 2015, 63, 2006-2012.

132 Dobberstein, D., Bunzel, M. Separation and detection of cell wall-bound ferulic acid dehydrodimers and dehydrotrimers in cereals and other plant materials by reversed phase highperformance liquid chromatography with ultraviolet detection. J. Agric. Food Chem., 2010, 58, 8927-8935.

133 Grabber, J.H., Hatfield, R.D., Ralph, J. Diferulate cross-links impede the enzymatic degradation of non-lignified maize walls. J. Sci. Food Agric., 1998 77, 193-200.

134 Grabber, J.H., Ralph, J., Hatfield R.D. Ferulate cross-links limit the enzymatic degradation of synthetically lignified primary walls of maize. J. Agric. Food Chem., 1998 46, 2609-2614.

135 Piber, M., Koehler, P. Identification of dehydroferulic acidtyrosine in rye and wheat: Evidence for a covalent cross-link between arabinoxylans and proteins. J. Agric. Food Chem., 2005 53, 52765284.

136 Kerr, E.M., Fry S.C. Extracellular cross-linking of xylan and xyloglucan in maize suspension cultures: the role of oxidative phenolic coupling, Planta 2004, 219, 73-83.

137 Pereira, C.S., Silveira, R. L., Dupree, P., Skaf, M.S. Effects of Xylan Side-Chain Substitutions on Xylan-Cellulose Interactions and Implications for Thermal Pretreatment of Cellulosic Biomass, Biomacromol., 2017, 18, 1311-1321.

138 Simmons, T.J., Mortimer, J.C., Bernardinelli, O.D., Poppler, A.C., Brown, S.P., Deazevedo, E.R., Dupree, R., Dupree, P. Folding of xylan onto cellulose fibrils in plant cell walls revealed by solidstate NMR. Nature Comm., 2016, 7, 13902. doi:10.1038/ncomms13902.

139 Nieduszynski, I., Marchessault, R.H. Structure of beta-D- (1-->4') xylan hydrate. Nature, 1971, 232, 46-47.

140 Wang ,T., Hong, M. Solid-state NMR investigations of cellulose structure and interactions with matrix polysaccharides in plant primary cell walls. J. Exp. Bot., 2016, 67, 503-514.

141 Wang, T., Park, Y.B,.., Cosgrove, D.J., Hong, M. Cellulose-Pectin Spatial Contacts Are Inherent to Never-Dried Arabidopsis Primary Cell Walls: Evidence from Solid-State Nuclear Magnetic Resonance. Plant Physiol., 2015, 16I, 871-884.

142 Rennie, E. A., and Scheller, H. V. Xylan biosynthesis. Curr. Opin. Biotechnol., 2014, 26, 100-107.

${ }^{143}$ Appeldoorn, M.M., de Waard, P., Kabel, M.A., Gruppen, H., Schols, H.A. Enzyme resistant feruloylated xylooligomer analogues from thermochemically treated corn fiber contain large side chains, ethyl glycosides and novel sites of acetylation. Phytochem. 2015, 381, 33-42. 
144 Yoshida-Shimokawa, T., Yoshida, S., Kakegawa, K., Ishii T. Enzymic feruloylation of arabinoxylantrisaccharide by feruloyl-CoA: arabinoxylan-trisaccharide O-hydroxycinnamoyl transferase from Oryza sativa. Planta 2001, 212, 470-474.

145 Obel, N., Porchia, A., Scheller H. Intracellular feruloylation of arabinoxylan in wheat: evidence for feruloyl-glucose as precursor. Planta 2003, 216, 620-629.

146 Bokern, M., Wray, V., Strack D. Accumulation of phenolic acid conjugates and betacyanins, and changes in the activities of enzymes involved in feruloylglucose metabolism in cell-suspension cultures of Chenopodium rubrum L. Planta 1991, 184, 261-270.

147 Hu, W.-J., Harding, S.A. ; Lung, J., Popko, J.L ., Ralph, J., Stokke, D.D., Tsai, C.-J., Chiang, V.L.. Repression of lignin biosynthesis promotes cellulose accumulation and growth in transgenic trees. Nature biotechnol., 1999, 17, 808-812.

148 Buanafina, M., Cosgrove, D., Fincher, G., Höfte H. Feruloylation in grasses: current and future perspectives. Mol. Plant, 2009, 2, 861-872.

${ }^{149}$ Fry, S.Intracellular feruloylation of pectic polysaccharides. Planta 1987, 171, 205-211

150 Myton, K.E., Fry S.C. Intraprotoplasmic feruloylation of arabinoxylans in Festuca arundinacea cell cultures. Planta 1994, 193, 326-330.

151 Mastrangelo, L., Lenucci, M., Piro, G., Dalessandro G. Evidence for intra- and extra-protoplasmic feruloylation and cross-linking in wheat seedling roots. Planta 2009, 229,343-355.

152 Mitchell, R.A., Dupree, P., Shewry P.R. A novel bioinformatics approach identifies candidate genes for the synthesis and feruloylation of arabinoxylan. Plant physiol., 2007, 144, 43-53.

153 D'Auria JC. Acyltransferases in plants: a good time to be BAHD. Curr. Opin. Plant Biol., 2006, 9, 331-340.

154 Yang, Q., Reinhard, K., Schiltz, E., Matern, U. Characterization and heterologous expression of hydroxycinnamoyl/benzoyl-CoA: anthranilate N-hydroxycinnamoyl/benzoyltransferase from elicited cell cultures of carnation, Dianthus caryophyllus L. Plant Mol. Biol., 1997, 35, 777-789.

155 Carpita, N.C. Structure and biogenesis of the cell walls of grasses. Ann. Rev. Plant Biol., 1996, 47, 445-476.

156 Piston, F., Uauy, C., Fu, L., Langston, J., Labavitch, J., Dubcovsky J. Down-regulation of four putative arabinoxylan feruloyl transferase genes from family PF02458 reduces ester-linked ferulate content in rice cell walls. Planta 2010, 231, 677-691.

157 Buanafina, M.M., Fescemyer, H.W., Sharma, M., Shearer, E.A. Functional testing of a PF02458 homologue of putative rice arabinoxylan feruloyl transferase genes in Brachypodium distachyon. Planta 2016, 243, 659-674.

158 de Souza, W.R., Martins, P.K., Freeman, J., Pellny, T.K., Michaelson, L.V., Sampaio, B.L., Vinecky, F., Ribeiro, A.P., da Cunha, B.A.D.B., Kobayashi, A.K., de Oliveira, P.A., Campanha. R.B., Pacheco, T.F., Martarello, D.C.I., Marchiosi, R., Ferrarese-Filho, O., Dos Santos, W.D., Tramontina, R., Squina, F.M., Centeno, D.C., Gaspar, M., Braga, M.R., Tiné, M.A.S., Ralph, J., Mitchell, R.A.C., Molinari, 
H.B.C. Suppression of a single BAHD gene in Setaria viridis causes large, stable decreases in cell wall feruloylation and increases biomass digestibility. New Phytol., 2018, 218, 81-93.

159 Bartley, L.E., Peck, M.L., Kim, S.R., Ebert, B., Manisseri, C., Chiniquy, D.M., Sykes, R., Gao, L.F., Rautengarten, C., Vega-Sanchez, M.E., Benke, P.I., Canlas, P.E., Cao, P.J., Brewer, S., Lin, F., Smith, W.L., Zhang, X.H., Keasling, J.D., Jentoff, R.E., Foster, S.B., Zhou, J.Z., Ziebell, A., An, G., Scheller, H.V., Ronald, P.C. Overexpression of a BAHD Acyltransferase, OsAt10, Alters Rice Cell Wall Hydroxycinnamic Acid Content and Saccharification. Plant Physiol., 2013, 161, 1615-1633 doi: 10.1104/pp.112.208694

160 Li, G., Jones, K., Eudes, A., Pidatala, V., Sun, J., Xu, F., Zhang, C., Wei, T., Jain, R., Birdseye, D., Canlas, P., Baidoo, E., Duong, P., Sharma, M., Singh, S., Ruan, D., Keasling, J., Mortimer, J., Loqué D., Bartley, L., Scheller, H., Ronald, P. Overexpression of a rice BAHD acyltransferase gene in switchgrass (Panicum virgatum L.) enhances saccharification. BMC Biotech, 2018, 18, 54

${ }^{161}$ Chiniquy, D., Sharma, V., Schultink, A., Baidoo, E.E., Rautengarten, C., Cheng, K., Carroll, A., Ulvskov, P., Harholt, J., Keasling J.D. XAX1 from glycosyltransferase family 61 mediates xylosyltransfer to rice xylan. Proc. Natl. Acad. Sci. USA., 2012 109:17117-17122.

162 Konishi, T., Takeda, T., Miyazaki, Y., Ohnishi-Kameyama, M., Hayashi, T., O'Neill, M.A., Ishii T. A plant mutase that interconverts UDP-arabinofuranose and UDP-arabinopyranose. Glycobiology, 2007 17, 345-354.

163 Dhugga, K.S., Tiwari, S.C., Ray P.M. A reversibly glycosylated polypeptide (RGP1) possibly involved in plant cell wall synthesis: purification, gene cloning, and trans-Golgi localization. Proc. Natl, Acad. Sci. USA, 1997 94, 7679-7684.

164 Petrik, D.L., Karlen, S.D., Cass, C.L., Padmakshan, D., Lu, F., Liu, S., Bris, P., Antelme, S., Santoro, N., Wilkerson C.G. P-Coumaroyl-CoA: monolignol transferase (PMT) acts specifically in the lignin biosynthetic pathway in Brachypodium distachyon. Plant J., 2014 77, 713-726.

165 Serra, O., Hohn, C., Franke, R., Prat, S., Molinas, M., Figueras M. A feruloyl transferase involved in the biosynthesis of suberin and suberin-associated wax is required for maturation and sealing properties of potato periderm. Plant J. 2010 62, 277-290.

166 Rautengarten, C., Ebert, B., Ouellet, M., Nafisi, M., Baidoo, E.E, Benke, P., Stranne, M., Mukhopadhyay, A., Keasling, J.D., Sakuragi, Y., Scheller, H.V. Arabidopsis Deficient in Cutin Ferulate encodes a transferase required for feruloylation of $\omega$-hydroxy fatty acids in cutin polyester. Plant Physiol., 2012, 158, 654-665

167 Ralph, J. Hydroxycinnamates in lignification. Phytochem. Rev., 2010 9, 65-83.

168 Bunzel, M., Ralph, J., Kim, H., Lu, F., Ralph, S.A., Marita, J.M., Hatfield, R.D., Steinhart, H. Sinapate dehydrodimers and sinapate-ferulate heterodimers in cereal dietary fiber. J. Agric. Food Chem. 2003 51, 1427-1434.

${ }^{169}$ Ralph, J., Lundquist, K., Brunow, G., Lu, F., Kim, H., Schatz, P.F., Marita, J.M ., Hatfield, R.D., Ralph, S.A., Christensen, JH., Boerjan, W. Lignins: natural polymers from oxidative coupling of 4hydroxyphenylpropanoids. Phytochem. Rev., 2010, 3, 29-60.

170 Chen, Y.N., Dong, W., Tan, L., Held, M.A., Kieliszewski, M.J. Arabinosylation Plays a Crucial Role in Extensin Cross-linking In Vitro. Biochemistry Insights, 2015, 8, 1-13. 
171 Lamport, D.T.A., Miller, D.H. Hydroxyproline arabinosides in the plant kingdom. Plant Physiol. $1971,48,454-456$

172 Guo, X., Hansen, B.Ø., Moeller, S.R., Harholt, J., Mravec, J., Willats, W., Petersen, B.L., Ulvskov, P. Extensin arabinoside chain length is modulated in elongating cotton fibre. The Cell Surface, 2019, 100033 doi: 10.1016/j.tcsw.2019.100033

173 Carreras, A., Driouich, A., Plancot, B., Boulogne, I., Ropitaux, M., Follet-Gueye, M.-L., Castilleux, R., Vicré, M., Leprince, J., Popper, Z.A. Cell wall extensins in root-microbe interactions and root secretions. J. Exp. Bot., 2018, 69, 4235-4247

${ }^{174}$ Domozych, D.S., Marina, Ciancia, M., Fangel, J.U., Mikkelsen, M.D., Ulvskov, P., Willats, W.G.T. The Cell Walls of Green Algae: A Journey through Evolution and Diversity. Front Plant Sci., 2012 3, 82, doi: 10.3389/fpls.2012.00082.

175 Kieliszewski, M., Lamport, D.T.A., Tam, L., Cannon, M.C. Hydroxyproline-rich glycoproteins: form and function. In: Plant Polysaccharides, biosynthesis and bioengineering (P. Ulvskov ed.). Ann. Plant Reviews, 2011 41, 321-342. Blackwell.

176 Tiainen, P., Myllyharju, J., Koivunen, P. Characterization of a second Arabidopsis thaliana prolyl 4-hydroxylase with distinct substrate specificity. J. Biol. Chem., 2005, 280, 1142-1148.

177 Velasquez, S.M., Ricardi, M.M., Dorosz, J.G., Fernandez, P.V., Nadra, A.D., Pol-Fachin, L., Egelund, J., Gille, S., Harholt, J., Ciancia, M., Verli, H., Pauly, M., Bacic, A, ., Olsen, C.E., Ulvskov, P., Petersen, B.L., Somerville, C., lusem, N.D., Estevez, J.M. (2011) O-Glycosylated Cell Wall Proteins Are Essential in Root Hair Growth. Science, 2011 332, 1401-1403.

178 Velasquez, S.M., Ricardi, M.M., Poulsen, CP., Oikawa, A., Dilokpimol, A., Halim, A., Mangano, S., Denita Juarez, S.P., Marzol, E., Salgado Salter, J.D., Dorosz, J.G., Borassi, C., Möller, S.R., Buono, R., Ohsawa Y., Matsuoka, K., Otegui, M.S., Scheller, H.V., Geshi, N., Petersen, BmL., lusem, N.D., Estevez, J.M. Complex regulation of prolyl-4-hydroxylases impacts root hair expansion. Mol. Plant, 2015 8, 734-746.

179 Ferris, P.J., Woessner, J.P., Waffenschmidt, S, ., Kilz, S., Drees, J., Goodenough, U.W. Glycosylated polyproline II rods with kinks as a structural motif in plant hydroxyproline-rich glycoproteins. Biochemistry, 2001 40, 2978-2987.

180 Epstein, I., Lamport, D.T.A. An intramolecular linkage involving isodityrosine in extensin. Phytochem. 1984 23, 1241-1246.

${ }^{181}$ Brady, J.D., Saddler, I.H., Fry, S.C. Di-isodityrosine, a novel tetrameric derivative of tyrosine in plant cell wall proteins: a new potential cross-link. Biochem. J., 1996 315, 323-327.

182 Brady, J.D., Saddler, I.H., Fry, S.C. Pulcherosine, an oxidatively coupled trimer of tyrosine in plant cell walls: Its role in cross-link formation. Phytochem. 1998 47, 349-353.

${ }^{183}$ Cannon, M.C., Terneus, K., Hall, Q., Tan, L., Wang, Y., Wegenhart, B.L., Chen, L., Lamport, D.T., Chen, Y., Kieliszewski, M.J. Self-assembly of the plant cell wall requires an extensin scaffold. Proc. Natl. Acad. Sci. USA., 2008 105, 2226-2231. 
${ }^{184}$ Saha P., Ray T., Tang Y., Dutta I., Evangelous N.R., Kieliszewski M.J., Chen Y., Cannon M.C. Selfrescue of an EXTENSIN mutant reveals alternative gene expression programs and candidate proteins for new cell wall assembly in Arabidopsis. Plant J., 2013 75, 104-116.

185 Hall, Q., Cannon, M.C. The cell wall hydroxyproline-rich glycoprotein RSH is essential for normal embryo development in Arabidopsis. Plant Cell 2002, 14, 1161-1172.

186 Saito, F., Suyama, A., Oka, T, ., Yoko, OT., Matsuoka, K., Jigami, Y., Shimma, Y.I. Identification of Novel Peptidyl Serine alpha-Galactosyltransferase Gene Family in Plants. J. Biol. Chem., 2014 289, 20405-20420.

187 Ogawa-Ohnishi, M., Matsushita, W., Matsubayashi, Y. Identification of three hydroxyproline Oarabinosyltransferases in Arabidopsis thaliana. Nat. Chem. Biol., 2013 9 726-730.

188 MacAlister, C.A., Ortiz-Ramirez, C., Becker, J.D., Feijo, J.A., Lippman, Z.B. Hydroxyproline Oarabinosyltransferase mutants oppositely alter tip growth in Arabidopsis thaliana and Physcomitrella patens. Plant J., 2016 85, 193-208.

189 Egelund, J., Obel, N., Ulvskov, P., Geshi, N., Pauly, M., Bacic, A., Petersen B.L. Molecular characterization of two Arabidopsis thaliana glycosyltransferase mutants, rra1 and rra2, which have a reduced residual arabinose content in a polymer tightly associated with the cellulosic wall residue. Plant Mol. Biol., 2007 64, 439-451.

190 Gille, S., Hansel, U., Ziemann, M., Pauly, M. Identification of plant cell wall mutants by means of a forward chemical genetic approach using hydrolases. Proc. Natl. Acad. Sci. U S A, 2009 106, 14699-14704.

191 Møller, S.R., Yi, X., Velásquez, S.M., Gille, S., Hansen, P.M.L., Poulsen, C.P., Olsen, CE., Rejzek, M., Parsons, H., Zhang, Y., Wandall, H.H., Clausen, H., Field, R.A., Pauly, M., Estevez, J.M., Harholt, J., Ulvskov, P., Petersen, B.L. Identification and evolution of a plant cell wall specific glycoprotein glycosyl transferase, ExAD. Nat. Sci. Rep., 2017 7, 45341. doi: 10.1038/srep45341.

192 Hatfield, R.D., Rancour, D.M., Marita, J.M. Grass Cell Walls: A Story of Cross-Linking. Front. Plant Sci., 2017 7, 2056 doi: 10.3389/fpls.2016.02056.

193 Zikeli, F., Ters, T., Fackler, K., Srebotnik, E., Li J. Fractionation of wheat straw Dioxane lignin reveals molar mass dependent structural differences. Industrial Crops and Products, 2016, 91, 186193.

194 Jacquet, G., Pollet, B., Lapierre, C., Mhamdi, F., Rolando, C. New ether-linked ferulic acidconiferyl alcohol dimers identified in grass straws. J. Agric. Food Chem., 1995 43, 2746-2751.

195 Grabber, J.H., Ralph, J., Hatfield R.D. Model studies of ferulate-coniferyl alcohol cross-product formation in primary maize walls: Implications for lignification in grasses. J. Agric. Food Chem., $200250,6008-6016$.

196 Jung, H.-J.G. Maize stem tissues: ferulate deposition in developing internode cell walls. Phytochem. 2003 63, 543-549.

197 Allerdings, E., Ralph, J., Steinhart, H., Bunzel M. Isolation and structural identification of complex feruloylated heteroxylan side-chains from maize bran. Phytochem. 2006 67, 1276-1286. 
198 Grabber, J.H., Ralph, J., Lapierre, C., Barrière Y. Genetic and molecular basis of grass cell-wall degradability. I. Lignin-cell wall matrix interactions. Comptes rendus biologies, 2004 327, 455-465. 199 Hatfield, R., Ralph, J., Grabber J. A potential role for sinapyl p-coumarate as a radical transfer mechanism in grass lignin formation. Planta 2008 228, 919-928.

200 Lan, W., Morreel, K., Lu, F., Rencoret, J., Carlos Del Río, J., Voorend, W., Vermerris, W., Boerjan, W., Ralph, J. Maize Tricin-Oligolignol Metabolites and Their Implications for Monocot Lignification. Plant Physiol., 2016 171, 810-820.

${ }^{201}$ Ralph, J., Grabber, J.H., Hatfield R.D. Lignin-ferulate cross-links in grasses: active incorporation of ferulate polysaccharide esters into ryegrass lignins. Phytochem. 1995 275, 167-178.

202 Passardi, F., Penel, C,., Dunand, C. Performing the paradoxical: how plant peroxidases modify the cell wall. Trends Plant Sci., 2004 9, 534-540.

${ }^{203}$ Fagerstedt, K., Kukkola, E., Koistinen, V.V.T., Takahashi, J., Marjamaa, K. Cell wall lignin is polymerized by class III secretable plant peroxidase in Norway spruce. J. Integr. Plant Biol., 2010 52, 186-194.

204 Wallace, G., Fry, S.C. Action of diverse peroxidases and laccases on six cell wall-related phenolic compounds Phytochem. 1999 52, 769-773.

205 Munk, L., Sitarz, A.K., Kalyani, D.C., Mikkelsen, J.D., Meyer, A.S. Can laccases catalyze bond cleavage in lignin? Biotechnology Advances, 2015 33, 13-24.

206 Turlapati, P.V., Kim, K.W., Davin, L.B., Lewis, N.G. The laccase multigene family in Arabidopsis thaliana: towards addressing the mystery of their gene function(s). Planta 2011 233, 439-470.

207 Valério, L., De Meyer, M., Penel, C., Dunand, C. Expression analysis of the Arabidopsis peroxidase multigenic family. Phytochem. 2004 65, 1331-1342.

208 Vogel JP., Garvin DF., Mockler TC., Schmutz J., Rokhsar D., Bevan MW, ., et al. Genome sequencing and analysis of the model grass Brachypodium distachyon. Nature, 2010 463, 763-768.

209 Passardi, F., Longet, D., Penel, C., Dunand, C. The class III peroxidase multigenic family in rice and its evolution in land plants. Phytochem. 2004 65, 1879-1893.

210 Moural, T.W., Lewis, K.M., Barnaba, C., Zhu, F., Palmer, N.A., Sarath, G., Scully, E.D., Jones, J.P., Sattler, S.E., Kang, C. Characterization of Class III Peroxidases from Switchgrass. Plant Physiol., 2017 173, 417-433.

${ }^{211}$ Shigeto, J., Itoh, Y., Hirao, S., Ohira, K., Fujita, K., Tsutsumi, Y. Simultaneously disrupting AtPrx2, AtPrx25 and AtPrx71 alters lignin content and structure in Arabidopsis stem. J. Integr. Plant Biol., 2015 57, 349-356.

212 Cosio, C., Ranocha, P., Francoz, E., Burlat, V., Zheng, Y., Perry, S.E., Ripoll, J.J., Yanofsky, M., Dunand C. The class III peroxidase PRX17 is a direct target of the MADS-box transcription factor AGAMOUS-LIKE15 (AGL15) and participates in lignified tissue formation. New Phytol., 2017 213, 250-263. 
${ }^{213}$ Fernández-Pérez, F., Pomar, F., Pedreño, M.A., Novo-Uzal, E. The suppression of AtPrx52 affects fibers but not xylem lignification in Arabidopsis by altering the proportion of syringyl units. Physiol. Plant., 2015, 154, 395-406.

214 Lee, Y., Rubio, M.C., Alassimone, J., Geldner, N. 2013. A mechanism for localized lignin deposition in the endodermis. Cell, 2013 153, 402-412.

215 Shigeto, J., Kiyonaga, Y., Fujita, K., Kondo, R., Tsutsumi, Y. Putative cationic cell-wall-bound peroxidase homologues in Arabidopsis, AtPrx2, AtPrx25, and AtPrx71, are involved in lignification. J. Agric. Food Chem., 201361 3781-3788.

${ }^{216}$ Blee, K.A., Choi, J.W., O'Connell, A.P., Schuch, W ., Lewis, NG., Bolwell, G.P. A lignin-specific peroxidase in tobacco whose antisense suppression leads to vascular tissue modification.

Phytochem. 2003 64, 163-176.

217 Lin, C.-Y., Li, Q., Tunlaya-Anukit, S., Shi, R., Sun, Y.-H., Wang, J.P., Liu, J., Loziuk, P., Edmunds, C.W., Miller, Z.D., Peszlen, I., Muddiman, D.C., Sederoff, R.R., Chiang, V.L. A cell wall-bound anionic peroxidase, PtrPO21, is involved in lignin polymerization in Populus trichocarpa.. Tree Genet. Genomes, 2016 12, 22 doi.org/10.1007/s11295-016-0978-y.

${ }^{218} \mathrm{Li}$, Y., Kajita, S., Kawai, S., Katayama, Y., Morohoshi, N. Down-regulation of an anionic peroxidase in transgenic aspen and its effect on lignin characteristics. J. Plant Res., 2003 116, 175782 .

219 Mansouri, I.E., Mercado, J.A., Santiago-Dómenech, N., Pliego-Alfaro, F., Valpuesta, V., Quesada, M.A. Biochemical and phenotypical characterization of transgenic tomato plants overexpressing a basic peroxidase. Physiol. Plantarum, 1999 106, 355-352.

220 Wang, Y., Bouchabke-Coussa, O., Lebris, P., Antelme, S., Soulhat, C., Gineau, E, ., Dalmais, M., Bendahmane, A., Morin, H., Mouille, G., Legee, F., Cezard, L., Lapierr,e C., Sibout, R. LACCASE5 Is Required for Lignification of the Brachypodium distachyon Culm. Plant Physiol., 2015 168, 192204.

221 Bryan, A.C., Jawdy, S., Gunter, L., Gjersing, E., Sykes, R., Hinchee, M.A., Winkeler, K.A., Collins, C.M., Engle, N., Tschaplinski, T.J., Yang, X., Tuskan, G.A., Muchero, W., Chen, J.G. Knockdown of a laccase in Populus deltoides confers altered cell wall chemistry and increased sugar release. Plant Biotechnol J., 2016 14, 2010-2020.

222 Berthet, S., Demont-Caulet, N., Pollet, B., Bidzinski, P., Cézard, L., Le Bris, P., Borrega, N., Hervé, J., Blondet, E., Balzergue, S., Lapierre, C., Jouanin, L. Disruption of LACCASE4 and 17 results in tissue-specific alterations to lignification of Arabidopsis thaliana stems. Plant Cell, 2011 23, 11241137.

223 Zhao, Q ., Nakashima, J., Chen, F., Yin, Y.B., Fu, C.X., Yun, J.F., Shao, H., Wang, X.Q., Wang, Z.Y., Dixon, R.A. LACCASE Is Necessary and Nonredundant with PEROXIDASE for Lignin Polymerization during Vascular Development in Arabidopsis. Plant Cell, 2013 25, 3976-3987.

${ }^{224}$ Liang, M., Davis, E., Gardner, D., Cai, X., Wu, Y. Involvement of AtLAC15 in lignin synthesis in seeds and in root elongation of Arabidopsis. Planta 2006 224, 1185-9116. 
225 Hu, Q.,, Min, L., Yang, X., Jin, S., Zhang, L., Li, Y., Ma, Y., Qi, X., Li, D., Liu, H., Lindsey, K., Zhu, L., Zhang, $X$. Laccase GhLac1 modulates broad-spectrum biotic stress tolerance via DAMP-triggered immunity. Plant Physiol., 2017 doi: 10.1104/pp.17.01628.

${ }^{226}$ Lu, S., Li, Q., Wei, H., Chang, M.J., Tunlaya-Anukit, S., Kim, H., Liu, J., Song, J., Sun, Y.H., Yuan, L., Yeh, T.F., Peszlen, I, ., Ralph, J., Sederoff, R.R., Chiang, V.L. Ptr-miR397a is a negative regulator of laccase genes affecting lignin content in Populus trichocarpa. Proc. Natl. Acad. Sci. USA., 2013 110, 10848-10853.

${ }^{227}$ Cesarino, I., Araújo, P., Sampaio Mayer, J.L., Vicentini, R., Berthet, S., Demedts, B., Vanholme, B., Boerjan, W., Mazzafera, P. Expression of SofLAC, a new laccase in sugarcane, restores lignin content but not S:G ratio of Arabidopsis lac17 mutant. J Exp Bot., 2013 64, 1769-1781.

228 Fawal, N., Li, Q., Savelli, B., Brette, M., Passaia, G., Fabre, M., Mathé, C., Dunand, D. PeroxiBase: a database for large-scale evolutionary analysis of peroxidases. Nucleic Acids Res., 2013 41(Database issue), D441-4. PMID:23180785.

229 Duroux, L., Welinder, K.G. The peroxidase gene family in plants: a phylogenetic overview. J. Mol. Evol., 2003 57, 397-407.

${ }^{230}$ Fernández-Pérez, F., Vivar, T., Pomar, F ., Pedreño, M.A., Novo-Uzal, E. Peroxidase 4 is involved in syringyl lignin formation in Arabidopsis thaliana. J. Plant Physiol., 2015 175, 86-94.

${ }^{231}$ Herrero, J., Fernández-Pérez, F., Yebra, T., Novo-Uzal, E., Pomar, F., Pedreño, M.Á., Cuello, J., Guéra, A., Esteban-Carrasco, A., Zapata, J.M. Bioinformatic and functional characterization of the basic peroxidase 72 from Arabidopsis thaliana involved in lignin biosynthesis. Planta 2013 237, 1599-612.

232 Schuetz, M., Benske, A., Smith, R.A., Watanabe, Y., Tobimatsu, Y., Ralph, J., Demura, T., Ellis, B., Samuels, A.L. Laccases Direct Lignification in the Discrete Secondary Cell Wall Domains of Protoxylem. Plant Physiol., 2014 166, 798-807.

${ }^{233}$ Wang, P., Calvo-Polanco, M., Reyt, G., Barberon, M., Champeyroux, C., Santoni, V., Maurel, C., Franke, R.B., Ljung, K., Novak, O., Geldner, N., Boursiac, Y., Salt, D.E. Surveillance of cell wall diffusion barrier integrity modulates water and solute transport in plants. Scientific Reports, 2019, 9, 4227 doi: $10.1038 /$ s41598-019-40588-5

${ }^{234}$ Sun, Q., Liu, X., Yang, J., Liu, W., Du, Q., Wang, H., Fu, C., Li, W.X. MicroRNA528 affects lodging resistance of maize by regulating lignin biosynthesis under nitrogen-luxury conditions. Mol Plant., 2018, 11, 806-814.

235 Davin, L.B., Wang, H.B., Crowell, A.L., Bedgar, D.L., Martin, D.M., Sarkanen S., Lewis N.G, Stereoselective bimolecular phenoxy radical coupling by an auxiliary (dirigent) protein without an active center. Science, 1997, 275: 362-366 doi: 10.1126/science.275.5298.36

236 Sartorelli P., Benevides P.J.C., Ellensohn R.M., Rocha M.V.A.F., Moreno P.R.H., Kato M.J. Enantioselective conversion of $\mathrm{p}$-hydroxypropenylbenzene to (+)-conocarpan in Piper regnellii Plant Science, 2001, 161, 1083-1088

237 Withers, S., Lu, F., Kim, H., Zhu, Y., Ralph, J. and Wilkerson, C.G. Identification of grass-specific enzyme that acylates monolignols with p-coumarate. J. Biol. Chem., 2012 287, 8347-8355. 
238 Marita, J.M., Hatfield, R.D., Rancour, D.M., Frost, K.E. Identification and suppression of the pcoumaroyl CoA:hydroxycinnamyl alcohol transferase in Zea mays L. Plant J., 2014 78, 850-864.

${ }^{239}$ Eudes, A., Mouille, M., Robinson, D.S., Benites, V.T., Wang, G., Roux, L., Tsai, Y.L., Baidoo, E.E., Chiu ,T.Y., Heazlewood, J.L., Scheller, H.V., Mukhopadhyay, A., Keasling, J.D., Deutsch, S., Loqué, D. Exploiting members of the BAHD acyltransferase family to synthesize multiple hydroxycinnamate and benzoate conjugates in yeast. Microb. Cell Fact., 2016 15, 198, doi: 10.1186/s12934-016-05935 .

${ }^{240}$ Eudes A., Teixeira Benites V., Wang G., Baidoo E.E., Lee T.S., Keasling J.D., Loqué D. PrecursorDirected Combinatorial Biosynthesis of Cinnamoyl, Dihydrocinnamoyl, and Benzoyl Anthranilates in Saccharomyces cerevisiae. PLoS One., 2015 10, e0138972.

${ }^{241}$ Chedgy, R.J., Köllner, T.G., Constabel, C.P. Functional characterization of two acyltransferases from Populus trichocarpa capable of synthesizing benzyl benzoate and salicyl benzoate, potential intermediates in salicinoid phenolic glycoside biosynthesis. Phytochem. 2015 113, 149-159.

242 Bontpart T., Cheynier V., Ageorges A., Terrier N. BAHD or SCPL acyltransferase? What a dilemma for acylation in the world of plant phenolic compounds. New Phytol., 2015, 208, 695-707.

243 Dexter, R., Qualley, A., Kish, C.M., Ma, C.J, ., Koeduka, T., Nagegowda, D.A., Dudareva, N., Pichersky, E., Clark, D. Characterization of a petunia acetyltransferase involved in the biosynthesis of the floral volatile isoeugenol. Plant J., 2007, 49, 265-275.

244 Koeduka, T., Suzuki, S., lijima, Y., Ohnishi, T., Suzuki, H., Watanabe, B., Shibata, D.,Umezawa, T., Pichersky, E., Hiratake, J. Enhancement of production of eugenol and its glycosides in transgenic aspen plants via genetic engineering. Biochem. Biophys. Res. Commun., 2013, 436, 73-78.

245 Lu, D., Yuan, X., Kim, S.J., Marques, J.V., Chakravarthy, P.P., Moinuddin, S.G.A., Luchterhand, R., Herman, B., Davin, L.B., Lewis, N.G. Eugenol specialty chemical production in transgenic poplar (Populus tremula $\times$ P. alba) field trials. Plant Biotechnol. J., 2017, 15, 970-981.

246 Wilkerson, C., Mansfield, S., Lu, F., Withers, S., Park, J.-Y., Karlen, S., Gonzales-Vigil, E., Padmakshan, D., Unda, F., Rencoret J;. Monolignol Ferulate Transferase Introduces Chemically Labile Linkages into the Lignin Backbone. Science, 2014, 344, 90-93.

${ }^{247}$ Karlen, S.D., Zhang, C., Peck, M.L., Smith, R.A., Padmakshan, D., Helmich, K.E., Free, H.C., Lee, S., Smith, B.G., Lu, F., Sedbrook, J.C., Sibout, R,., Grabber, J.H., Runge, T.M., Mysore, K.S., Harris, PJ., Bartley, L.E., Ralph J. Monolignol ferulate conjugates are naturally incorporated into plant lignins. Sci. Adv., 2016, 2, e1600393.

${ }^{248}$ Smith, R.A., Gonzales-Vigil, E., Karlen, S.D., Park, J.Y., Lu F., Wilkerson, C.G., Samuels, L., Ralph, J., Mansfield, S.D. Engineering Monolignol p-Coumarate Conjugates into Poplar and Arabidopsis Lignins. Plant Physiol., 2015, 169, 2992-3001.

${ }^{249}$ Sibout, R., Le Bris, P., Legee, F., Cezard, L., Renault, H., Lapierre, C. Structural Redesigning Arabidopsis Lignins into Alkali-Soluble Lignins through the Expression of $p$-Coumaroyl-CoA: Monolignol Transferase PMT. Plant Physiol. 2016, 170, 1358-1366 
250 Davin, L.B., Wang, H.B., Crowell, A.L., Bedgar, D.L., Martin, D.M., Sarkanen, S., Lewis, N.G. Stereoselective bimolecular phenoxy radical coupling by an auxiliary (dirigent) protein without an active center. Science, 1997, 275, 362-366.

251 Pickel, B., Constantin, M.A., Pfannstiel, J., Conrad, J., Beifuss, U., Schaller, A. An enantiocomplementary dirigent protein for the enantioselective laccase-catalyzed oxidative coupling of phenols. Angew Chem. Int. Ed. Engl., 2010, 49, 202-204.

252 Gang, D.R., Costa, M.A., Fujita, M., Dinkova-Kostova, A.T., Wang, H.B., Burlat, V., Martin, W., Sarkanen, S., Davin, L.B., Lewis, N.G. Regiochemical control of monolignol radical coupling: a new paradigm for lignin and lignan biosynthesis. Chem. Biol., 1999, 6, 143-151.

253 Burlat, V., Kwon, M., Davin, L.B., Lewis, N.G. Dirigent proteins and dirigent sites in lignifying tissues. Phytochem. 2001, 57, 883-897.

${ }^{254}$ Shi, H., Liu, Z., Zhu, L., Zhang, C., Chen, Y., Zhou, Y., Li, F., Li, X. Overexpression of cotton (Gossypium hirsutum) dirigent1 gene enhances lignification that blocks the spread of Verticillium dahliae. Acta Biochim. Biophys. Sin. (Shanghai), 2012, 44, 555-564.

255 Ruprecht, C., Mutwil, M., Saxe, F., Eder, M., Nikoloski, Z., Persson, S. Large-scale co-expression approach to dissect secondary cell wall formation across plant species. Front. Plant Sci., 2011, 2, 23

256 Niculaes, C., Morreel, K., Kim, H., Lu, F., McKee, L.S., Ivens, B., Haustraete, J., Vanholme, B., Rycke, R.D., Hertzberg, M., Fromm, J., Bulone, V., Polle, A., Ralph, J., Boerjan, W. Phenylcoumaran benzylic ether reductase prevents accumulation of compounds formed under oxidative conditions in poplar xylem. Plant Cell, 2014, 26, 3775-3791.

257 Hosmani, P.S., Kamiya, T., Danku, J., Naseer, S., Geldner, N., Guerinot, M.L., Salt, D.E. Dirigent domain-containing protein is part of the machinery required for formation of the lignin-based Casparian strip in the root. Proc. Natl. Acad. Sci. USA., 2013, 110, 4498-14503.

258 Held, M.A., Tan, L., Kamyab, A., Hare, M., Shpak, E., Kieliszewski, M.J. Di-isodityrosine Is the Intermolecular Cross-link of Isodityrosine-rich Extensin Analogs Cross-linked in Vitro. J. Biol Chem., 2004, 279, 55474-55482.

${ }^{259}$ Cegelski, L., O’Connor, R.D., Stueber, D., Singh, M., Poliks, B., Schaefer, J. Plant Cell-Wall Cross-Links by REDOR NMR Spectroscopy. J. Am. Chem. Soc. 2010, 132, 16052-16057

260 Jackson, P.A., Galinha, C.I., Pereira, C.S., Fortunato, A., Soares, N.C., Amancio, S.B., Pinto Ricardo, C.P. Rapid deposition of extensin during the elicitation of grapevine callus cultures is specifically catalyzed by a 40-kilodalton peroxidase. Plant Physiol., 2004, 127, 1065-1076.

261 Pereira, C.S., Ribeiro, J.M., Vatulescu, A.D., Findlay, K., MacDougall, A.J., Jackson, P.A. Extensin network formation in Vitis vinifera callus cells is an essential and causal event in rapid and $\mathrm{H}_{2} \mathrm{O}_{2}$ induced reduction in primary cell wall hydration. BMC Plant Biol., 2011, 11, 106 doi: 10.1186/1471-2229-11-106.

262 Dong, W., Kieliszewski, M., Held, M.A. Identification of the pl 4.6 extensin peroxidase from Lycopersicon esculentum using proteomics and reverse-genomics. Phytochem. 2015, 112, 151-159. 
${ }^{263}$ Price, N.J., Pinheiro, C., Soares, C.M., Ashford, D.A., Ricardo, C.P., Jackson, P.A. A biochemical and molecular characterization of LEP1, an extensin peroxidase from lupin. J. Biol. Chem., 2003, 278, 41389-41399 .

264 Blee, K.A., Jupe, S.C., Richard, G., Zimmerlin, A., Davies, D.R., Bolwell, G.P. Molecular identification and expression of the peroxidase responsible for the oxidative burst in French bean (Phaseolus vulgaris L.) and related members of the gene family. Plant Mol. Biol., 2001, 47, 607620.

${ }^{265}$ Rashid, A. Defense responses of plant cell wall non-catalytic proteins against Pathogens. Physiol. Mol. Plant Pathol., 2016, 94: 38-46.

${ }^{266}$ Fukao, Y., Ferjani, A., Fujiwara, M., Nishimori, Y., Ohtsu, I. Identification of Zinc-Responsive Proteins in the Roots of Arabidopsis thaliana Using a Highly Improved Method of Two-Dimensional Electrophoresis. Plant and Cell Physiol., 2009, 50, 2234-2239.

267 Ju, S., Go, Y.S., Choi, H.J., Park, J.M., Suh, M.C. DEWAX Transcription Factor Is Involved in Resistance to Botrytis cinerea in Arabidopsis thaliana and Camelina sativa. Front. Plant Sci., 2017, 8, 1210 doi: 10.3389/fpls.2017.01210.

268 Wakabayashi, K., Soga, K., Hoson, T. Phenylalanine ammonia-lyase and cell wall peroxidase are cooperatively involved in the extensive formation of ferulate network in cell walls of developing rice shoots. J. Plant Physiol., 2012, 169, 262-267.

${ }^{269}$ Callister, W.D. Materials Science and Engineering. 3rd ed. New York John Wiley \& Sons INC. 1994, 514-515.

270 Ion, S., Opris, C., Cojocaru, B., Tudorache, M., Zgura, I., Galca, A.C., Bodescu, A.M., Enache, M., Maria, G.M., Parvulescu, V.I. One-pot enzymatic production of lignin-composites. Front. Chem., 2018, 6, doi: 10.3389/fchem.2018.00124.

271 Greimel, K.J., Kudanga, T., Nousiainen, P., Sipilä, J., Acero, E.H., Nyanhongo, G.S., Guebitz, G.M. Two distinct enzymatic approaches for coupling fatty acids onto lignocellulosic materials. Process Biochem., 2017, 59, 111-115.

272 Wu, H., Silva, C., Yu, Y., Dong, A., Wang, Q., Fan, X., Wang, P., Yuan, J., Cavaco-Paulo, A. Hydrophobic functionalization of jute fabrics by enzymatic-assisted grafting of vinyl copolymers. New J. Chem., 2017, 41, 3773-3780.

273 Pei, J., Zhang, Y., Zhang, F., Yu, X., Yan, X. Enhancing antimicrobial activity in unbleached kraft pulp using laccase and phenolic compounds. BioResources, 2013, 8, 515-529

${ }^{274}$ Liu, M., Baum, A., Odermatt, J., Berger, J., Yu, L., Zeuner, B., Thygesen, A., Holck, J., Meyer, A.S. Oxidation of lignin in hemp fibers by laccase: effects on mechanical properties of hemp fibers and unidirectional fiber/epoxy composites. Composites Part A: Applied Science and Manufacturing, 2016, 95, 377-387.

275 Álvarez, C., Rojano, B., Almaza, O., Rojas, O.J., Gañán, P. Self-bonding boards from plantain fiber bundles after enzymatic treatment: adhesion improvement of lignocellulosic products by enzymatic pre-treatment. J. Polym. Environ., 2011, 19, 182-188. 
${ }^{276}$ Batog, J., Kozlowski, R., and, Przepiera, A. Lignocellulosic composites bonded by enzymatic oxidation of lignin. Mol. Cryst. Liq. Cryst., 2008, 484, 35/[401]-42/[408] Doi:

$10.1080 / 15421400801903387$.

277 Dong, A., Li, F., Fan, X., Wang, Q., Yu, Y., Wang, P., Yuan, J., Cavaco-Paulo, A. Enzymatic modification of jute fabrics for enhancing the reinforcement in jute/PP composites. Mol. Cryst. Liq. Cryst., 2018, 31, 483-499.

278 Elegir, G., Bussini, D., Antonsson, S., Lindström, M.E., Zoia, L. Laccase-initiated cross-linking of lignocellulose fibres using an ultra-filtered lignin isolated from kraft black liquor. J. Polym. Environ. Appl. Microbiol. Biot., 2007, 77, 809-817.

279 Nasir, M., Gupta, A., Hossen, Beg, M.D., Chua, G.K., Asim, M. Laccase application in medium density fibreboard to prepare a bio-composite. RSC Advances, 2014, I, 11520-11527.

280 Ni, X., Dong, A., Fan, X., Wang, Q., Yu, Y., Cavaco-Paulo, A. Jute/polypropylene composites: effect of enzymatic modification on thermo-mechanical and dynamic mechanical properties. Fibers and Polymers, 2015, 16, 2276-2283.

${ }^{281}$ Kharazipour, A., Bergmann, K., Nonninger, K., Huttermann, A. Properties of fibre boards obtained by activation of the middle lamella lignin of wood fibres with peroxidase and $\mathrm{H}_{2} \mathrm{O}_{2}$ before conventional pressing. J. Adhes. Sci. Technol., 1998, 12, 1045-1053.

282 Oinonen, P., Krawczyk, H., Ek, M., Henriksson, G., Moriana, R. Bioinspired composites from cross-linked galactoglucomannan and microfibrillated cellulose: thermal, mechanical and oxygen barrier properties. Carb. Polym., 2016, 136, 146-153.

283 Paës, G., Burr, S., Saab, M.B., Molinari, M., Aguié-Béghin, V., Chabbert, B. Modeling progression of fluorescent probes in bioinspired lignocellulosic assemblies. Biomacromol., 2013, 14, 21962205.

284 Paës, G., Schantz, L.V., Ohlin, M. Bioinspired assemblies of plant cell wall polymers unravel the affinity properties of carbohydrate-binding modules. Soft Matter, 2015, 11, 6586-6594.

285 Garcia-Ubasart, J., Colom, J.F., Vila, C., Gomez, Hernandez, N., Blanca, Roncero, M., Vidal, T. A new procedure for the hydrophobization of cellulose fibre using laccase and a hydrophobic phenolic compound. Bioresource Technol., 2012, 112, 341-344.

286 Silva, C., Matamá T., Kim, S., Padrão, J., Prasetyo, E.N., Kudanga, T., Nyanhongo, G.S., Guebitz, G.M., Casal, M., Cavaco-Paulo, A. Antimicrobial and antioxidant linen via laccase-assisted grafting. React. Funct. Polym,. 2011, 71, 713-720.

287 Fillat, A., Gallardo, O., Vidal, T., Pastor, F.IJ., Díaz, P., Roncero, M.B. Enzymatic grafting of natural phenols to flax fibres: Development of antimicrobial properties. Carb. Polym., 2012, 87, 146-152.

288 Felby, C., Thygesen, L.G., Sanadi, A., Barsberg, S. Native lignin for bonding of fiber boards evaluation of bonding mechanisms in boards made from laccase-treated fibers of beech (Fagus sylvatica). Industrial Crops and Products, 2004, 20, 181-189.

${ }^{289}$ Felby, C., Hassingboe, J., Lund, M. Pilot-scale production of fiberboards made by laccase oxidized wood fibers: board properties and evidence for cross-linking of lignin. Enzyme. Microb. Tech., 2002, 31, 736-741. 
290 Schubert, M., Ruedin, P., Civardi, C., Richter, M., Hach, A., Christen, H. Laccase-catalyzed surface modification of thermo-mechanical pulp (TMP) for the production of wood fiber insulation boards using industrial process water. PLOS ONE, 2015, 10, e0128623. doi:

10.1371/journal.pone.0128623.

291 Klemm, D., Kramer, F., Moritz, S., Lindström, T., Ankerfors, M., Gray, D., Dorris, A. Nanocelluloses: A new family of nature-based materials. Angew. Chem. Int. Edit., 2011, 50, 54385466.

292 Klemm, D., Cranston, E. D., Fischer, D., Gama, M., Kedzior, S. A., Kralisch, D., Kramer, F., Kondo, T., Lindström, T., Nietzsche, S. Nanocellulose as a natural source for groundbreaking applications in materials science: Today's state. Materials Today, 2018, 21, 720-748

293 Moon, R.J., Martini, A., Nairn, J., Simonsen, J., Youngblood, J. Cellulose nanomaterials review: structure, properties and nanocomposites. Chemical Society Reviews 2011, 40.7, 3941-3994.

${ }^{294}$ Favier, V., Canova, G.R., Cavaillé J.Y., Chanzy, H., Dufresne, A., Gauthier, C. Nanocomposite materials from latex and cellulose whiskers. Polym. Advan. Technol., 1995, I, 351-355.

295 Dufresne, A. Nanocellulose: a new ageless bionanomaterial. Materials Today, 2013, 16, $220-$ 227.

296 Teeri, T.T., Brumer, H., Daniel, G., Gatenholm, P. Biomimetic engineering of cellulose-based materials. Trends Biotechnol., 2007, 25, 299-306.

297 Zhou, Q., Greffe, L., Baumann, M.J., Malmström, E., Teeri, T.T., Brumer, H. Use of xyloglucan as a molecular anchor for the elaboration of polymers from cellulose surfaces: a general route for the design of biocomposites. Macromolecules, 2005, 38, 3547-3549.

298 Oinonen, P., Areskogh, D., Henriksson, G. Enzyme catalyzed cross-linking of spruce galactoglucomannan improves its applicability in barrier films. Carb. Polym., 2013, 95, 690-696.

${ }^{299}$ Ahmed, E.M. Hydrogel: Preparation, characterization, and applications: A review. J. Adv. Res., 2015, 6, 105-121.

${ }^{300}$ Chang, C., Zhang, L. Cellulose-based hydrogels: present status and application prospects. Carb. Polym., 2011, 84, 40-53.

301 Partlow, B.P., Applegate, M.B., Omenetto, F.G., Kaplan, D.L. Dityrosine Cross-Linking in Designing Biomaterials. ACS Biomater. Sci. Eng., 2016, 2, 2108-2121.

302 Oosterveld, A., Beldman, G., Voragen, A.GJ. Oxidative cross-linking of pectic polysaccharides from sugar beet pulp. Phytochem. 2000, 328, 99-207.

303 Zaidel, D.N.A., Arnous, A., Holck, J., Meyer, A.S. Kinetics of Enzyme-Catalyzed Cross-Linking of Feruloylated Arabinan from Sugar Beet. Journal of Agricultural and Food Chemistry 2011, 59, 11598-1160.

${ }^{304}$ Sun, Z., Fridrich, B., de, Santi, A., Elangovan, S., Barta, K. Bright Side of Lignin Depolymerization: Toward New Platform Chemicals. Chem. Rev., 2018, 118, 614-678.

305 Holland, C., Perzon, A., Cassland, P.R.C., Jensen, J.P., Langebeck, B., Bandsholm Sørensen, O., Whale, E., Hepworth, D., Plaice-Inglis, R., Moestrup, $\varnothing$., Ulvskov, P., Jørgensen, B. Nanofibers 
produced from agro-industrial plant waste using entirely enzymatic pretreatments. Biomacromolecules, 2018, 20, 443-453

${ }^{306}$ Harholt, J., Bach, I.C., Lind-Bouquin, S., Nunan, K.J., Madrid, S.M., Brinch-Pedersen, H., Holm, P.B., Scheller, H.V. Generation of transgenic wheat (Triticum aestivum L.) accumulating heterologous endo-xylanase or ferulic acid esterase in the endosperm. Plant Biotechnol. J., 2010, 8, 351-362.

307 Buanafina, M.M.D.O., Langdon, T., Hauck, B., Dalton, S., Timms-Taravella, E., Morris P. Targeting expression of a fungal ferulic acid esterase to the apoplast, endoplasmic reticulum or Golgi can disrupt feruloylation of the growing cell wall and increase the biodegradability of tall fescue (Festuca arundinacea). Plant Biotechnol. J., 2010, 8, 316-331.

308 Buanafina, M.D., Fescemyer, H. Modification of esterified cell wall phenolics increases vulnerability of tall fescue to herbivory by the fall armyworm. Planta 2012, 236, 513-523.

${ }^{309}$ Balakshin, M., Capanema, E., Gracz, H., Chang, H-M., Jameel H. Quantification of lignincarbohydrate linkages with high-resolution NMR spectroscopy. Planta 2011, 233, 1097-1110.

310 Watanabe, T., Koshijima, T. Evidence for an ester linkage between lignin and glucuronic acid in lignin-carbohydrate complexes by DDQ-oxidation. Agric. Biol. Chem. 1988, 52, 2953-2955.

311 Dilokpimol, A., Mäkelä M.R., Cerullo, G., Zhou, M., Varriale, S., Gidijala, L., Brás, J.LA., Jütten, P., Piechot, A., Verhaert, R., Faraco, V., Hilden, K.S., de, Vries, R.P. Fungal glucuronoyl esterases: Genome mining based enzyme discovery and biochemical characterization. Nature Biotechnol. 2018, 40 PtB, 282-287.

312 Latha, Gandla, M., Derba-Maceluch, M., Liu, X., Gerber, L., Master, E.R., Mellerowicz, E.J., Jönsson, L.J. Expression of a fungal glucuronoyl esterase in Populus: effects on wood properties and saccharification efficiency. Phytochem. 2015, 112, 210-220.

${ }^{313}$ Tsai, A.Y., Canam, T., Gorzsás, A., Mellerowicz, E.J., Campbell, M.M., Master, E.R. . Constitutive expression of a fungal glucuronoyl esterase in Arabidopsis reveals altered cell wall composition and structure. Plant Biotechnol. J., 2012, 10, 1077-1087.

${ }^{314}$ Kubicek, C.P. The Tools - Part 3: Enzymology of Lignin Degradation. In: Fungi and Lignocellulosic Biomass (Kubicek CP ed.). John Wiley \& Sons, Inc., 99-118.

315 Mäkelä M.R., Marinovic, M., Nousiainen, P., Liwanag, A.JM., Benoit, I., Sipilä J., Hatakka, A., de, Vries, R.P., Hildén, K.S. Aromatic metabolism of filamentous fungi in relation to the presence of aromatic compounds in plant biomass. In: Advances in Applied Microbiology (Sariaslani S, Gadd GM eds.). Elsevier Inc., 63-137.

316 Silva, I.S., de, Menezes, C.R., Franciscon, E., dos, Santos, E.C., Durrant, L.R. Degradation of lignosulfonic and tannic acids by ligninolytic soil fungi cultivated under microaerobic conditions. Braz. Arch. Biol. Techn., 2010, 53, 693-699.

${ }^{317}$ Cong, B., Wang, N., Liu, S., Liu, F., Yin, X., Shen, J. Isolation, characterization and transcriptome analysis of a novel Antarctic Aspergillus sydowii strain MS-19 as a potential lignocellulosic enzyme source. BMC Microbiol., 2017, 17, 129. doi: 10.1186/s12866-017-1028-0 
318 Bi, R., Lawoko, M., Henriksson, G. Phoma herbarum, a soil fungus able to grow on natural lignin and synthetic lignin (DHP) as sole carbon source and cause lignin degradation. J. Ind. Microbiol. Biotechnol., 2016, 43, 1175-1182.

319 Woo, H.L., Hazen, T.C., Simmons, B.A., DeAngelis, K.M. Enzyme activities of aerobic lignocellulolytic bacteria isolated from wet tropical forest soils. Syst. Appl. Microbiol., 2014, 37, 60-67.

${ }^{320}$ Raj, A., Reddy, M.MK., Chandra, R., Purohit, H.J., Kapley, A. Biodegradation of kraft-lignin by Bacillus sp. isolated from sludge of pulp and paper mill. Biodegradation, 2007, 18, 783-792.

${ }^{321}$ Raj, A., Chandra, R., Reddy, M.MK., Purohit, H.J., Kapley, A. Biodegradation of kraft lignin by a newly isolated bacterial strain, Aneurinibacillus aneurinilyticus from the sludge of a pulp paper mill. World J. Microbiol. Biotechnol., 2007, 23, 793-799.

322 Akita, H., Kimura, Z., Mohd, Yusoff, M.Z., Nakashima, N., Hoshino, T. Isolation and characterization of Burkholderia sp. strain CCA53 exhibiting ligninolytic potential. Springerplus, 2016, 5, 596. doi: 10.1186/s40064-016-2237-y.

323 Tian, J.H., Pourcher, A.M., Peu, P. Isolation of bacterial strains able to metabolize lignin and lignin-related compounds. Lett. in Applied Microbiology, 2016, 63, 30-37.

324 Vasudevan, N., Mahadevan, A. Degradation of lignin and lignin derivatives by Acinetobacter sp. J. Appl. Bacteriol., 1991, 70, 169-176.

325 Billings, A.F., Fortney, J.L., Hazen, T.C., Simmons, B., Davenport, K.W., Goodwin, L., Ivanova, N., Kyrpides, N.C., Mavromatis, K., Woyke, T., DeAngelis, K.M. Genome sequence and description of the anaerobic lignin-degrading bacterium Tolumonas lignolytica sp nov. Stand. Genomic. Sci., 2015, 10, 11. doi: 10.1186/s40793-015-0100-3.

326 Numata, K., Morisaki, K. Screening of marine bacteria to synthesize polyhydroxyalkanoate from lignin: Contribution of lignin derivatives to biosynthesis by Oceanimonas doudoroffii. ACS Sustain. Chem. Eng., 2015, 3, 569-573.

327 DeAngelis, K.M., Sharma, D., Varney, R., Simmons, B., Isern, N.G., Markilllie, L.M., Nicora, C., Norbeck, A.D., Taylor, R.C., Aldrich, J.T., Robinson, E.W. Evidence supporting dissimilatory and assimilatory lignin degradation in Enterobacter lignolyticus SCF1. Front. Microbiol., 2013, 4, 280. doi: 10.3389/fmicb.2013.00280.

328 Zheng, Y., Chai, L.Y., Yang, Z.H., Zhang, H., Chen, Y.H. Characterization of a newly isolated Bacterium Pandoraea sp. B-6 capable of degrading kraft lignin. J. Cent. South Univ. T., 2013, 20, 757-763.

329 Chen, Y.H., Chai, L.Y., Zhu, Y.H., Yang, Z.H., Zheng, Y., Zhang, H. Biodegradation of kraft lignin by a bacterial strain Comamonas sp. B-9 isolated from eroded bamboo slips. J. Appl. Microbiol., 2012, 112, 900-906.

330 Hofrichter, M., Ullrich, R., Pecyna, MJ., Liers, C., Lundell, T. () New and classic families of secreted fungal heme peroxidases. Appl. Microbiol. Biotechnol., 2010, 87, 871-897

331 Ramalingam, B., Sana, B., Seayad, J., Ghadessy, F.J., Sullivan, M.B. Towards understanding of laccase-catalysed oxidative oligomerisation of dimeric lignin model compounds. RSC Advances, 2017, 7, 11951-11958. 
332 Munk, L., Andersen, M.L., Meyer, A.S. Direct rate assessment of laccase catalysed radical formation in lignin by electron paramagnetic resonance spectroscopy. Enzyme Microb. Technol., 2017, 106, 88-96.

333 Wei, D., Houtman, C.J., Kapich, A.N., Hunt, C.G., Cullen, D., Hammel, K.E. Laccase and its role in production of extracellular reactive oxygen species during wood decay by the brown rot basidiomycete Postia placenta. Appl. Environ. Microbiol., 2010, 76, 2091-2097.

334 Baldrian, P., Kolařík, M., Štursová M., Kopecký J., Valášková V., Větrovský T., Žifčáková L., Šnajdr, J., Rídl, J., Vlček Č, Voříšková J. Active and total microbial communities in forest soil are largely different and highly stratified during decomposition. ISME Journal, 2012, 6, 248-258.

335 Zhao, C., Xie, S., Pu, Y., Zhang, R., Huang, F., Ragauskas, A.J., Yuan, J.S. Synergistic enzymatic and microbial lignin conversion. Green Chemistry, 2016, 18, 1306-1312.

336 Janusz, G., Pawlik, A., Sulej, J., Swiderska-Burek, U., Jarosz-Wilkolazka, A., Paszczynski A. Lignin degradation: microorganisms, enzymes involved, genomes analysis and evolution. FEMS Microbiology Reviews, 2017, 41, 941-962. doi: 10.1093/femsre/fux049

${ }^{337}$ Wang, J.H., Feng, J.J., Jia, W.T., Chang, S., Li, S.Z., Li, Y.X.,. Lignin engineering through laccase modification: a promising field for energy plant improvement. Biotechnol. Biofuels, 2015, 8, 145. doi: 10.1186/s13068-015-0331-y.

${ }^{338}$ Eudes, A., Liang, Y., Mitra, P., Loqué, D. Lignin bioengineering. Curr. Opin. Biotech., 2014, 26, 189-198

339 Wang, P., Dudareva, N., Morgan, J.A., Chapple, C. Genetic manipulation of lignocellulosic biomass for bioenergy. Curr. Opin. Chem. Biol., 2015, 29, 32-39.

${ }^{340}$ Zhou, S., Runge, T., Karlen, S.D., Ralph, J., Gonzales-Vigil, E., Mansfield, S.D. Chemical Pulping Advantages of Zip-lignin Hybrid Poplar. ChemSusChem., 2017, 10, 3565-3573. doi:

10.1002/cssc.201701317.

341 Kim, K.H., Dutta, T., Ralph, J., Mansfield, S.D., Simmons, B.A., Singh, S. Impact of lignin polymer backbone esters on ionic liquid pretreatment of poplar. Biotechnol. Biofuels, 2017, 10, 101. doi: 10.1186/s13068-017-0784-2

342 Grabber, J.H., Hatfield, R.D., Ralph, J. Apoplastic pH and monolignol addition rate effects on lignin formation and cell wall degradability in maize. J. Agric. Food. Chem., 2003, 51, 4984-4989. ${ }^{343}$ Grabber, J.H., Hatfield, R.D. Methyl esterification divergently affects the degradability of pectic uronosyls in nonlignified and lignified maize cell walls. J. Agric. Food Chem. 2005, 53, 1546- 1549.

344 Elder, T., Berstis, L., Beckham, G.T., Crowley, M.F. Coupling and Reactions of 5-Hydroxyconiferyl Alcohol in Lignin Formation. .J Agric. Food Chem., 2016, 64, 4742-4750.

345 Eudes, A., George, A., Mukerjee, P., Kim, J.S., Pollet, B., Benke, P.I., Yang, F., Mitra, P., Sun, L., Çetinkol Ö.P. Biosynthesis and incorporation of side-chain-truncated lignin monomers to reduce lignin polymerization and enhance saccharification. Plant Biotechnol. J., 2012, 10:609-620.

346 Cai, Y., Zhang, K., Kim, H., Hou, G., Zhang, X., Yang, H., Feng, H., Miller, L., Ralph, J., Liu, C.J. Enhancing digestibility and ethanol yield of Populus wood via expression of an engineered monolignol 4-O-methyltransferase. Nature Comm., 2016, 7, 11989. doi: 10.1038/ncomms11989. 
347 Gallage, N.J., Hansen, E.H., Kannangara, R.M., Olsen, C.E., Motawia, M.S., Jørgensen, K., Holme, I., Hebelstrup, K., Grisoni, M., Møller, B.L. Vanillin formation from ferulic acid in Vanilla planifolia is catalysed by a single enzyme. Nature Comm., 2014, I, 4037. doi: 10.1038/ncomms5037.

348 Gallage, N.J., Jørgensen, K., Janfelt, C., Nielsen, A.JZ., Naake, T., Duński, E., Dalsten, L., Grisoni, M., Møller, B.L. The Intra-Cellular Localization of the Vanillin Biosynthetic Machinery in Pods of Vanilla planifolia. Plant Cell Physiol., 2018, 59, 304-318.

349 Gallage, N.J., Møller, B.L. Vanillin - Bioconversion and Bioengineering of the Most Popular Plant Flavor and Its De Novo Biosynthesis in the Vanilla Orchid. Mol. Plant, 2015, 8, 40-57.

350 Eudes, A., Dutta, T., Deng, K., Jacquet, N., Sinha, A., Benites, V.T., Baidoo, E.EK., Richel, A., Sattler, S.E., Northen, T.R., Singh, S., Simmons, B.A., Loqué D. SbCOMT (Bmr12) is involved in the biosynthesis of tricin-lignin in sorghum. PLoS One, 2017, 12, e0178160. doi:

10.1371/journal.pone.0178160.

351 Lam, P.Y., Zhu, F.Y., Chan, W.L., Liu, H., Lo, C. Cytochrome P450 9361 Is a Flavone Synthase II That Channels Flavanones to the Biosynthesis of Tricin O-Linked Conjugates in Rice. Plant Physiol., 2014, 165, 1315-1327.

352 Lam, P.Y., Liu, H., Lo, C. Completion of Tricin Biosynthesis Pathway in Rice: Cytochrome P450 75B4 Is a Unique Chrysoeriol 5'-Hydroxylase. Plant Physiol., 2015, 168, 1527-1536.

353 Eloy, N.B., Voorend, W., Lan, W., Saleme, M.L., Cesarino, I., Vanholme, R., Smith, R.A., Goeminne, G., Pallidis, A., Morreel, K., Nicomedes, J Jr, Ralph, J., Boerjan, W. Silencing CHALCONE SYNTHASE in Maize Impedes the Incorporation of Tricin into Lignin and Increases Lignin Content. Plant Physiol., 2017, 173, 998-1016.

${ }^{354} \mathrm{Li}, \mathrm{M} ., \mathrm{Pu}, \mathrm{Y}$. , Ragauskas, A.J. Current understanding of the correlation of lignin structure with biomass recalcitrance. Front Chem., 2016, 4, 45. doi: 0.3389/fchem.2016.00045.

355 Sibout, R., Eudes, A., Mouille, G., Pollet, B., Lapierre, C., Jouanin, L., Séguin, A. CINNAMYL ALCOHOL DEHYDROGENASE-C and -D are the primary genes involved in lignin biosynthesis in the floral stem of Arabidopsis. Plant Cell, 2005, 17, 2059-2207.

${ }^{356}$ Van, Acker, R., Déjardin, A., Desmet, S., Hoengenaert, L., Vanholme, R., Morreel, K., Laurans, F., Kim, H., Santoro, N., Foster, C., Goeminne, G., Legee, F., Lapierre, C., Pilate, G., Ralph, J., Boerjan, W.A. Different metabolic routes for coniferaldehyde and sinapaldehyde with CINNAMYL ALCOHOL DEHYDROGENASE1 deficiency. Plant Physiol., 2017, 1, doi: 10.1104/pp.17.00834.

357 Carmona, C., Langan, P., Smith, J.C., Petridis, L. Why genetic modification of lignin leads to lowrecalcitrance biomass. Phys. Chem. Chem. Phys., 2015, 17, 358-364.

358 Shi, J., Pattathil, S., Ramakrishnan, P., Anderson, N., Im, Kim, J., Venkatachalam, S., Hahn, M.G., Chapple, C., Simmons, B.A., Singh, S. Impact of engineered lignin composition on biomass recalcitrance and ionic liquid pretreatment efficiency. Green Chem., 2016, 18, 4884-4895. 359 Chen, F., Dixon, R.A. Lignin modification improves fermentable sugar yields for biofuel production. Nature Biotechnol., 2007, 25, 759-761.

360 Johnson, A.M., Kim, H., Ralph, J., Mansfield, S.D. Natural acetylation impacts carbohydrate recovery during deconstruction of Populus trichocarpa wood. Biotechnol. Biofuels, 2017, 10, 48. doi: 10.1186/s13068-017-0734-z. 
${ }^{361}$ Tsuji, Y , Vanholme, R, Tobimatsu, Y , Ishikawa, Y, Foster, C.E , Kamimura, N , Hishiyama, S, Hashimoto, S, Shino, A, Hara, H , Sato-Izawa, K, Oyarce, P, Goeminne, G, Morreel, K, Kikuchi, J, Takano, T , Fukuda, M , Katayama, Y, Boerjan, W , Ralph, J , Masai, E, Kajita, S. Introduction of chemically labile substructures into Arabidopsis lignin through the use of LigD the Cdehydrogenase from Sphingobium sp strain SYK-6. Plant Biotech. J., 2015, 13, 821-832.

362 Mnich, E., Vanholme, R., Oyarce, P., Liu, S., Lu, F., Goeminne, G., Jørgensen, B., Motawie, M.S., Boerjan, W., Ralph, J., Ulvskov, P., Møller, B.L., Bjarnholt, N., Harholt, J. Degradation of lignin - aryl ether units in Arabidopsis thaliana expressing LigD, LigF and LigG from Sphingomonas paucimobilis SYK-6. Plant Biotech. J., 2017, 15, 581-593.

363 Masai, E., Ichimura, A., Sato, Y., Miyauchi, K., Katayama, Y., Fukuda, M. . Roles of the Enantioselective Glutathione S-Transferases in Cleavage of $\beta$-Aryl Ether. J. Bacteriol., 2003, 185, 1768-1775.

364 Dixon, D.P., Edwards, R.,. Roles for stress-inducible Lambda glutathione transferases in flavonoid metabolism in plants as identified by ligand fishing. J. Biol. Chem., 2010, 285, 3632236329.

365 Lallement, P.A., Meux, E., Gualberto, J.M., Prosper, P., Didierjean, C., Saul, F., Haouz, A., Rouhier, N., Hecker, A. Structural and enzymatic insights into Lambda glutathione transferases from Populus trichocarpa, monomeric enzymes constituting an early divergent class specific to terrestrial plants. Biochem. J., 2014, 462, 39-52.

${ }^{366}$ Bjarnholt, N. , Neilson, E. H., Crocoll, C. , Jørgensen, K. , Motawia, M. S., Olsen, C. E., Dixon, D. P., Edwards, R. and Møller, B. L. Glutathione transferases catalyze recycling of auto-toxic cyanogenic glucosides in sorghum. Plant Journal, 2018, 94: 1109-1125

${ }^{367}$ Flury, T., Wagner, E., and Kreuz, K. An inducible glutathione S-transferase in soybean hypocotyl is localized in the apoplast. Plant Physiol., 1996, 112:1185-1190.

368 Ohkama-Ohtsu, N., Radwan, S., Peterson, A., Zhao, P., Badr, A.F., Xiang, C.B., Oliver, D.J. Characterization of the extracellular gamma-glutamyl transpeptidases, GGT1 and GGT2, in Arabidopsis. Plant J., 2007, 49, 865-877.

369 Sharova, E.I., Medvedev, S.S Redox reactions in apoplast of growing cells. Russian Journal of Plant Physiol., 2017, 64: 1-14.

370 Trentin, A.R., Pivato, M., Mehdi, S.M.M., Barnabas, L.E., Giaretta, S., Fabrega-Prats, M., Prasad, D., Arrigoni, G., Masi, A. Proteome readjustments in the apoplastic space of Arabidopsis thaliana ggt1 mutant leaves exposed to UV-B radiation. Front. Plant Sci., 2015, 6, 128. doi:

10.3389/fpls.2015.00128.

371 Tolin, S., Arrigoni, G., Trentin, A.R., Veljovic-Jovanovic, S., Pivato, M., Zechman, B., and Masi, A. Biochemical and quantitative proteomics investigations in Arabidopsis ggt1 mutant leaves reveal a role for the gamma-glutamyl cycle in plant's adaptation to environment. Proteomics, 2013, 13:2031-2045.

372 Vanacker, H., Carver, T.L.W., Foyer, C.H. Pathogen-induced changes in the antioxidant status of the apoplast in barley leaves. Plant Physiol., 1998, 117:1103-1114. 
${ }^{373}$ Reiter, J., Strittmatter, H., Wiemann, L.O., Schieder, D., Sieber, V. Enzymatic cleavage of lignin $\beta-0-4$ aryl ether bonds via net internal hydrogen transfer. Green Chem., 2013, 15, 1373-1381.

${ }^{374}$ Helmich, K.E., Pereira, J.H., Gall, D.L., Heins, R.A., McAndrew, R.P., Bingman, C., Deng, K., Holland, K.C., Noguera, D.R., Simmons, B.A., Sale, K.L., Ralph, J., Donohue, T.J., Adams, P.D., Phillips, G.N. Jr. Structural Basis of Stereospecificity in the Bacterial Enzymatic Cleavage of $\beta$-Aryl Ether Bonds in Lignin. J. Biol. Chem., 2016, 291, 5234-5246

375 Rosini, E., Allegretti, C., Melis, R., Cerioli, L., Conti, G., Pollegioni, L., D'Arrigo, P. Cascade enzymatic cleavage of the beta-O-4 linkage in a lignin model compound. Catal. Sci. Technol., 2016, 6, 2195-2205.

${ }^{376}$ Kamimura, N., Takahashi, K., Mori, K., Araki, T., Fujita, M., Higuchi, Y., Masai, E. Bacterial Catabolism of Lignin-Derived Aromatics: New Findings in a Recent Decade. Environ. Microbiol. Rep., 2017, 6, 679-705.

377 Gall, D.L., Ralph, J., Donohue, T.J., Noguera, D.R. A Group of Sequence-Related Sphingomonad Enzymes Catalyzes Cleavage of $\beta$-Aryl Ether Linkages in Lignin $\beta$-Guaiacyl and $\beta$-Syringyl Ether Dimers. Environ. Sci. Technol., 2014, 48, 12454-12463.

378Picart, P., Müller, C., Mottweiler, J., Wiermans, L., Bolm, C., de, María, P.D., Schallmey, A. From gene towards selective biomass valorization: Bacterial BETA-etherases with catalytic activity on lignin-like polymers. ChemSusChem., 2014, 7, 3164-3171.

${ }^{379}$ Christensen, U., Alonso-Simon, A., Scheller, H. V, Willats, W.G.T., Harholt, J. Characterization of the primary cell walls of seedlings of Brachypodium distachyon-a potential model plant for temperate grasses. Phytochem. 2010, 71, 62-69.

380 Waldron, K.W., Parr, A.J., Ng, A., Ralph, J. Cell Wall Esterified Phenolic Dimers: Identification and Quantification by Reverse Phase High Performance Liquid Chromatography and Diode Array Detection. Phytochem. Anal., 1996, 7, 305-312. 


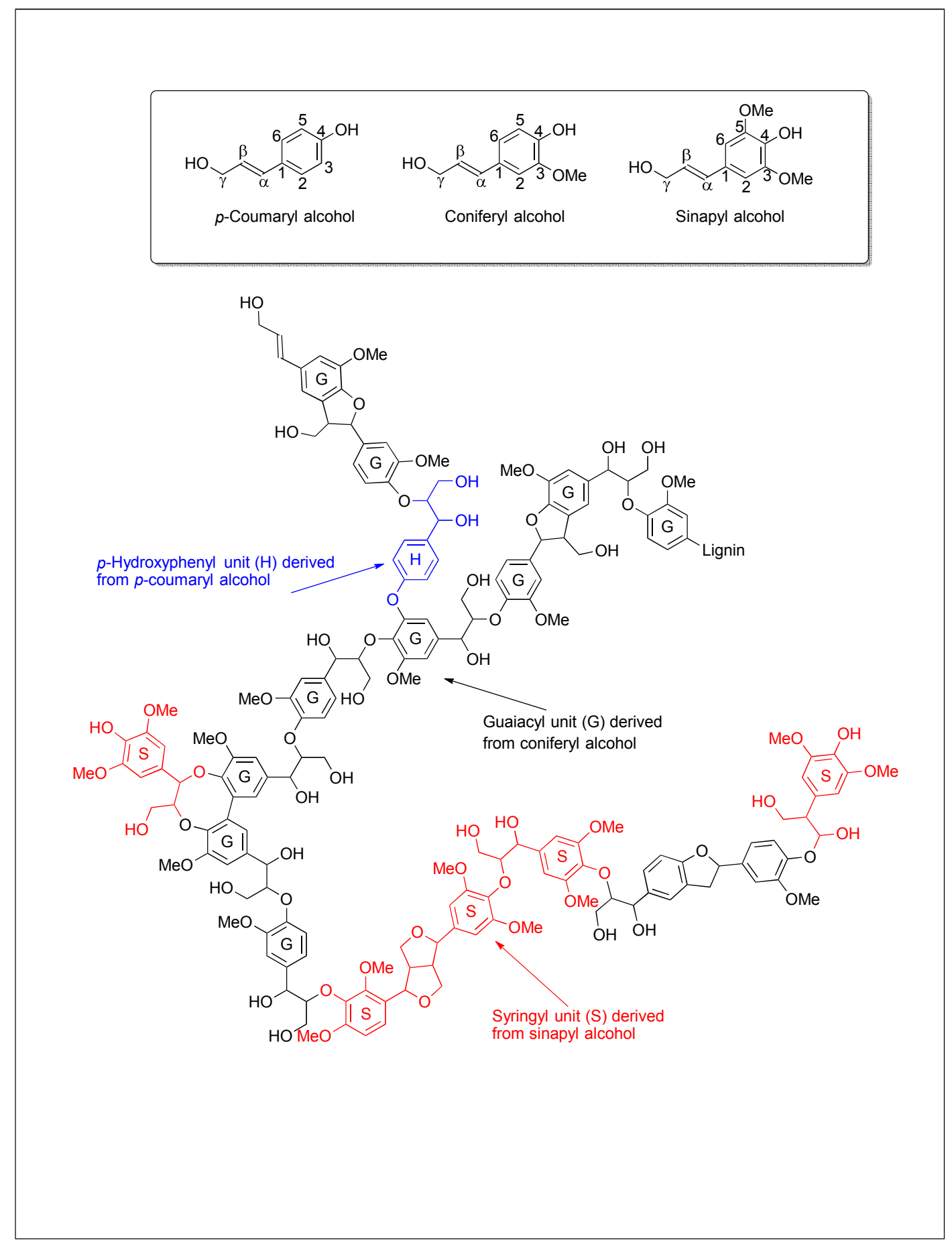


<smiles>OCC=Cc1ccc(O)cc1</smiles>

p-Coumaryl alcohol<smiles>COc1cc(/C=C/C=C/C(O)O)ccc1O</smiles>

Coniferyl alcohol<smiles>COc1cc(/C=C/C(O)I)cc(OC)c1O</smiles>

Sinapyl alcohol<smiles>[R]c1cc(C(O)C(CO)Oc2c(OC)cc(Cl)cc2OC)cc(OC)c1OCI</smiles>

aryl $\alpha$-aryl ether ( $\left.\alpha-0-4^{\prime}\right)$<smiles>[R]c1cc(C2Oc3c(OC)cc(I)cc3-c3cc(I)cc(OC)c3OC(CO)O2)cc(OC)c1OC</smiles>

dibenzodioxocin $\left.\stackrel{4}{4}-5^{\prime} / 4-O-\beta^{\prime \prime} / 4^{\prime}-O-\alpha "\right)$

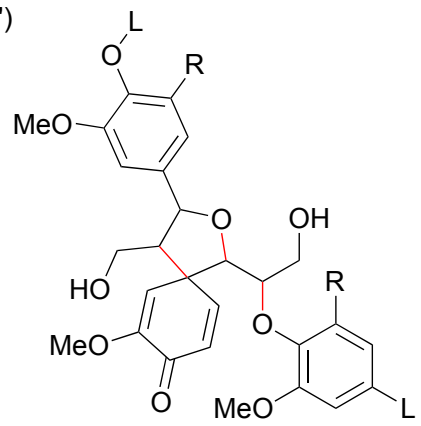

$\mathrm{R}=\mathrm{H}$ or $\mathrm{OMe}$

$\mathrm{L}=$ Lignin backbone<smiles>[R]c1cc(C2Oc3c(OC)cc(I)cc3C2CO)cc(OC)c1O[Tl]</smiles>
phenylcoumaran ( $\left.\beta-5^{\prime} / \alpha-O-4^{\prime}\right)$<smiles>[R]c1cc(I)cc(OC)c1Oc1cc(I)cc(OC)c1O</smiles>
spirodienone $\left(\beta^{7}-1^{\prime} / \alpha-O-\alpha^{\prime} / \beta^{\prime}-O-4 "\right)$<smiles>COc1cc(I)cc(-c2cc(I)cc(OC)c2O)c1O</smiles>

3

biphenyl (5-5')<smiles>[R]c1cc(C2OCC3C(c4cc([R])c(OC)c(OC)c4)OCC23)cc(OC)c1OC</smiles>

resinol $\left(\beta-\beta^{\prime} / \alpha-O-\gamma^{\prime} / \alpha^{\prime}-\mathrm{O}-\gamma\right)$ 
RSC Author Templates - ChemDraw (CDX) - Single Column Artwork Natural Product Reports Page 98 of 108

All text and images must be placed within the frame.

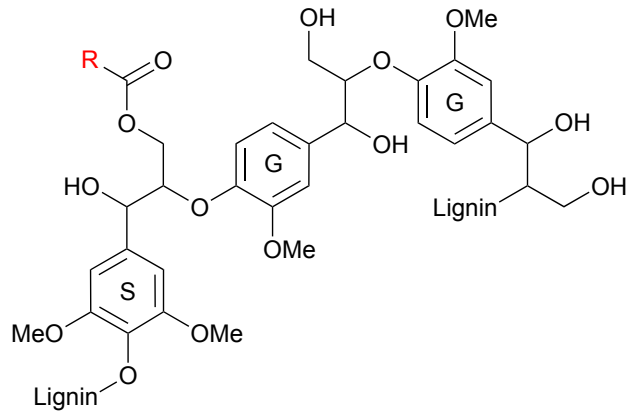

$\mathrm{R}=$

9

$-\mathrm{CH}_{3}$

10

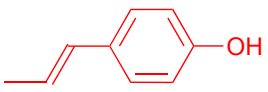

11

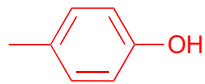

12

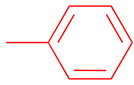

13

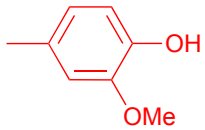

14

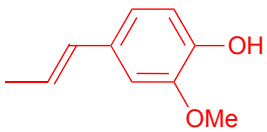




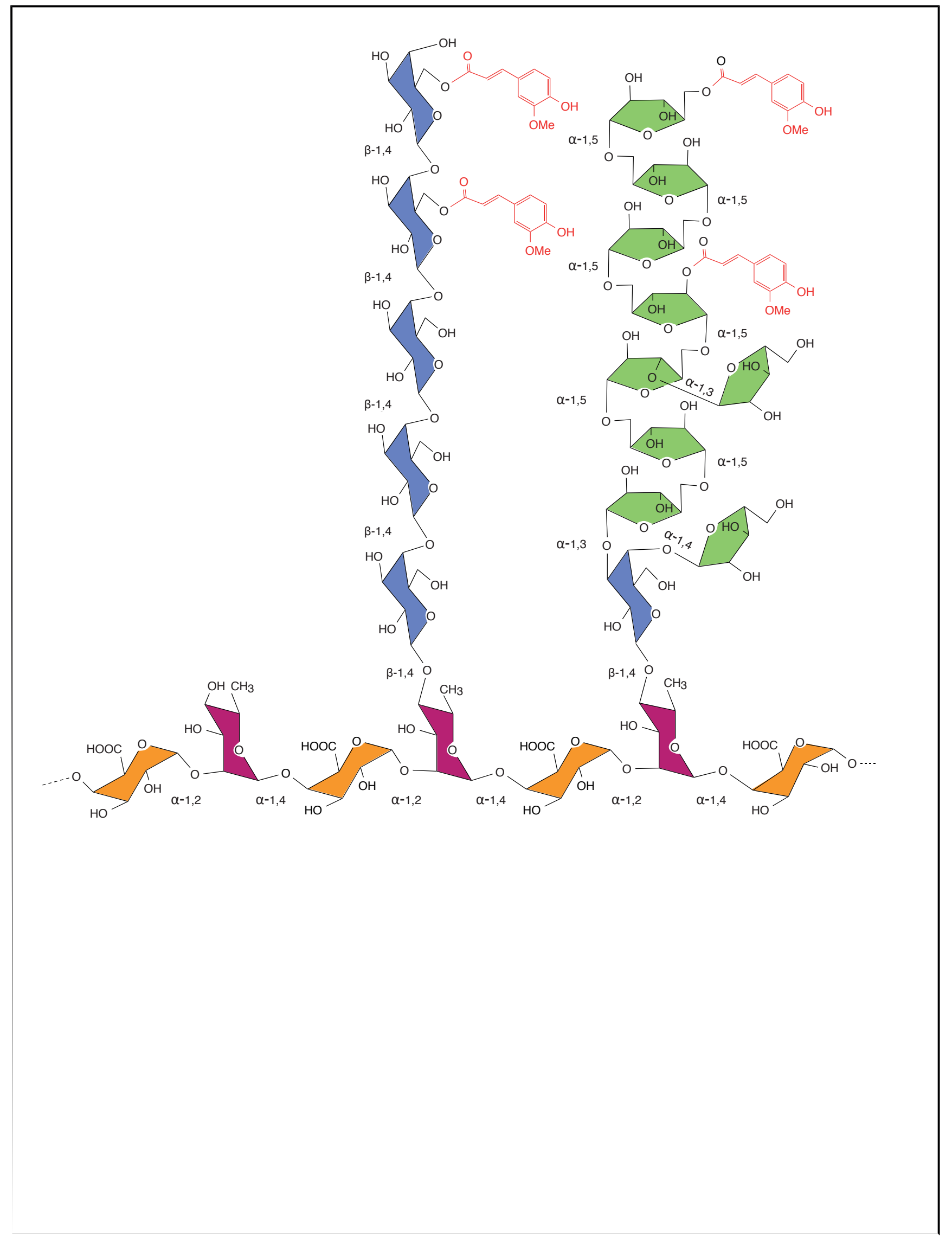


RSC Author Templates - ChemDraw (CDX) - Double Column Artwork

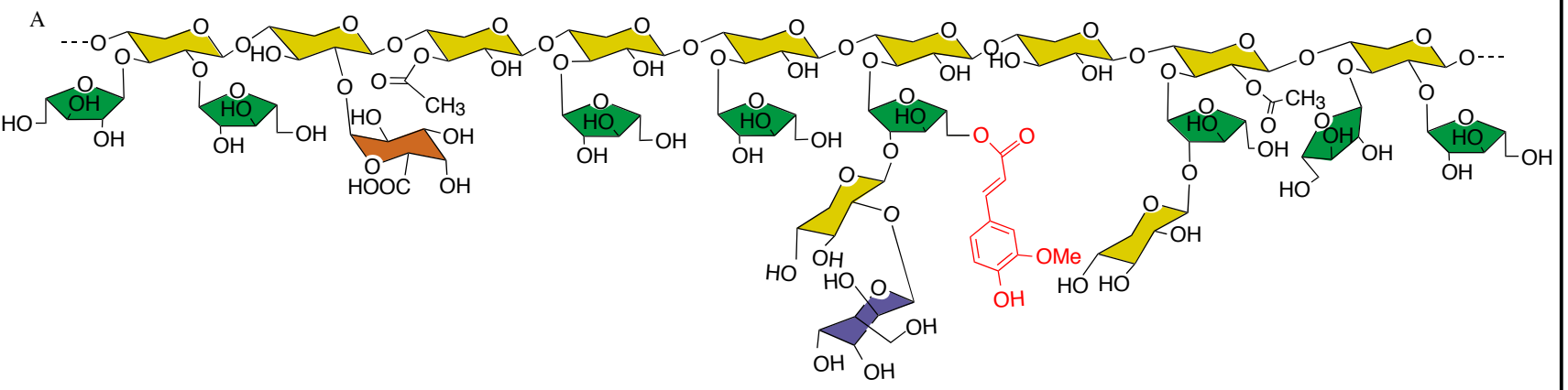

B
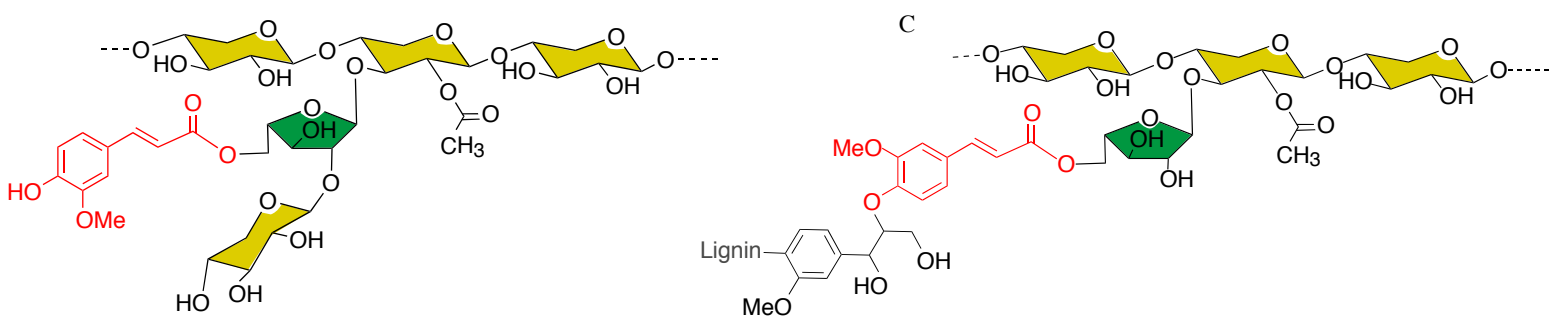
All text and images must be placed within the frame.

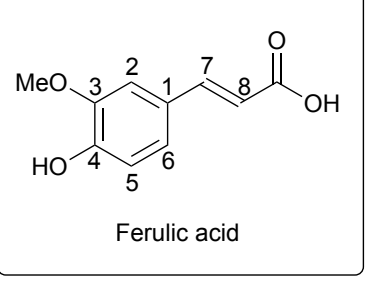

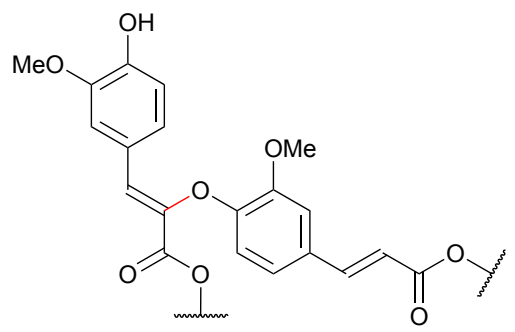

15

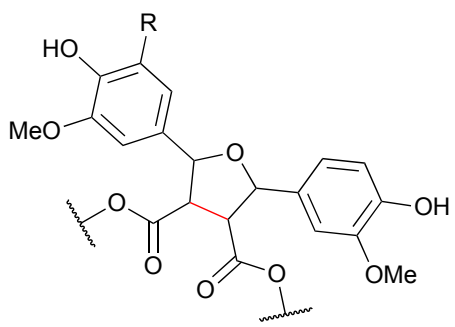

18<smiles>COc1cc(C2Oc3c(OC)cc(/C=C/C(=O)OC(C)C)cc3C2C(=O)OC(C)(C)C)ccc1O</smiles>

16<smiles>COc1cc(C=C(C(=O)OC(C)C)C(=Cc2ccc(O)c(OC)c2)C(=O)OC(C)(C)C)ccc1O</smiles>

17<smiles>COc1cc(/C=C/C(=O)OC(C)C)cc(-c2cc(/C=C/C(=O)OC(C)C)cc(OC)c2O)c1O</smiles>

20

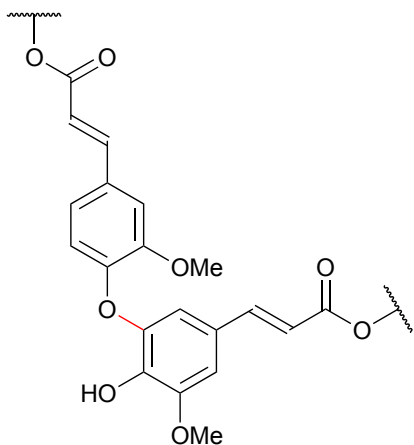

21<smiles>COc1cc(C2c3cc(OC)c(O)cc3C=C(C(=O)OC(C)C)C2C(=O)OC(C)C)ccc1O</smiles>

19<smiles>COc1cc(C2Oc3c(OC)cc(/C=C(/Oc4ccc(/C=C/C(=O)OC(C)C)cc4OC(C)C)C(=O)OC(C)C)cc3C2C(=O)OC(C)C)ccc1O</smiles>

22<smiles>CCOC(=O)C1=Cc2cc(OC)c(O)cc2C(c2cc(OC)c(O)c(-c3cc(/C=C/C(=O)OC(C)C)cc(OC)c3O)c2)C1C(=O)OC(C)C</smiles>

23

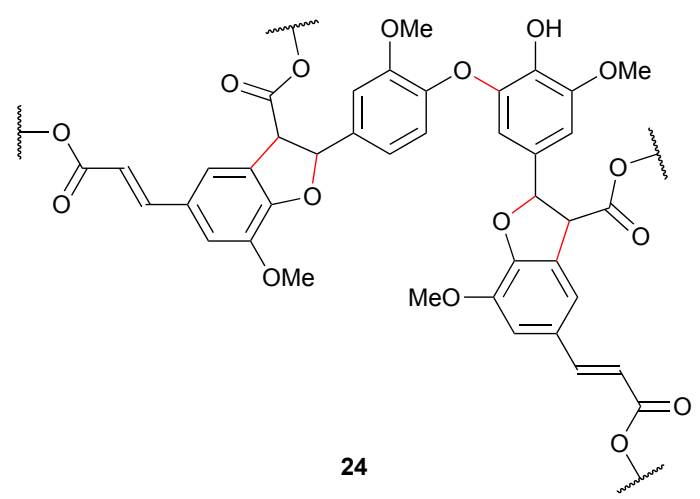




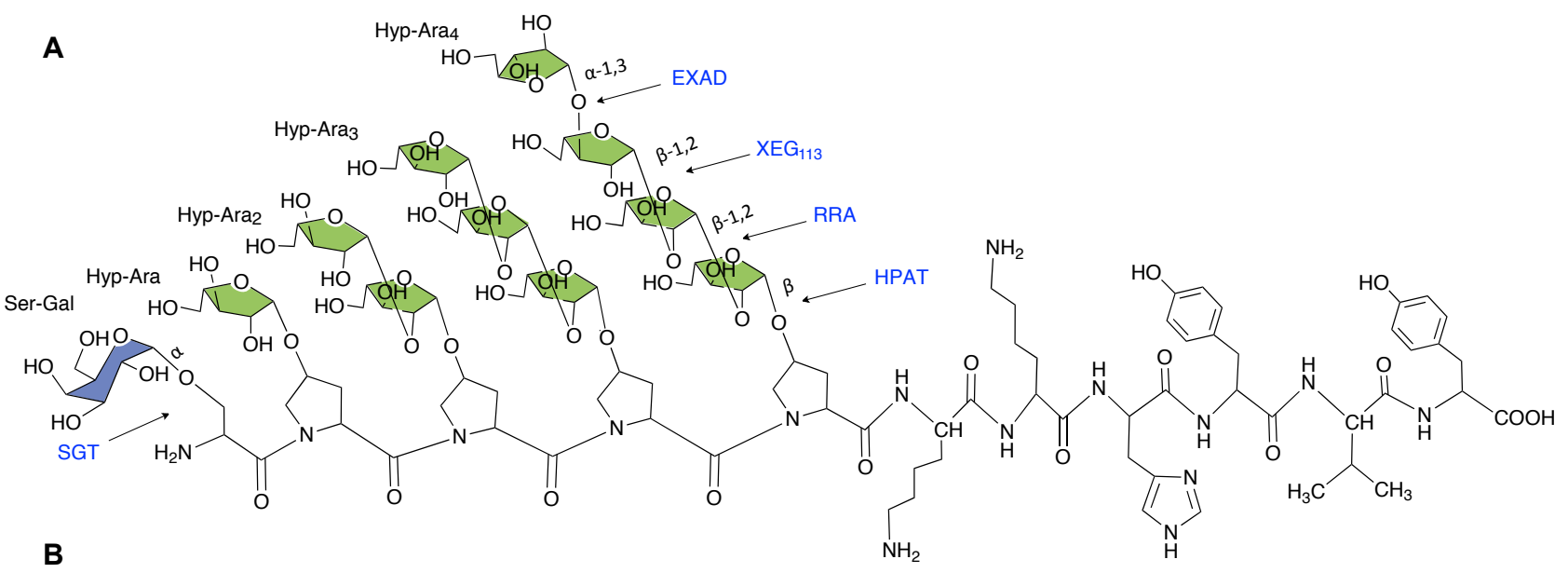

C<smiles>CNC(=O)C(C)NC</smiles> 
RSC Author Templates - ChemDraw (CDX) - Single Column Artwork Natural Product ReportsPage 104 of 108

All text and images must be placed within the frame.

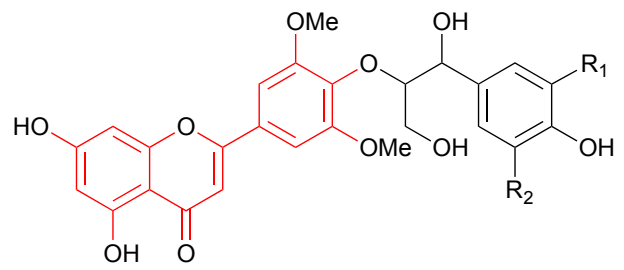

a: $R_{1}=H, R_{2}=O M e\left[T-\left(4^{\prime}-O-\beta\right)-G\right]$

b: $R_{1}=R_{2}=O M e\left[T-\left(4^{\prime}-O-\beta\right)-S\right]$

c: $R_{1}=H, R_{2}=H\left[T-\left(4^{\prime}-O-\beta\right)-H P\right]$ 


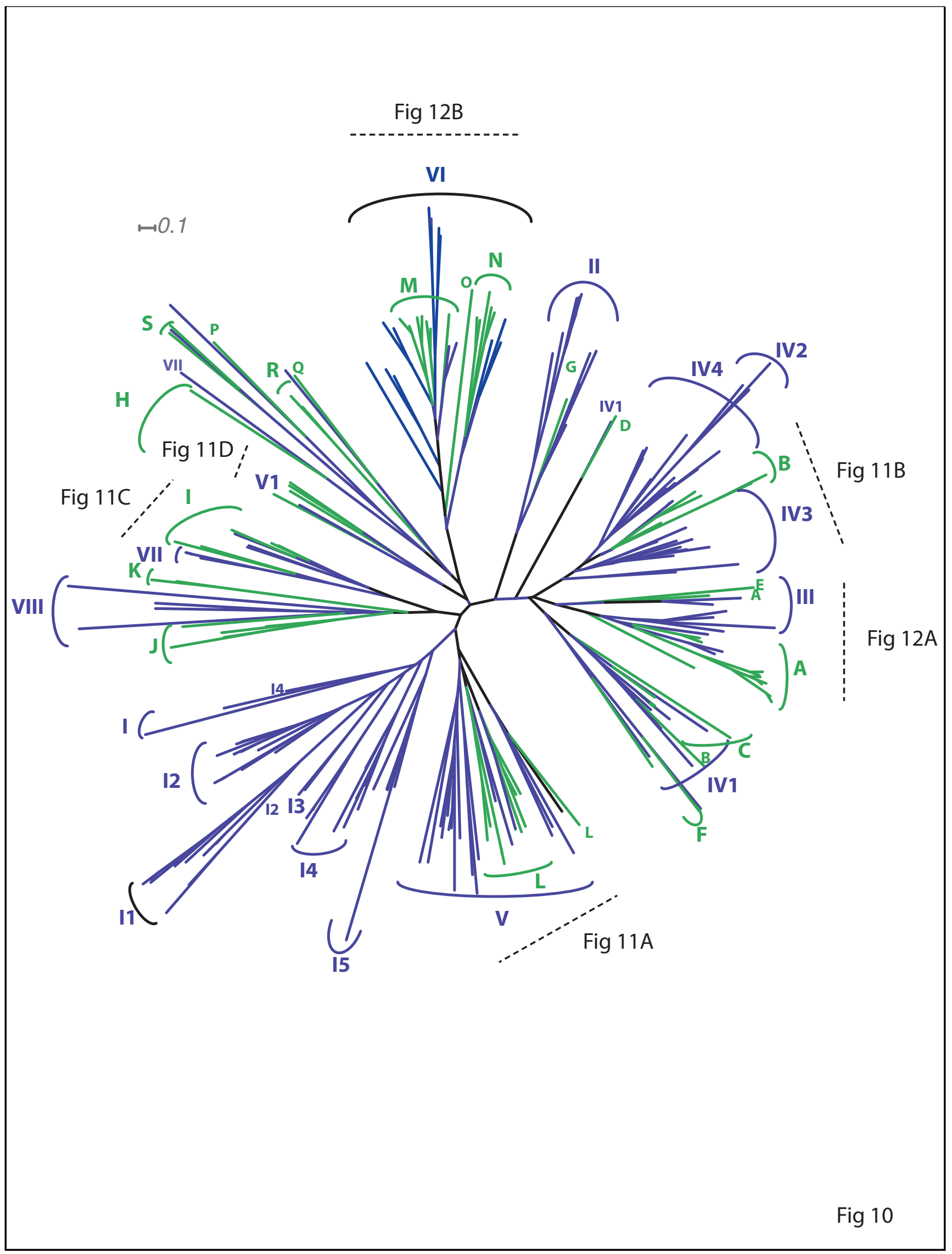


RSC Author Templates - ChemDraw (CDX) - Single Column Artwork

All text and images must be placed within the frame.

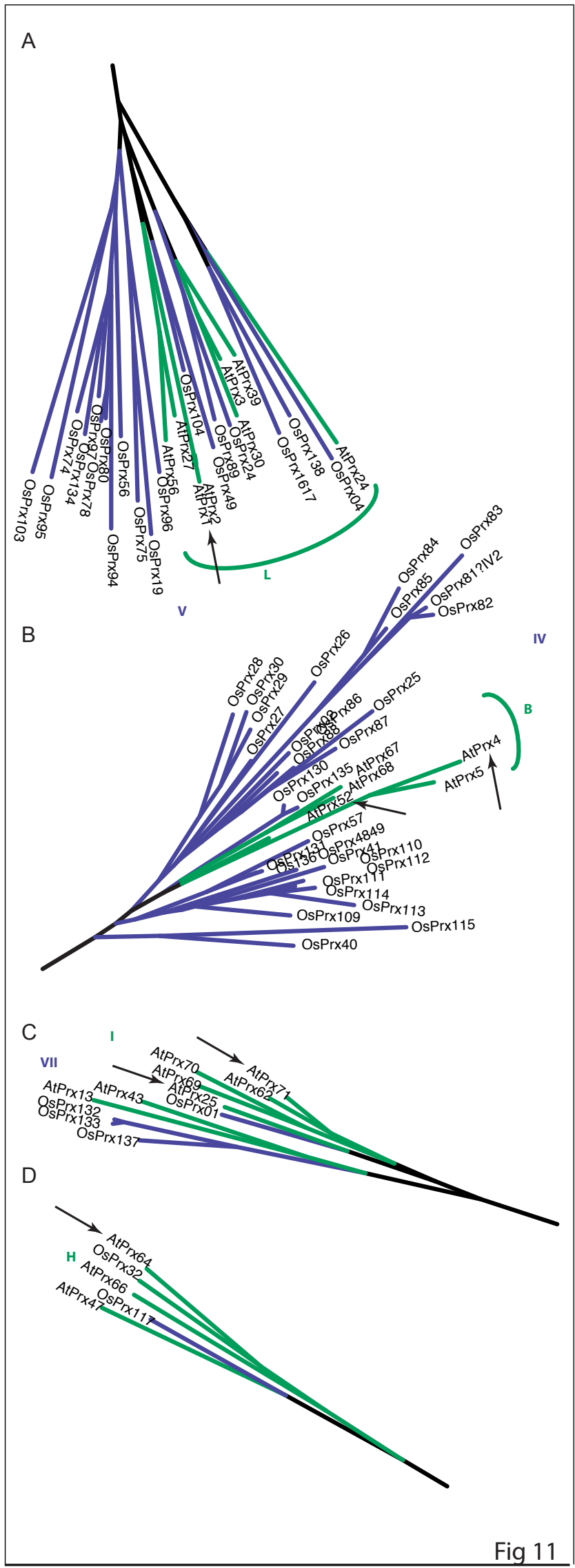


RSC Author Templates - ChemDraw (CDX) - Single Column Artwork

All text and images must be placed within the frame.

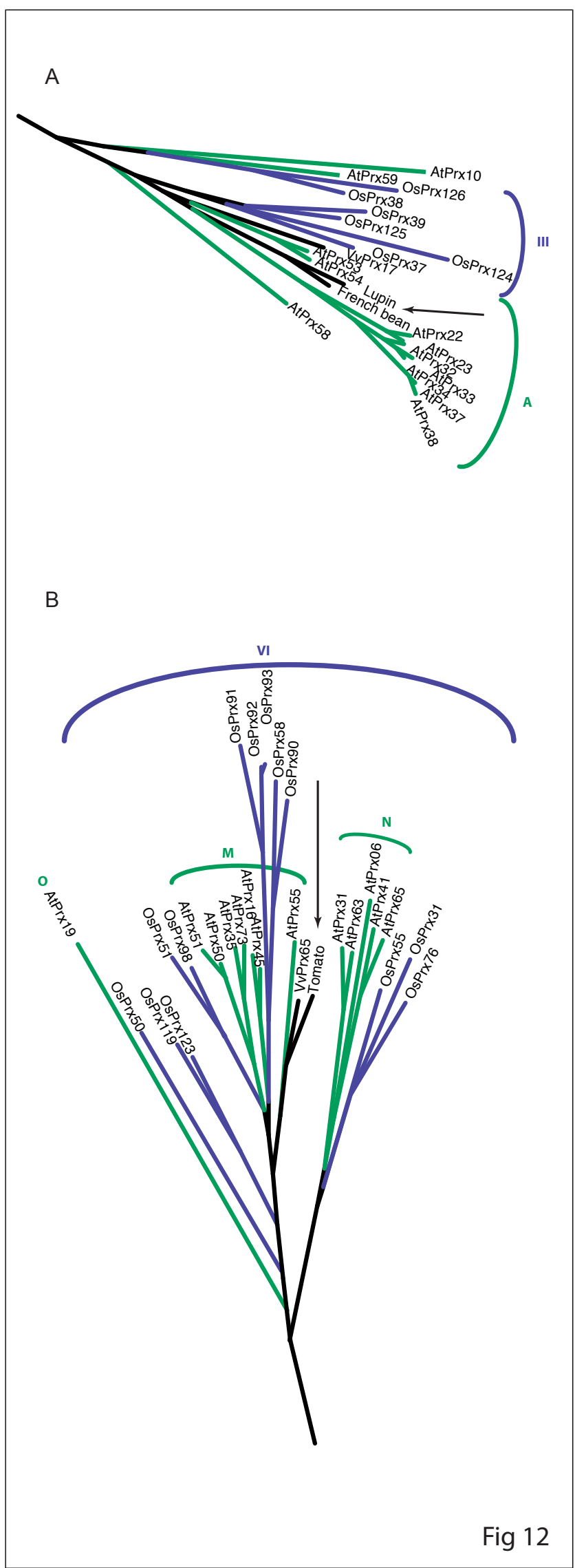


All text and images must be placed within the frame.

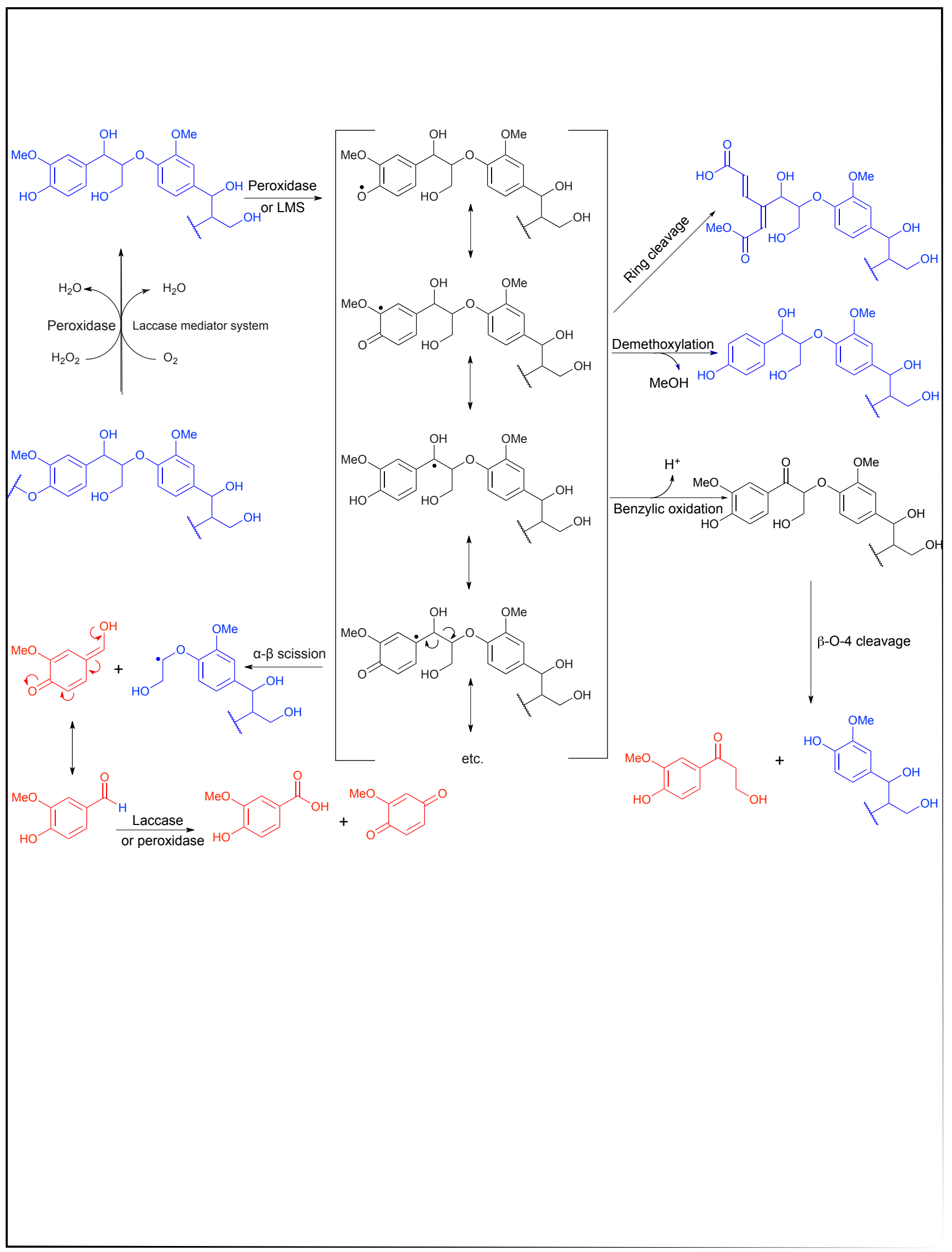


RSC Author Templates - ChemDraw (CDX) - Single Column Artwork

All text and images must be placed within the frame.<smiles>COc1cc(C(O)C(CO)Oc2ccccc2OC)ccc1O</smiles>

guaiacylglycerol- $\beta$-guaiacyl ether
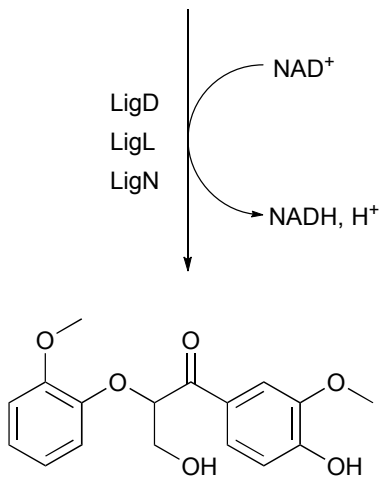

$\alpha$-(2-methoxyphenoxy)- $\beta$-hydroxypropio-vanillone

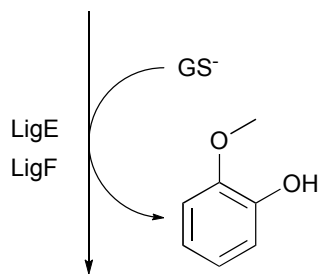<smiles>COc1cc(C(=O)C([As])CO)ccc1O</smiles>

$\alpha$-glutathionyl- $\beta$-hydroxypropiovanillone

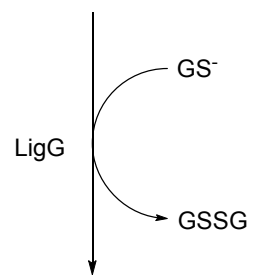<smiles>CCOc1cc(C(=O)CCO)ccc1O</smiles>

$\beta$-hydroxypropiovanillone 